Prepared in cooperation with the North Dakota State Water Commission

2009 Spring Floods in North Dakota, Western Minnesota, and Northeastern South Dakota

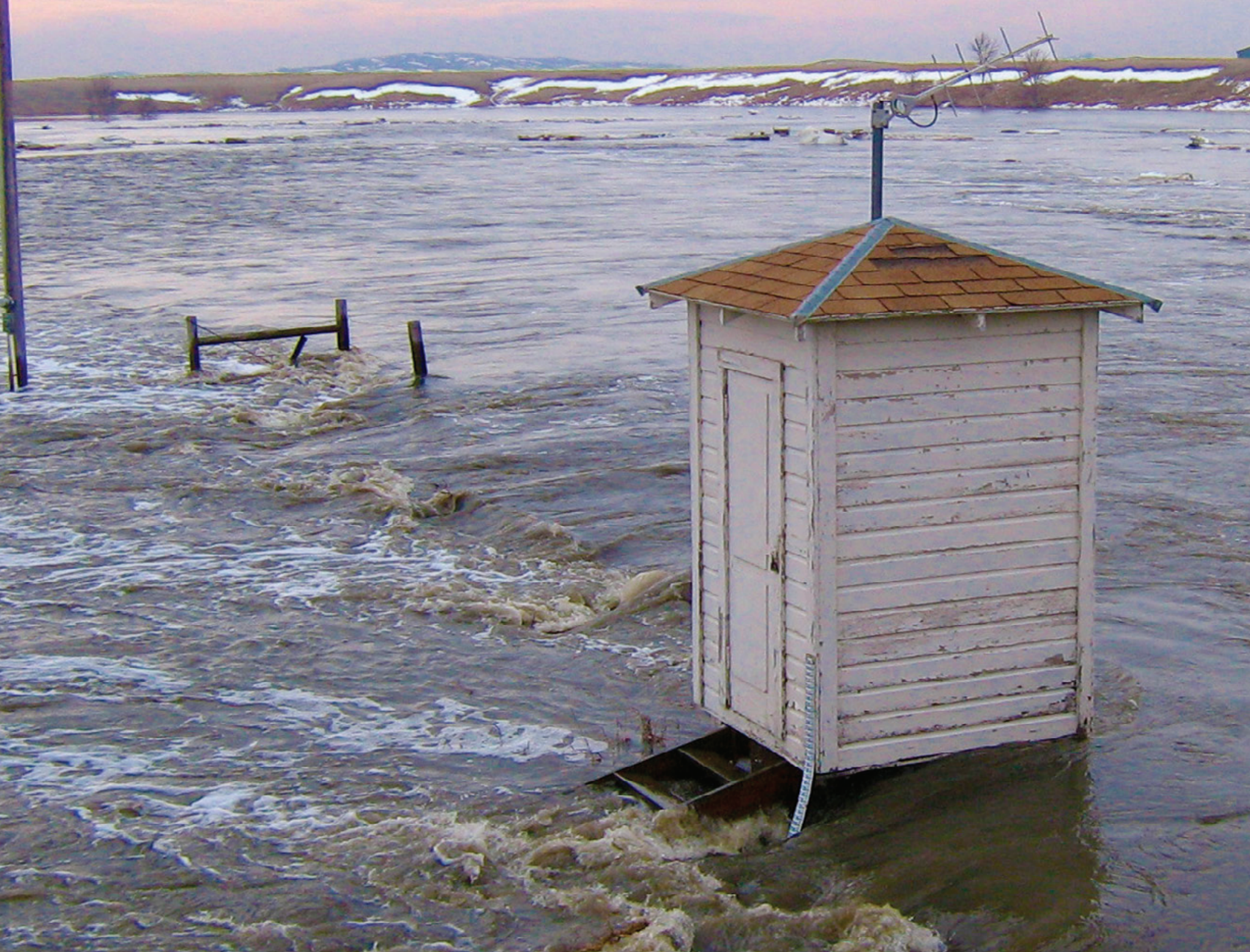

Scientific Investigations Report $2010-5225$

U.S. Department of the Interior

U.S. Geological Survey 
Cover. Streamgage at Cedar Creek near Haynes, North Dakota on March 22, 2009 (fig. 2, site 33). Photograph by U.S. Geological Survey personnel. 


\section{Spring Floods in North Dakota, Western Minnesota, and Northeastern South Dakota}

By Kathleen M. Macek-Rowland and Tara A. Gross

Prepared in cooperation with the North Dakota State Water Commission

Scientific Investigations Report 2010-5225 


\section{U.S. Department of the Interior \\ KEN SALAZAR, Secretary \\ U.S. Geological Survey \\ Marcia K. McNutt, Director}

\section{U.S. Geological Survey, Reston, Virginia: 2011}

For more information on the USGS — the Federal source for science about the Earth, its natural and living resources, natural hazards, and the environment, visit http://www.usgs.gov or call 1-888-ASK-USGS.

For an overview of USGS information products, including maps, imagery, and publications, visit http://www.usgs.gov/pubprod

Any use of trade, product, or firm names is for descriptive purposes only and does not imply endorsement by the U.S. Government.

Although this report is in the public domain, permission must be secured from the individual copyright owners to reproduce any copyrighted materials contained within this report.

Suggested citation:

Macek-Rowland, K.M., and Gross, T.A., 2011, 2009 Spring floods in North Dakota, western Minnesota, and northeastern South Dakota: U.S. Geological Survey Scientific Investigations Report 2010-5225, 41 p. 


\section{Contents}

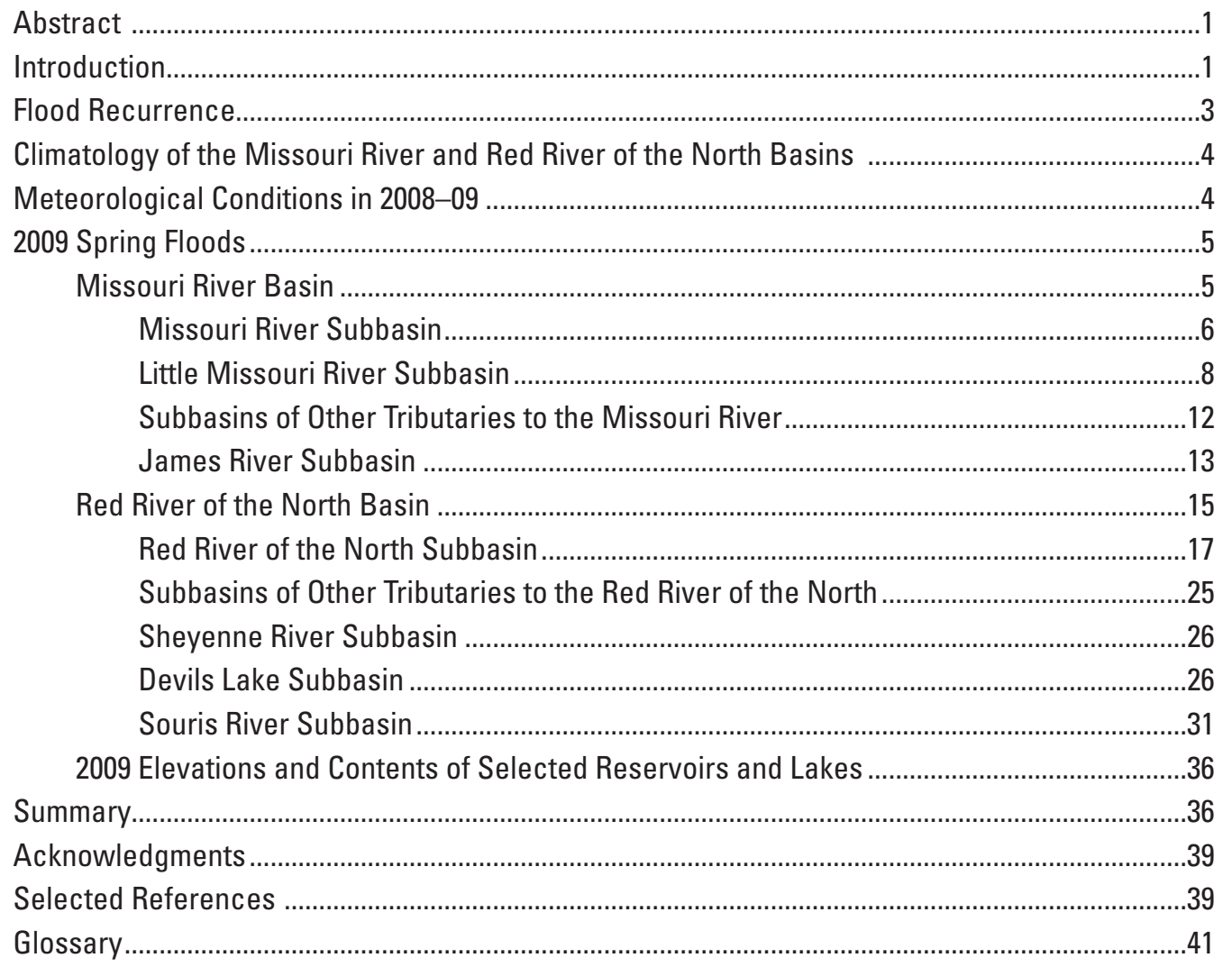




\section{Figures}

1. Map showing selected river subbasins in North Dakota, western Minnesota, and northeastern South Dakota ......

2. Map showing locations of selected streamgages, rivers, streams, lakes, and cities in the Missouri River subbasin in North Dakota .

3. Map showing ecoregions of North Dakota, Minnesota, and South Dakota.......................8

4. Map showing locations of selected streamgages, rivers, streams, lakes, and cities in the James River subbasin in North Dakota and northeastern South Dakota

5. Map showing locations of selected streamgages, rivers, streams, lakes, and cities in the Red River of the North subbasin in North Dakota, western Minnesota, and northeastern South Dakota..

6. Website hydrograph of the Red River of the North at Fargo, North Dakota, spring 2009

7. Map showing locations of selected streamgages, rivers, streams, lakes, and cities in the Sheyenne River subbasin in North Dakota

8. Map showing locations of selected streamgages, rivers, lakes, streams, lakes, and cities in the Devils Lake subbasin in North Dakota

9. Map showing locations of selected streamgages, rivers, lakes, streams, lakes, and cities in the Souris River subbasin in North Dakota

10. Map showing locations of selected reservoirs and lakes in the Missouri River and Red River of the North subbasins in North Dakota, western Minnesota, and northeastern South Dakota.

\section{Tables}

1. Recurrence intervals and the corresponding annual exceedence probability. .4

2. Record of daily snowfall totals for Bismarck, North Dakota, for 2008-09 winter...

3. Snowfall totals for selected cities or towns in the Missouri River and Red River of the North subbasins in North Dakota, western Minnesota, and northeastern South Dakota, for 1997 and 2008-09.

4. Historical and 2009 peak of record stages and discharges for the Missouri River subbasin in North Dakota.

5. Historical and 2009 peak of record stages and discharges for the James

River subbasin in North Dakota

6. Historical and 2009 peak of record stages and discharges for the Red River of the North subbasin in North Dakota, western Minnesota, and northeastern South Dakota

7. Historical and 2009 peak of record stages and discharges for the Sheyenne River subbasin in North Dakota.

8. Historical and 2009 peak of record stages and discharges for the Devils Lake subbasin in North Dakota

9. Historical and 2009 peak of record stages and discharges for the Souris River subbasin in North Dakota

10. Historical, 1997, and 2009 peak elevations of selected reservoirs and lakes in the Missouri River and Red River of the North subbasins of North Dakota, western Minnesota, and northeastern South Dakota 


\section{Conversion Factors}

Inch/Pound to SI

\begin{tabular}{lcl}
\hline \multicolumn{1}{c}{ Multiply } & By & \multicolumn{1}{c}{ To obtain } \\
\hline inch (in) & Length & \\
foot (ft) & 2.54 & centimeter $(\mathrm{cm})$ \\
mile (mi) & 0.3048 & meter $(\mathrm{m})$ \\
& 1.609 & kilometer $(\mathrm{km})$ \\
\hline square mile $\left(\mathrm{mi}^{2}\right)$ & Area & \\
square mile $\left(\mathrm{mi}^{2}\right)$ & 259.0 & hectare $($ ha) \\
& 2.590 & square kilometer $\left(\mathrm{km}^{2}\right)$ \\
\hline acre-foot $($ acre- $\mathrm{ft})$ & Volume & cubic meter $\left(\mathrm{m}^{3}\right)$ \\
acre-foot $($ acre- $\mathrm{ft})$ & 1,233 & cubic hectometer $\left(\mathrm{hm}^{3}\right)$ \\
\hline & 0.001233 & \\
\hline cubic foot per second $(\mathrm{ft} / \mathrm{s})$ & Flow rate & cubic meter per second $\left(\mathrm{m}^{3} / \mathrm{s}\right)$ \\
\hline
\end{tabular}

Temperature in degrees Fahrenheit $\left({ }^{\circ} \mathrm{F}\right)$ may be converted to degrees Celsius $\left({ }^{\circ} \mathrm{C}\right)$ as follows:

${ }^{\circ} \mathrm{C}=\left({ }^{\circ} \mathrm{F}-32\right) / 1.8$

Vertical coordinate information is referenced to the National Geodetic Vertical Datum of 1929 (NGVD 29).

Horizontal coordinate information is referenced to the North American Datum of 1983 (NAD 83).

Altitude, as used in this report, refers to distance above the vertical datum. 



\title{
2009 Spring Floods in North Dakota, Western Minnesota, and Northeastern South Dakota
}

\author{
By Kathleen M. Macek-Rowland and Tara A. Gross
}

\section{Abstract}

In 2009, record-breaking snowfalls and additional spring moisture caused severe flooding in parts of the Missouri River and Red River of the North (Red River) Basins in North

Dakota, Minnesota, and South Dakota. There were 48 peak of record stages and 36 discharges recorded at U.S. Geological Survey streamgages located in both basins between March 20 and May 15, 2009. High water continued to affect many communities up and down the rivers' main stems and tributaries for nearly 2 months.

Record snowfall for single-day totals, as well as monthly totals, occurred throughout the Missouri River and Red River of the North Basins. Additional moisture in the spring as well as the timing of warmer temperatures caused record flooding in many places in both basins with many locations reporting two flood crests.

Ice jams on the Missouri River, located north and south of Bismarck, N. Dak., caused flooding. Southwest Bismarck was evacuated as rising waters first began inundating homes in low-lying areas along the river and then continued flowing into the city's lower south side. On March 24, 2009, the peak stage of the Missouri River at Bismarck, N. Dak. streamgage was 16.11 feet, which was the highest recorded stage since the completion of Garrison Dam in 1954. South of Bismarck, the Missouri River near Schmidt, N. Dak. streamgage recorded a peak stage of 24.24 feet on March 25, 2009, which surpassed the peak of record of 23.56 feet that occurred on December 9,1976 . While peak stage reached record levels at these streamgages, the discharge through the river at these locations did not reach record levels. The record high stages resulted from ice jams occurring on the Missouri River north and south of the cities of Bismarck and Mandan.

At the Red River of the North at Fargo, N. Dak. streamgage, the Red River reached a record stage of 40.84 feet surpassing the previous peak of record stage of 39.72 feet set in 1997. The associated peak streamflow of 29,500 cubic feet per second exceeded the previous peak of record set in 1997 by 1,500 cubic feet per second. For the cities of Fargo, and Moorhead, Minn., and the surrounding area, the stage of the Red River remained above flood stage for nearly 2 months.
In addition to high stage and flow on the main-stem Missouri and Red Rivers, peak of record stage and discharge were recorded at many U.S. Geological Survey streamgages in the Missouri River and Red River Basins. Several reservoirs and lakes in the region also experienced record stage elevations from the high flows during the 2009 spring snowmelt floods.

\section{Introduction}

Record flooding in the spring of 2009 occurred within the Missouri River, Little Missouri River, James River, Red River of the North, Sheyenne River, Devils Lake, and Souris River subbasins in North Dakota, western Minnesota, and northeastern South Dakota (fig. 1). Record winter snowfalls were recorded in many locations in the region and above-normal precipitation during the spring thaw caused the worst flooding since the 1997 spring floods with several communities experiencing the worst recorded flooding since European settlement in the region.

In the Missouri and Red River of the North Basins, the U.S. Geological Survey (USGS) North Dakota Water Science Center works in cooperation with many local, State, and Federal agencies and offices to collect the data included in this report. The USGS prepared a compilation of 2009 spring floods data in cooperation with North Dakota State Water Commission.

Most spring flooding in North Dakota, Minnesota, and South Dakota is caused by snowmelt, and the severity of the flooding is affected by other ancillary weather conditions including: (1) substantial precipitation in the fall that produces high levels of soil moisture; (2) above-normal snowfall in the winter; (3) moist, frozen ground that prohibits infiltration of additional moisture; (4) a late spring thaw; (5) above-normal precipitation during spring thaw, and (6) ice jams (temporary dams of ice) on rivers and streams (Macek-Rowland, 2001). Many of these conditions were present during the 2009 spring floods. Also affecting the flooding in many places within the basins are the landforms or channel conditions (or configurations). These landforms include channel depth and width, channel slope, direction of flow, and tributary effect. 


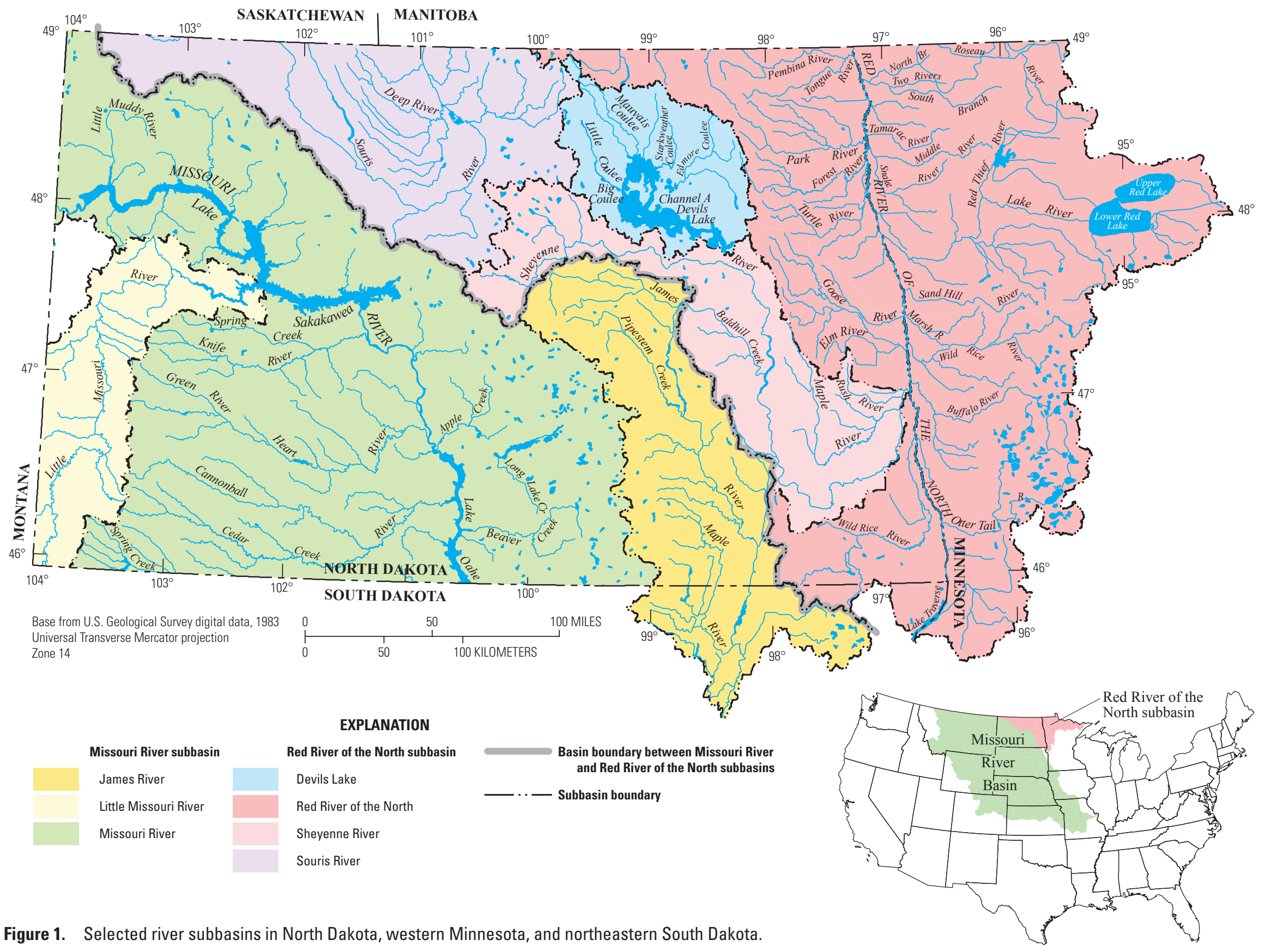


During the spring and into the summer of 2009 many USGS streamgages located in North Dakota, western Minnesota, and northeastern South Dakota recorded peak of record stages and discharges. From March 20 through May 15, 2009, many locations reported two flood crests. The two flood crests at several streamgages occurred because of additional spring rainfall on top of record winter snowfall and warm temperatures in late March. High water and adverse weather conditions continued to plague many communities up and down the rivers' main stems and tributaries for 6 to 9 weeks. In some instances, high water remained in areas for as many as 5 months before receding. The elevations in several reservoirs were at or near record stages as high flows moved through the various river basins. Several smaller dams and reservoirs were damaged when high flows topped spillways and banks (North Dakota Water Education Foundation, 2009).

In this report, the 2009 spring floods in North Dakota, western Minnesota, and northeastern South Dakota are described. Historical and 2009 peak stages, peak discharges, and the associated recurrence intervals are given for selected streamgages in the Missouri River, Little Missouri River, James River, Red River of the North, Sheyenne River, Devils Lake, and Souris River Basins (fig. 1). The peak stage and discharge data given for selected streamgages in this report are presented in downstream order (or the order of location of the streamgages on a river or stream when moving from upstream to downstream). Discharge and stage information discussed in this report are available from the USGS National Water Information System or NWIS on the internet (available at $h t t p: / /$ waterdata.usgs.gov/nwis).

Most of the estimates of flood frequency used in this report were determined using the standard guidelines and methodology in Bulletin 17B (Interagency Advisory Committee on Water Data, 1982). Estimates for flood frequency on the Red River of the North main-stem streamgages were determined by using information in a report by the U.S. Army Corps of Engineers, St. Paul District (U.S. Army Corps of Engineers, 2001). The report includes recurrence intervals for several streamgages in the Red River Basin and was produced with technical expertise from cooperators in State and Federal Agencies in the Red River Basin, including the USGS North Dakota Water Science Center, and followed the methodology of Bulletin 17B. When discussing recurrence intervals for streamgages in the Red River of the North Basin, data from that report are used.

\section{Flood Recurrence}

As part of its mission, the USGS is charged by Congress to provide unbiased data and information about the Nation's rivers and streams. The USGS works in cooperation with other local, State, and Federal agencies and offices to provide information to inform and protect the Nation's citizens and their property from floods and to help mitigate flood hazards in the future. To provide this information, the USGS operates more than 7,500 streamgages throughout the nation. In North Dakota, the USGS North Dakota Water Science Center operated approximately 150 gages (including streamgages) during the 2009 flood.

Data collected from streamgages include stream stage (height of a water surface in a stream above an established datum) and discharge (sometimes referred to as streamflow). Stream stage data may be collected continuously by instrumentation housed in special shelters (known as streamgages) next to a water body. Discharge data are collected by USGS personnel making measurements of velocities and depths in the channel near the steamgage at selected times throughout the year. During flooding, USGS personnel may be asked to make discharge measurements more often to capture the variability of high flows.

Stream stage (height of a water surface above an established datum) and discharge (sometimes referred to as streamflow) measured by USGS personnel at streamgages are used to define a rating curve. The rating curve reflects the unique relation between stage and discharge. Rating curves are used to determine what the discharge is at a particular streamgage when personnel are not present on site. During times of flooding, water-resource managers and emergency management specialists may use rating curves to help determine the extent of flooding or the amount of flow going through part of a river system at a given point in time.

The stage-discharge relation may not be well defined at extremely high discharges because these discharges are rare events of short duration and have unstable conditions that often make on-site measurement extremely difficult; therefore, estimates for some peak discharges need to be extrapolated from rating curves extended to historical peak stages.

The peak discharges recorded during flood events are used to determine the probability that a given discharge will be exceeded in the future. This probability is often expressed in recurrence intervals. For example, a flood that has a 1-percent (1 in 100) chance of exceedance in any given year would, on the long-term average, be expected to occur only about once a century. This flood would be termed a "100-year flood"; however, the chance of such a flood occurring in any given year is 1 percent. Thus, a 100-year flood can occur in successive years (or even within the same year) at the same location. Continuous periods of record at the same location are required for developing a rating curve. For determining recurrence intervals at the same location, continuous data of 10 years or more are preferred. In some instances, recurrence interval estimates can be based on periods of regulated flow or made with historic adjustments when historic data are available. Recurrence intervals for selected streamgages in the Missouri River and Red River of the North Basins are given in this report.

The USGS has determined that for some individuals the term "recurrence interval" is a confusing concept. A common misperception is that a recurrence interval defines when a flood will occur. For example, it is assumed that a recurrence interval of 100 years means once a " 100 -year flood" occurs at 
a given location, it will not happen again at that same location until 100 years have passed, which may not always be true. Floods are random processes that can occur anytime a set of antecedent conditions and meteorological conditions are right. To clarify these misperceptions, the USGS now encourages the use of the term "annual exceedance probability" (AEP) (Holmes and others, 2010).

Annual exceedance probability is the peak streamflow being characterized by its probability or chance of occurrence being equaled or exceeded in any given year. The AEP percentage is expressed as a decimal, fraction, or percentage. Equivalence of selected AEP values with the corresponding recurrence intervals are listed in table 1.

Table 1. Recurrence intervals and the corresponding annual exceedence probability.

[AEP, annual exceedence probability]

\begin{tabular}{cc}
\hline $\begin{array}{c}\text { Recurrence interval } \\
\text { (in years) }\end{array}$ & $\begin{array}{c}\text { AEP } \\
\text { (percent) }\end{array}$ \\
\hline 2 & 50 \\
5 & 20 \\
10 & 10 \\
25 & 4 \\
50 & 2 \\
100 & 1 \\
500 & 0.2 \\
\hline
\end{tabular}

\section{Climatology of the Missouri River and Red River of the North Basins}

North Dakota, Minnesota, and South Dakota have a typical continental climate characterized by warm to hot summers and very cold winters. The climatic conditions across the northern plains are caused by three main types of air masses: (1) a continental polar (dry) air mass from the north; (2) a maritime polar air mass from the northwest; and, (3) a tropical air mass that is called continental tropical (dry) if it originates from the southwest or maritime tropical (moist) if it originates from the southeast. The juxtaposition of the air masses over the region determines the amount and location of precipitation occurring in the area at any given time (U.S. Geological Survey, 1991). The amount and location of the precipitation occurring in an area determines whether flooding will occur there in a given year.

Summer precipitation is caused by thunderstorms that develop when warm, moist air that originates in the south contacts continental polar air masses moving across the region. Precipitation in the region can be enhanced when the moisture-laden air masses moving across the continent are modified to include moisture recycled through the landvegetation-air interface.

Winter precipitation as snowfall occurs when continental polar air masses move south from Canada into the northern plains and meet maritime polar or tropical air masses laden with moisture. The results are mid-latitude frontal systems that usually provide precipitation over large areas for an extended period of time. Excessive snowfall can occur when the frontal systems moving eastward stall over the region and continue to receive moisture from maritime tropical air masses moving northward (Macek-Rowland and others, 2001b).

Annual precipitation in North Dakota, western Minnesota, and northeastern South Dakota averages about 13 inches in the west to about 26 inches annually in the east (Paulson and others, 1991). Approximately 65 to 75 percent of the precipitation falls during the growing season (April through September). If successive periods of normal to much-abovenormal precipitation occur in the region, soils become nearly saturated, and numerous potholes, sloughs, and small lakes fill reducing or eliminating their capacity to retain runoff. Abovenormal precipitation occurred in North Dakota, western Minnesota, and northeastern South Dakota in the fall of 2008 resulting in above-normal soil-moisture levels in many places before the fall freeze up (North Dakota Monthly Climate Summary, October 2008, accessed January 2010 at $h t t p: / / w w w$. ndsu.edu/ndsco/publication/ndsco/summary/2008/oct.pdf; NOAA Satellite and Information Service, State Drought, October 2008, accessed January 2010 at $h t t p: / / w w w . n c d c . n o a a$. gov/img/climate/research/2008/oct/zin200810 pg.gif). These soil-moisture conditions added to the potential for severe flooding because if the soil is near saturation at fall freeze up, an impermeable layer is formed. This impermeable layer can retard or prevent any additional moisture from infiltrating into the soil during the spring thaw.

\section{Meteorological Conditions in 2008-09}

The intensity and scale of flooding in any area is greatly affected by the meteorological conditions before and during the flood event. In the region of North Dakota, Minnesota, and South Dakota flooding is usually caused by spring snowmelt or intense summer storms. The antecedent conditions before an event and the meteorological conditions before and during an event can exacerbate the size and duration of the flood.

A wet fall, snowy winter, and additional moisture in the spring set the stage for flooding in spring 2009 in North Dakota, western Minnesota, and northeast South Dakota. Several locations in these states received record snowfall in the winter of 2008-09 (North Dakota Monthly Climate Summary, March 2009, accessed January 2010 at $h t t p: / / w w w . n d s u$. edu/ndsco/publication/ndsco/summary/2009/mar.pdf; NOAA Satellite and Information Service, Snow and Ice, winter 2008/2009, accessed January 2010 at $h t t p: / / w w w . n c d c . n o a a$. gov/oa//climate/research/2008/snow0809.html\#apr). These 
snowfall totals were similar to the snowfall totals recorded for the same period in 1996-1997 when one of the worst years of spring flooding in recorded history occurred in North Dakota, western Minnesota, and northeastern South Dakota. In December 2008, monthly snowfall records were recorded at several cities in North Dakota. Fargo (fig. 1) set a record for any month at Fargo with 33.5 inches of snowfall. A snowfall record of 33.3 inches was recorded by National Weather Service office in Bismarck, making it the highest snowfall total recorded for any month in that city. Grand Forks, N. Dak. (fig. 1), received a record 30.1 inches of snowfall for December, making it the second snowiest month on record for that city.

Throughout the 2008-09 winter, several cities had one-day record snowfall totals. Bismarck, for example, had the highest daily snowfall totals for 4 days in the winter of 2008-09 (table 2).

Bismarck received 29.7 inches of snowfall in March 2009, which tied with March 1950 for the highest snowfall for that month. It also was the 5th highest amount for any month on record in that city. To the east, in Fargo, a record snowfall of 28.1 inches also was recorded for March. This total topped the previous record of 26.2 inches set in 1997.

In late March, additional moisture in the form of rainfall and warming temperatures also exacerbated the flood conditions in North Dakota and western Minnesota, particularly in the Red River Basin. In the area of Fargo and Moorhead, Minn., 2.79 inches of rainfall fell during a 5-day period from March 22 to 26, 2009 and daily temperatures were as high as $53^{\circ} \mathrm{F}$. Fargo had a record precipitation total of 4.62 inches in March 2009, topping the 1882 record of 2.83 inches (National Oceanic and Atmospheric Administration, Public Affairs forecast, written commun., February 23, 2010). Added moisture and warm temperatures at the end of March created a second crest of floodwaters at many streamflow gages in the basins.

Overall, the period of September 2008 through March 2009 was the wettest September through March period recorded for North Dakota. March 2009 was the wettest

Table 2. Record of daily snowfall totals for Bismarck, North Dakota, for 2008-09 winter.

[Data from U.S. Department of Commerce, National Oceanic and Atmospheric Administration, National Weather Service website accessed January 2011 at http://www.crh.noaa.gov/product.php? site $=$ NWS\&product $=$ CLM\&is suedby $=B I S]$

\begin{tabular}{lcc}
\hline $\begin{array}{c}\text { Date of record } \\
\text { snowfall }\end{array}$ & $\begin{array}{c}\text { Daily record } \\
\text { snowfall totals, } \\
\text { 2008-09 } \\
\text { (in inches) }\end{array}$ & $\begin{array}{c}\text { Previous record of } \\
\text { daily record totals } \\
\text { and (year) } \\
\text { (in inches) }\end{array}$ \\
\hline November 6, 2008 & 5.7 & $3.0(1901)$ \\
December 13, 2008 & 5.9 & $3.2(1909)$ \\
December 14, 2008 & 6.6 & $5.1(1994)$ \\
January 13, 2009 & 5.4 & $3.4(1967)$ \\
\hline
\end{tabular}

March in North Dakota history since recordkeeping began in 1881, almost doubling the previous record set in March 1882, and the snowiest March since 1881 for North Dakota topping the March 1997 snowfall record by 2 inches. (North Dakota State Climate Office, March 2009 report, accessed January 2010 at $h t t p: / / w w w . n d s u . e d u / n d s c o / p u b l i c a t i o n / n d s c o /$ summary/2009/mar.pdf). In 2009, North Dakota, Minnesota, and South Dakota had their fourth, sixth, and ninth wettest January-through-March periods, respectively. Snowfall totals for 1996-97 and 2008-09 for selected cities in the Missouri River and the Red River Basins are given in table 3.

\section{Spring Floods}

\section{Missouri River Basin}

The Missouri River is the largest river system in North Dakota. The river flows into North Dakota in the northwestern part of the state. Of the 529,000 square miles $\left(\mathrm{mi}^{2}\right)$ in the Missouri River Basin, 33,902 $\mathrm{mi}^{2}$ are located in North Dakota (fig. 2). The basin varies in topography from west to east. The western and southern parts of the Missouri River Basin in North Dakota are located in the Northwestern Great Plains ecoregion and are characterized by small, sharply defined valleys with scattered buttes, hills, and badlands (fig. 3). The eastern part of the basin is located in the Northwestern Glaciated Plains ecoregion and is characterized by flat, rolling terrain with numerous small lakes, wetlands, and prairie potholes.

The Missouri River flows southeastward across North Dakota into South Dakota. The river's streamflow is regulated by a series of dams built on its main stem and tributaries (Macek-Rowland, 2000). Six major dams and reservoirs were built on the upper main stem of the Missouri River, in part, to control flooding and for water resource development (Macek-Rowland, 2000). These dams and reservoirs are regulated by the U.S. Army Corps of Engineers. Built in 1952, Garrison Dam and Lake Sakakawea, the reservoir behind Garrison Dam, are located south of Garrison, North Dakota in the central part of the state (fig. 2). Depending on the elevation of impounded water behind Garrison Dam, the headwaters of Lake Sakakawea can reach nearly to Williston, N. Dak. Another reservoir on the Missouri River, Lake Oahe, is impounded by Oahe Dam, located about 112 miles south of the North Dakota-South Dakota State line, in central South Dakota. The headwaters for this reservoir can extend upstream to a few miles south of Bismarck. The river between Garrison Dam and the headwaters of Lake Oahe in South Dakota is the only free-flowing stretch (about 80 miles) of the Missouri River located in North Dakota. In addition to the dams on the Missouri River, there are many smaller impoundments throughout the Missouri River subbasins in North Dakota (North Dakota Water Education Foundation, 2009).

Management of the flow, including flood control, from the dams on the upper Missouri River main stem is dependent 
Table 3. Snowfall totals for selected cities or towns in the Missouri River and Red River of the North subbasins in North Dakota, western Minnesota, and northeastern South Dakota, for 1997 and 2008-09.

[Data from U.S. Department of Commerce, National Oceanic and Atmospheric Administration, National Environmental Satellite, Data and Information Service, Climatological data, for North Dakota, 2009b and 1997a; Snowfall totals are for the annual period beginning in July 1 of one year and ending in June 30 of the succeeding year; na, not available]

\begin{tabular}{|c|c|c|c|c|}
\hline Name of city or town & Period of record & $\begin{array}{c}\text { Average annual } \\
\text { snowfall totals, } \\
\text { in inches }\end{array}$ & $\begin{array}{c}1997 \\
\text { snowfall totals, } \\
\text { in inches }\end{array}$ & $\begin{array}{c}2009 \\
\text { snowfall totals, } \\
\text { in inches }\end{array}$ \\
\hline Bismarck, N. Dak. & $1875-2009$ & 44.3 & 101.8 & 100.5 \\
\hline Beulah, N. Dak. & na & a30 & 56.0 & 81.6 \\
\hline Dickinson, N. Dak. & 1903-2009 & a30-34 & 54.1 & 66.5 \\
\hline Grand Forks, N. Dak./East Grand Forks, Minn. & $1941-2009$ & a38 & 97.9 & 53.4 \\
\hline Jamestown, N. Dak. & $1891-2009$ & a34 & 52.8 & 87.8 \\
\hline Linton, N. Dak. & na & a30-34 & 81.1 & 101.5 \\
\hline Wahpeton, N. Dak./Breckenridge, Minn. & na & a34 & 64.0 & 73.6 \\
\hline
\end{tabular}

${ }^{a}$ Based on approximate values derived from average mean annual snowfall map for period 1930-31 through 1959-60 for Climate of North Dakota accessed January 2011 at http://www.npwrc.usgs.gov/resource/habitat/climate/figure42.htm.

not only on the timing of runoff from the headwaters and subbasins but also on the infiltration rate and distribution of runoff throughout the subbasins, climatic conditions, channel conditions, and water use. By continually monitoring these conditions, water resource managers can help control and limit most flooding events; however, even with careful monitoring and controls in place, there are times when unforeseen natural conditions can occur rapidly causing severe flooding, which occurred on the reach below Garrison Dam in March 2009.

Within the part of the Missouri River Basin in North Dakota there are several smaller rivers and streams with their own basins that are tributaries to the Missouri River. These smaller basins, like the Little Missouri and James Rivers, are considered subbasins of the Missouri River Basin. The Little Missouri and James Rivers are discussed as subbasins in this report. Some other rivers and streams within the Missouri River Basin in North Dakota that sustained recorded flooding in the spring of 2009 also are discussed in the Missouri River subbasin section of this report.

\section{Missouri River Subbasin}

In North Dakota, 12 record peak stages and 8 record peak discharges were recorded at several locations in the Missouri River Basin (table 4). Many locations experienced not just one, but two flood crests in about an 8-week period from March 20 through May 15, 2009. The two flood crests at several streamgages occurred because of additional spring rainfall on top of record winter snowfall and warm temperatures in late March. Ice jams, periodically making their way through the river system, caused backwater conditions resulting in higher river stages.

On March 24, 2009, the peak stage of the Missouri River at Bismarck, N. Dak., (site 19, fig. 2 , table 4), was 16.11 feet $(\mathrm{ft})$. The 2009 peak discharge was approximately $30,000 \mathrm{ft}^{3} / \mathrm{s}$ with a recurrence interval of less than 5 years. South of Bismarck, at the Missouri River near Schmidt, N. Dak., (site 30, fig. 2, and table 4) the peak stage was $24.24 \mathrm{ft}$ on March 25, 2009, which surpassed the previous peak of record of $23.56 \mathrm{ft}$ that occurred on December 9, 1976. Although the stage reached record levels at these streamgages, the discharge at these locations did not. The record high stages at both locations were caused by ice jams on the Missouri River north and south of the cities of Bismarck and Mandan in central North Dakota. The two ice jams on March 21-22, 2009, were the result of ice-laden flows from the Knife River located upstream from Bismarck and Mandan, and the ice-laden flow from Heart River entering the Missouri River at Mandan across from Bismarck (fig. 2). In an attempt to control the backup of flow from ice jams, the U.S. Army Corps of Engineers stopped releases from Garrison Dam to zero. This was the first time that releases had been shut off for an extended period of time (U.S. Army Corps of Engineer, Northwestern Division, news release no. 09-009, accessed January 2010 at http://www.nwd.usace.army.mil/pa/news/ shownews.asp?rn=09-009). Backwater from the ice jam south of Bismarck and Mandan forced the evacuation of nearly 1,700 residents from southwest Bismarck (Environment News 


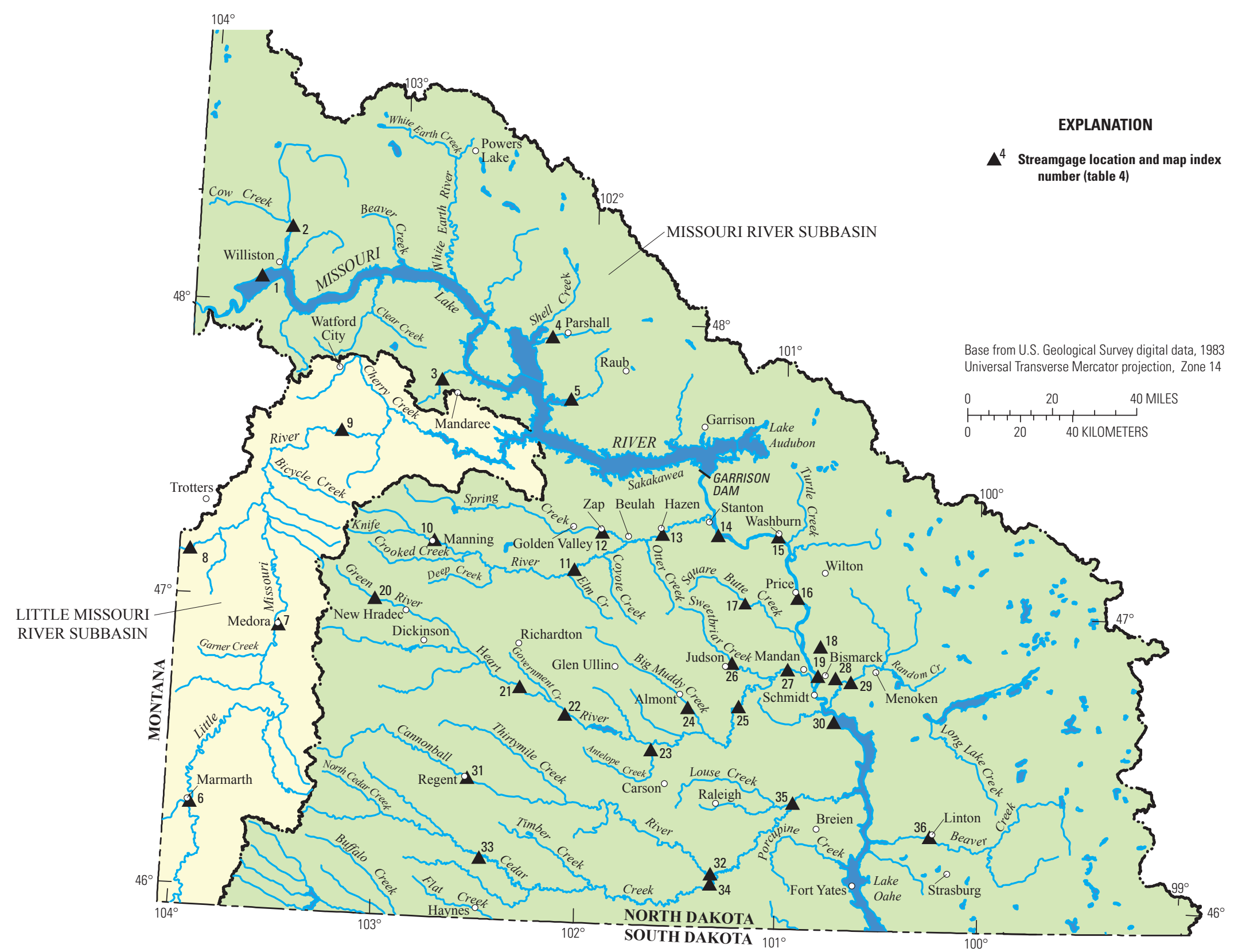

Figure 2. Locations of selected streamgages, rivers, streams, lakes, and cities in the Missouri River subbasin in North Dakota. 


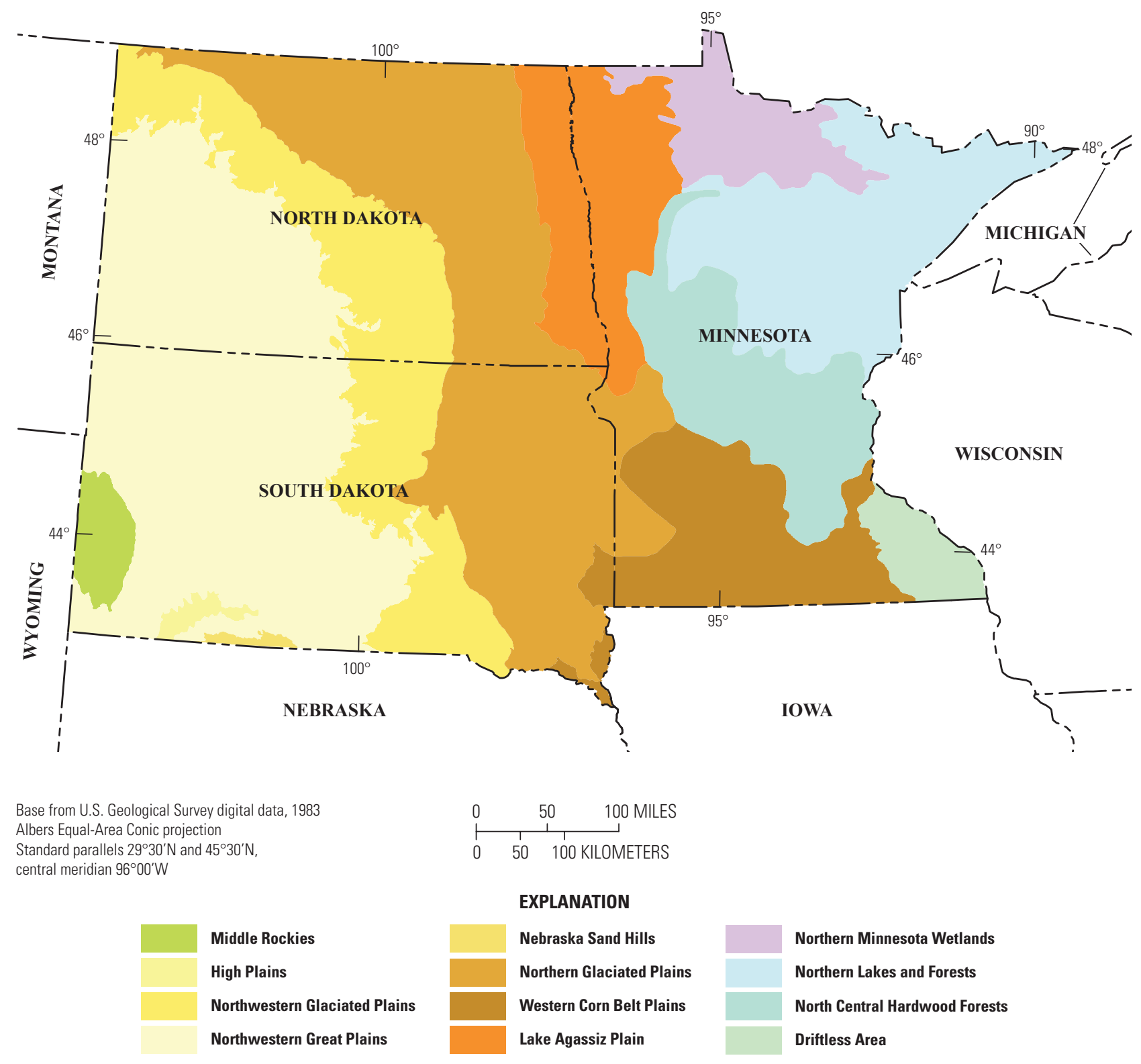

Figure 3. Ecoregions of North Dakota, Minnesota, and South Dakota.

Service, 2009, news release accessed January 2011 at $h t t p: / /$ www.ens-newswire.com/ens/mar2009/2009-03-26-091.html).

\section{Little Missouri River Subbasin}

The Little Missouri River subbasin covers an area of about $8,400 \mathrm{mi}^{2}$, of which $4,740 \mathrm{mi}^{2}$ are located in North Dakota. In North Dakota, the subbasin is located in the Northwestern Great Plains ecoregion (fig. 3) and is characterized by highly erodible badland topography with buttes, pinnacles, and sharp ridges. The Little Missouri River is a tributary of the Missouri River. In North Dakota, the Little Missouri River flows from the southwest to the north and meanders through grasslands and badland topography. The river turns eastward to enter the Missouri River at Lake Sakakawea where it forms an arm of the reservoir 30 miles long.

Although flooding did occur along the Little Missouri River in the spring of 2009, it was because of ice jams rather than large volumes of flow. As temperatures warmed in the southwestern part of North Dakota, snow and ice melted and flow began moving northward in the channel. Free-flowing ice and water moving downstream met a still frozen channel causing flow to spill over the banks and inundate campgrounds, pasture lands, and outbuildings located on nearby ranches. On April 17, 2009, the peak stage of the Little Missouri River at Marmarth, N. Dak., (site 6, fig. 2; table 4), was $16.85 \mathrm{ft}$. The 2009 peak discharge was $21,100 \mathrm{ft}^{3} / \mathrm{s}$, which was $23,900 \mathrm{ft}^{3} / \mathrm{s}$ less than the 1947 peak discharge of $45,000 \mathrm{ft}^{3} / \mathrm{s}$. The recurrence interval range for the 2009 peak discharge was 
Table 4. Historical and 2009 peak of record stages and discharges for the Missouri River subbasin in North Dakota.

[Data and footnotes in this table as well as additional station information can be found by searching on the station (site) number on the table in the U.S. Geological Survey's Water-resources data for the United States, Water Year 2009 accessed on January 2011 at $h t t p: / / w d r$ water.usgs.gov/wy2009/search.jsp. $\mathrm{mi}^{2}$, square miles; ft, feet; fts/s, cubic feet per second; red print, peak of record; na, not available; <, less than; reg. regulated]

\begin{tabular}{|c|c|c|c|c|c|c|c|c|c|c|c|c|}
\hline \multirow[b]{2}{*}{$\begin{array}{c}\text { Site } \\
\text { (fig. 2) }\end{array}$} & \multirow[b]{2}{*}{ Station name and number } & \multirow{2}{*}{$\begin{array}{c}\text { Drainage } \\
\text { area } \\
\left(\mathrm{mi}^{2}\right)\end{array}$} & \multicolumn{5}{|c|}{ Maximum peaks previously known from period of record } & \multicolumn{5}{|c|}{ Maximum peaks from March to September 2009} \\
\hline & & & $\begin{array}{c}\text { Period of } \\
\text { known } \\
\text { peaks }\end{array}$ & $\begin{array}{c}\text { Date of } \\
\text { peak stage }\end{array}$ & $\begin{array}{c}\text { Stage } \\
\text { (ft) }\end{array}$ & $\begin{array}{c}\text { Date of } \\
\text { peak } \\
\text { discharge }\end{array}$ & $\begin{array}{l}\text { Discharge } \\
\left(\mathrm{ft}^{3} / \mathbf{s}\right)\end{array}$ & $\begin{array}{c}\text { Date of } \\
\text { peak stage }\end{array}$ & $\begin{array}{l}\text { Stage } \\
\text { (ft) }\end{array}$ & $\begin{array}{c}\text { Date of } \\
\text { peak } \\
\text { discharge }\end{array}$ & $\begin{array}{l}\text { Discharge } \\
\left(\mathrm{ft}^{3} / \mathrm{s}\right)\end{array}$ & $\begin{array}{c}\text { Recurrence } \\
\text { interval } \\
\text { (years) }\end{array}$ \\
\hline 1 & $\begin{array}{l}\text { Missouri River near Williston, N. Dak. } \\
(06330000)\end{array}$ & 164,500 & $1966-2008$ & $03 / 08 / 1994$ & 26.60 & na & na & $06 / 27 / 2009$ & a21.24 & na & na & na \\
\hline 2 & $\begin{array}{l}\text { Little Muddy River below Cow Creek } \\
\text { near Williston, N. Dak. (06331000) }\end{array}$ & 875 & $1954-2008$ & $03 / 27 / 1960$ & 13.57 & 04/18/1979 & b9,180 & 04/09/2009 & ${ }^{\mathrm{c}} 11.24$ & $04 / 12 / 2009$ & d 2,700 & $<5$ \\
\hline 3 & $\begin{array}{l}\text { Bear Den Creek near Mandaree, N. Dak. } \\
\quad(06332515)\end{array}$ & 74 & $1966-2008$ & 04/06/1969 & 10.03 & 03/13/1972 & 2,840 & 03/23/2009 & ${ }^{\mathrm{c}} 7.72$ & $07 / 09 / 2009$ & ${ }^{\mathrm{e}} 114$ & $1.25-1.50$ \\
\hline 4 & $\begin{array}{l}\text { East Fork Shell Creek near Parshall, } \\
\text { N. Dak. (06332523) }\end{array}$ & 360 & 1991-2008 & 03/27/1997 & 6.46 & 03/27/1999 & 1,170 & 04/09/2009 & ${ }^{\circ} 6.46$ & $04 / 13 / 2009$ & ${ }^{\mathrm{f}} 760$ & $5-10$ \\
\hline 5 & $\begin{array}{l}\text { Deepwater Creek at mouth near Raub, } \\
\text { N. Dak (06332770) }\end{array}$ & 220 & 1991-2008 & 03/27/1997 & $\mathrm{c}, \mathrm{g} 13.26$ & 03/27/1997 & ${ }^{\mathrm{h}} 1,300$ & 03/23/2009 & ${ }^{\mathrm{c}} 13.24$ & $04 / 09 / 2009$ & $\mathrm{c}, \mathrm{h,i}, 1,200$ & $10-25$ \\
\hline 6 & $\begin{array}{l}\text { Little Missouri River at Marmarth, } \\
\text { N. Dak. (06335500) }\end{array}$ & 4,640 & 1938-2008 & $03 / 31 / 1952$ & c23.40 & 03/23/1947 & j45,000 & $04 / 17 / 2009$ & 16.85 & $04 / 17 / 2009$ & 21,100 & $10-25$ \\
\hline 7 & $\begin{array}{l}\text { Little Missouri River at Medora, } \\
\text { N. Dak. }(06336000)\end{array}$ & 6,190 & $\begin{array}{l}1903-1908 \\
1921-1924 \\
1928-1934 \\
1945-1975 \\
2001-2008\end{array}$ & 03/23/1947 & 20.50 & 03/23/1947 & 65,000 & 04/19/2009 & 16.43 & $04 / 19 / 2009$ & 20,800 & $5-10$ \\
\hline 8 & $\begin{array}{l}\text { Beaver Creek near Trotters, N. Dak. } \\
\quad(06336600)\end{array}$ & 616 & 1977-2008 & 03/22/1978 & '19.27 & 03/29/1978 & ${ }^{k} 2,720$ & 03/18/2009 & 10.42 & 03/18/2009 & 760 & $<5$ \\
\hline 9 & $\begin{array}{l}\text { Little Missouri River near Watford City } \\
\quad(06337000)\end{array}$ & 8,310 & 1934-2008 & $03 / 25 / 1947$ & $\mathrm{~g}_{24.00}$ & 03/25/1947 & $110 \mathrm{z}, 000$ & 04/21/2009 & 13.68 & $04 / 21 / 2009$ & 20,800 & $<5$ \\
\hline 10 & $\begin{array}{l}\text { Knife River near Manning, N. Dak. } \\
\quad(06339100)\end{array}$ & 205 & $1967-2008$ & $03 / 18 / 2003$ & ${ }^{\mathrm{c}} 17.63$ & 03/18/2003 & ${ }^{\mathrm{h}} 3,800$ & 03/22/2009 & 14.89 & $03 / 22 / 2009$ & 1,590 & $<5$ \\
\hline 11 & $\begin{array}{l}\text { Knife River near Golden Valley, N. Dak. } \\
\quad(06339500)\end{array}$ & 1,230 & $\begin{array}{l}1903-1906 \\
1907-1915 \\
1916-1919 \\
1921-1924 \\
1943-2008\end{array}$ & 03/26/1943 & 26.70 & 05/09/1970 & 11,200 & 03/22/2009 & $\mathrm{g}_{2} 7.73$ & $03 / 22 / 2009$ & 15,000 & $50-100$ \\
\hline 12 & $\begin{array}{l}\text { Spring Creek at Zap, N. Dak. } \\
\quad(06340000)\end{array}$ & 549 & $\begin{array}{c}1924 \\
1945-2008\end{array}$ & 03/15/1972 & 20.70 & $04 / 07 / 1952$ & ${ }^{1} 6,130$ & 03/23/2009 & 21.29 & 03/23/2009 & ${ }^{1} 6,340$ & $10-25$ \\
\hline 13 & $\begin{array}{l}\text { Knife River at Hazen, N. Dak. } \\
\quad(06340500)\end{array}$ & 2,240 & $\begin{array}{c}1928 \\
1929-1933 \\
1937-2008\end{array}$ & $06 / 24 / 1966$ & 27.01 & 06/24/1966 & 35,300 & 03/24/2009 & c27.79 & 03/23/2009 & $\mathrm{m} 27,400$ & $50-100$ \\
\hline 14 & $\begin{array}{l}\text { Missouri River near Stanton, N. Dak. } \\
\quad(06340700)\end{array}$ & 182,000 & $\begin{array}{c}1959 \\
1960-2008\end{array}$ & $02 / 22 / 1965$ & 24.56 & na & na & $12 / 16 / 2008$ & 12.85 & na & na & na \\
\hline 15 & $\begin{array}{l}\text { Missouri River at Washburn, N. Dak. } \\
(06341000)\end{array}$ & 184,000 & $1960-2008$ & 01/11/1964 & 22.76 & na & na & $02 / 28 / 2009$ & 14.48 & na & na & na \\
\hline
\end{tabular}


[Data and footnotes in this table as well as additional station information can be found by searching on the station (site) number on the table in the U.S. Geological Survey's Water-resources data for the United States, Water Year 2009 accessed on January 2011 at $h t t p: / / w d r$ water.usgs.gov/wy2009/search.jsp. $\mathrm{mi}^{2}$, square miles; ft, feet; fts, cubic feet per second; red print, peak of record; na, not available; <, less than; reg. regulated]

\begin{tabular}{|c|c|c|c|c|c|c|c|c|c|c|c|c|}
\hline \multirow[b]{2}{*}{$\begin{array}{l}\text { Site } \\
\text { (fig. 2) }\end{array}$} & \multirow[b]{2}{*}{ Station name and number } & \multirow[b]{2}{*}{$\begin{array}{c}\text { Drainage } \\
\text { area } \\
\left(\mathbf{m i}^{2}\right)\end{array}$} & \multicolumn{5}{|c|}{ Maximum peaks previously known from period of record } & \multicolumn{5}{|c|}{ Maximum peaks from March to September 2009} \\
\hline & & & $\begin{array}{c}\text { Period of } \\
\text { known } \\
\text { peaks }\end{array}$ & $\begin{array}{c}\text { Date of } \\
\text { peak stage }\end{array}$ & $\begin{array}{c}\text { Stage } \\
\text { (ft) }\end{array}$ & $\begin{array}{c}\text { Date of } \\
\text { peak } \\
\text { discharge }\end{array}$ & $\begin{array}{l}\text { Discharge } \\
\left(\mathrm{ft}^{3} / \mathrm{s}\right)\end{array}$ & $\begin{array}{c}\text { Date of } \\
\text { peak stage }\end{array}$ & $\begin{array}{c}\text { Stage } \\
\text { (ft) }\end{array}$ & $\begin{array}{c}\text { Date of } \\
\text { peak } \\
\text { discharge }\end{array}$ & $\begin{array}{l}\text { Discharge } \\
\left(\mathrm{ft}^{3} / \mathrm{s}\right)\end{array}$ & $\begin{array}{c}\text { Recurrence } \\
\text { interval } \\
\text { (years) }\end{array}$ \\
\hline 16 & $\begin{array}{l}\text { Missouri River at Price, N. Dak. } \\
(06342020)\end{array}$ & 185,000 & 1959-2008 & $01 / 22 / 1967$ & 30.12 & na & na & $03 / 25 / 2009$ & 22.59 & na & na & na \\
\hline 17 & $\begin{array}{l}\text { Square Butte Creek below Center, } \\
\text { N. Dak. }(06342260)\end{array}$ & 146 & $1965-2008$ & $06 / 24 / 1966$ & 14.35 & $06 / 24 / 1966$ & 9,700 & 03/23/2009 & ${ }^{\mathrm{c}} 9.68$ & $03 / 23 / 2009$ & n,o 1,800 & $5-10$ (reg.) \\
\hline 18 & $\begin{array}{l}\text { Burnt Creek near Bismarck, N. Dak. } \\
\quad(06342450)\end{array}$ & 108 & $1967-2008$ & 04/18/1979 & 16.93 & $04 / 18 / 1979$ & $\mathrm{p} 10,000$ & 04/13/2009 & 14.89 & $04 / 13 / 2009$ & 1,690 & $5-10$ \\
\hline 19 & $\begin{array}{l}\text { Missouri River at Bismarck, N. Dak. } \\
\quad(06342500)\end{array}$ & 186,400 & $1927-2008$ & $03 / 31 / 1881$ & 931.60 & $04 / 06 / 1952$ & 500,000 & 03/24/2009 & c,r 16.11 & $03 / 24 / 2009$ & $\mathrm{c}, \mathrm{h}, \mathrm{o} 30,000$ & $<5$ (reg.) \\
\hline 20 & $\begin{array}{l}\text { Green River near New Hradec, } \\
\text { N. Dak. }(06344600)\end{array}$ & 152 & 1964-2008 & 03/21/1997 & c19.58 & 05/09/1970 & 4,120 & 03/18/2009 & ${ }^{\mathrm{c}} 17.17$ & 03/18/2009 & ${ }^{\mathrm{h}} 1,350$ & $<5$ \\
\hline 21 & $\begin{array}{l}\text { Heart River near Richardton, N. Dak. } \\
\quad(06345500)\end{array}$ & 1,240 & $\begin{array}{l}1905-1921 \\
1943-2008\end{array}$ & 03/30/1912 & $\mathrm{c}, \mathrm{h} 28.50$ & $04 / 16 / 1950$ & 23,400 & $04 / 14 / 2009$ & 23.77 & $04 / 14 / 2009$ & ${ }^{\circ} 12,800$ & 10-25 (reg.) \\
\hline 22 & $\begin{array}{l}\text { Heart River above Lake Tschida near } \\
\text { Glen Ullin, N. Dak. (06345780) }\end{array}$ & 1,530 & 1988-2008 & 03/21/1997 & ${ }^{\prime} 26.74$ & 03/22/1997 & h,l 11,500 & 03/23/2009 & c25.79 & $04 / 13 / 2009$ & $\mathrm{~h}, \mathrm{o} 13,000$ & $10-25$ \\
\hline 23 & $\begin{array}{l}\text { Antelope Creek near Carson, N. Dak. } \\
\quad(06347000)\end{array}$ & 221 & $\begin{array}{l}1948-1975 \\
1999-2008\end{array}$ & 05/09/1970 & 19.10 & $04 / 16 / 1950$ & ${ }^{\mathrm{s}} 11,100$ & $04 / 13 / 2009$ & 18.08 & $04 / 13 / 2009$ & 6,820 & $10-25$ \\
\hline 24 & $\begin{array}{l}\text { Big Muddy Creek near Almont, N. Dak. } \\
\quad(06347500)\end{array}$ & 456 & $\begin{array}{l}1945-1970 \\
1971-1973 \\
1991-2008\end{array}$ & 07/23/1993 & c30.99 & $04 / 17 / 1950$ & 20,200 & 04/13/2009 & 30.15 & $04 / 13 / 2009$ & 9,200 & $25-50$ \\
\hline 25 & $\begin{array}{l}\text { Heart River at Stark Bridge near Judson, } \\
\text { N. Dak. }(06348300)\end{array}$ & 2,930 & $1986-2008$ & 03/23/1997 & $c 21.90$ & 03/23/1997 & h,1 18,000 & 03/23/2009 & 22.13 & $03 / 23 / 2009$ & ${ }^{\circ} 23,300$ & $10-25$ (reg.) \\
\hline 26 & $\begin{array}{l}\text { Sweetbriar Creek near Judson, N. Dak. } \\
\quad(06348500)\end{array}$ & 157 & $\begin{array}{l}1951-1979 \\
2002-2008\end{array}$ & $04 / 17 / 1950$ & ${ }^{\mathrm{g}} 12.50$ & $04 / 17 / 50$ & "5,910 & $04 / 13 / 2009$ & 12.77 & $04 / 13 / 2009$ & ${ }^{\circ} 6,150$ & $10-25$ (reg.) \\
\hline 27 & $\begin{array}{l}\text { Heart River near Mandan, N. Dak. } \\
\quad(06349000)\end{array}$ & 3,310 & $\begin{array}{c}1924 \\
1928-33 \\
1937-2008\end{array}$ & $04 / 04 / 1952$ & ${ }^{\prime} 25.75$ & $04 / 19 / 1950$ & $\mathrm{~h}, 130,500$ & 03/24/2009 & 24.07 & $03 / 24 / 2009$ & ${ }^{\circ} 29,200$ & 10-25 (reg.) \\
\hline 28 & $\begin{array}{l}\text { Apple Creek near Menoken, N. Dak. } \\
\quad(06349500)\end{array}$ & 1,680 & $\begin{array}{c}1905 \\
1945-2008\end{array}$ & 04/19/1979 & 17.46 & $04 / 18 / 1950$ & ${ }^{v} 6,750$ & $04 / 13 / 2009$ & 17.22 & $04 / 13 / 2009$ & 5,940 & $25-50$ \\
\hline 29 & $\begin{array}{l}\text { Hay Creek at Main Avenue in Bismarck, } \\
\text { N. Dak. (06349600) }\end{array}$ & 31.2 & $2002-2008$ & $06 / 07 / 2007$ & 7.35 & $06 / 07 / 2007$ & 456 & $06 / 15 / 2009$ & 7.99 & $06 / 15 / 2009$ & 749 & na \\
\hline 30 & $\begin{array}{l}\text { Missouri River near Schmidt, N. Dak. } \\
\quad(06349700)\end{array}$ & 191,700 & $1966-2008$ & $12 / 09 / 1976$ & 23.56 & na & na & $03 / 25 / 2009$ & 24.24 & na & na & na \\
\hline 31 & $\begin{array}{l}\text { Cannonball River at Regent, N. Dak. } \\
\text { (06350000) }\end{array}$ & 580 & $1950-2008$ & 03/21/1997 & ${ }^{c} 21.01$ & $03 / 27 / 1978$ & w10,000 & $03 / 22 / 2009$ & ${ }^{\mathrm{c}} 18.66$ & $04 / 15 / 2009$ & $\times 7,510$ & $10-25$ \\
\hline 32 & $\begin{array}{l}\text { Cannonball River at Raleigh, N. Dak. } \\
\text { (06351200) }\end{array}$ & 1,640 & 2001-2008 & na & na & q03/20/1997 & 15,000 & 03/24/2009 & 16.50 & $03 / 24 / 2009$ & 18,500 & na \\
\hline 33 & $\begin{array}{l}\text { Cedar Creek near Haynes, N. Dak. } \\
(06352000)\end{array}$ & 553 & $1950-2008$ & 03/28/1978 & c22.05 & $04 / 07 / 1952$ & ${ }^{y} 7,870$ & 03/21/2009 & ${ }^{c} 21.57$ & $03 / 22 / 2009$ & $\mathrm{z} 7,720$ & $10-25$ \\
\hline
\end{tabular}


Table 4. Historical and 2009 peak of record stages and discharges for the Missouri River subbasin in North Dakota.—Continued

[Data and footnotes in this table as well as additional station information can be found by searching on the station (site) number on the table in the U.S. Geological Survey's Water-resources data for the United States, Water Year 2009 accessed on January 2011 at $h t t p: / / w d r$ water.usgs.gov/wy2009/search.jsp. $\mathrm{mi}^{2}$, square miles; ft, feet; fts/s, cubic feet per second; red print, peak of record; na, not available; <, less than; reg. regulated]

\begin{tabular}{|c|c|c|c|c|c|c|c|c|c|c|c|c|}
\hline \multirow[b]{2}{*}{$\begin{array}{l}\text { Site } \\
\text { (fig. 2) }\end{array}$} & \multirow[b]{2}{*}{ Station name and number } & \multirow[b]{2}{*}{$\begin{array}{c}\text { Drainage } \\
\text { area } \\
\left(\mathrm{mi}^{2}\right)\end{array}$} & \multicolumn{5}{|c|}{ Maximum peaks previously known from period of record } & \multicolumn{5}{|c|}{ Maximum peaks from March to September 2009} \\
\hline & & & $\begin{array}{c}\text { Period of } \\
\text { known } \\
\text { peaks }\end{array}$ & $\begin{array}{c}\text { Date of } \\
\text { peak stage }\end{array}$ & $\begin{array}{c}\text { Stage } \\
\text { (ft) }\end{array}$ & $\begin{array}{c}\text { Date of } \\
\text { peak } \\
\text { discharge }\end{array}$ & $\begin{array}{l}\text { Discharge } \\
\left(\mathrm{ft}^{3} / \mathbf{s}\right)\end{array}$ & $\begin{array}{c}\text { Date of } \\
\text { peak stage }\end{array}$ & $\begin{array}{c}\text { Stage } \\
\text { (ft) }\end{array}$ & $\begin{array}{c}\text { Date of } \\
\text { peak } \\
\text { discharge }\end{array}$ & $\begin{array}{c}\text { Discharge } \\
\left(\mathrm{ft}^{3} / \mathrm{s}\right)\end{array}$ & $\begin{array}{c}\text { Recurrence } \\
\text { interval } \\
\text { (years) }\end{array}$ \\
\hline 34 & $\begin{array}{l}\text { Cedar Creek near Raleigh, N. Dak. } \\
\quad(06353000)\end{array}$ & 1,750 & $\begin{array}{c}1939 \\
1962-2008\end{array}$ & $03 / 24 / 1997$ & ${ }^{\mathrm{c}} 17.05$ & $03 / 24 / 1997$ & 14,600 & $03 / 23 / 2009$ & ${ }^{c} 20.59$ & $03 / 23 / 2009$ & ${ }^{\circ} 16,000$ & $25-50$ \\
\hline 35 & $\begin{array}{l}\text { Cannonball River at Breien, N. Dak. } \\
(06354000)\end{array}$ & 4,100 & 1934-2008 & $04 / 19 / 1950$ & $\mathrm{~g}_{22.30}$ & $04 / 19 / 1950$ & aаa4,800 & $03 / 24 / 2009$ & $\mathrm{c}, \mathrm{g} 21.84$ & $03 / 24 / 2009$ & ${ }^{\circ} 30,000$ & $10-25$ \\
\hline 36 & $\begin{array}{l}\text { Beaver Creek near Linton, N. Dak. } \\
\quad(06354580)\end{array}$ & 765 & 1989-2008 & 03/31/1997 & 15.34 & 03/31/1997 & 6,780 & $03 / 24 / 2009$ & ${ }^{\mathrm{g}} 18.96$ & $03 / 24 / 2009$ & ${ }^{\mathrm{bb}} 14,000$ & $25-50$ \\
\hline
\end{tabular}

aMaximum daily value.

${ }^{\mathrm{b}}$ Gage height, 12.77 feet.

'Backwater from ice, debris, aquatic vegetation, or other water source.

${ }^{\mathrm{d}}$ Gage height, 10.60 feet.

${ }^{\mathrm{e}} \mathrm{Gage}$ height, 5.67 feet.

fGage height, 6.35 feet.

${ }^{g}$ From high-water mark.

${ }^{\mathrm{h}}$ Estimated based on best available data.

iGage height, 12.71 feet.

${ }^{\mathrm{j}}$ Gage height, 21.70 feet.

${ }^{\mathrm{k}}$ Gage height, 18.61 feet.

'Discharge affected to unknown degree by regulation or diversion.

${ }^{\mathrm{m}}$ Gage height, 27.13 feet.

${ }^{n}$ Gage height, 9.35 feet.

${ }^{\circ}$ Discharge affected by regulation or diversion.

pFrom rating curve extended above 2,220 cubic feet per second on basis of indirect measurement of peak flow at U.S. Highway 83.

${ }^{9}$ Extreme outside period of record.

${ }^{\mathrm{r}}$ Peak since completion of Garrison Dam.

${ }^{\mathrm{s}}$ From rating curve extended above 1,000 cubic feet per second on basis of slope-area measurement. 'From rating curve extended above 2,300 cubic feet per second on basis of slope-area measurement.

"From rating curve extended above 2,000 cubic feet per second on basis of contracted-opening measurement.

${ }^{v}$ Gage height, 17.07 feet.

${ }^{\text {w} G a g e ~ h e i g h t, ~} 20.55$ feet.

${ }^{\mathrm{x}}$ Gage height, 18.38 feet.

${ }^{y}$ Gage height, 21.25 feet.

${ }^{2}$ Gage height, 21.37 feet.

aaFrom rating curve extended above 16,000 cubic feet per second on basis of indirect discharge.

${ }^{b b}$ From rating curve extended above 8,000 cubic feet per second on basis of indirect measurement. 
10-25 years. At the Little Missouri River at Medora, N. Dak., (site 7, fig. 2; table 4), the peak stage was $16.43 \mathrm{ft}$ on April 19, 2009. The 2009 peak discharge was $20,800 \mathrm{ft}^{3} / \mathrm{s}$, which was $44,200 \mathrm{ft}^{3} / \mathrm{s}$ less than the 1947 peak discharge of $65,000 \mathrm{ft}^{3} / \mathrm{s}$. The recurrence interval range for the 2009 peak discharge was 5-10 years. On April 21, 2009, the peak stage of the Little Missouri River at Watford City, N. Dak., (site 9, fig. 2; table 4), was $13.68 \mathrm{ft}$. The 2009 peak discharge was 20,800 $\mathrm{ft}^{3} / \mathrm{s}$, which was $89,200 \mathrm{ft}^{3} / \mathrm{s}$ less than the 1947 peak discharge of $110,000 \mathrm{ft}^{3} / \mathrm{s}$. The recurrence interval range for the 2009 peak discharge was less than 5 years.

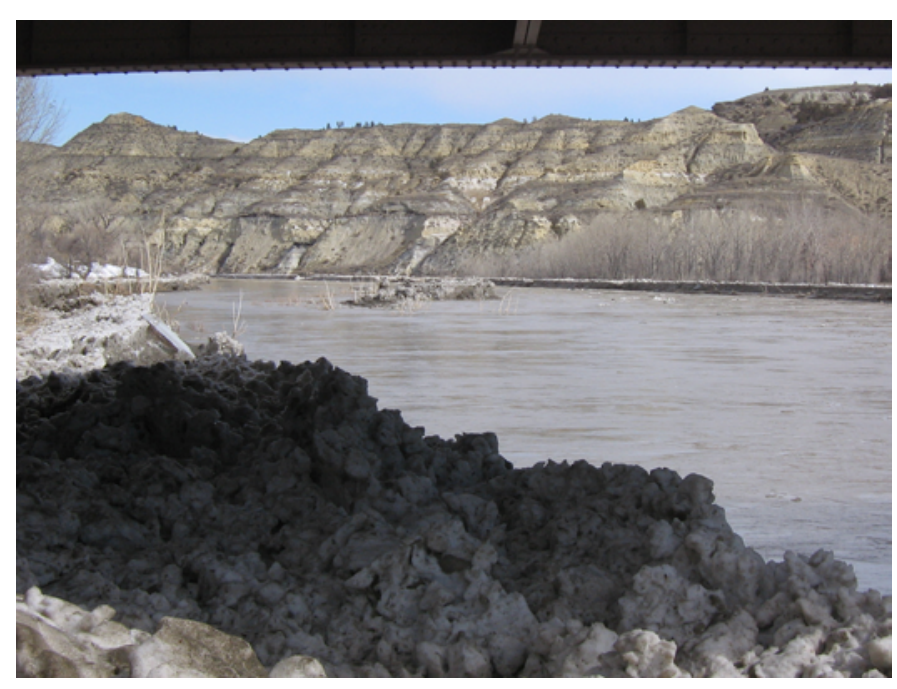

Ice chunks underneath a bridge on the Little Missouri River near Medora, North Dakota, March 16, 2009. Photograph by U.S. Geological Survey personnel.

\section{Subbasins of Other Tributaries to the Missouri River}

Several tributaries flow into the Missouri River between Garrison Dam and the headwaters of Lake Oahe (fig. 2). The largest tributaries located west of the Missouri River are the Knife, Heart, and Cannonball Rivers and Cedar Creek. These tributaries are located in the Northwestern Great Plains ecoregion (fig. 3) and occupy well-defined valleys in an area characterized by few lakes, numerous hills, and steep-sided buttes.

The largest eastern tributary to the Missouri River in North Dakota is the James River, which flows to the south and joins the Missouri River in South Dakota (and will be discussed in the next section). Two other larger tributaries located east of the Missouri River are Apple and Beaver Creeks

(fig. 1). Except for the James River, the eastern tributaries generally have smaller basins than those tributaries located west of the Missouri River. The tributaries that flow from the east are located in the Northwestern Glaciated Plains ecoregion and are characterized by gently rolling hills and numerous small lakes and wetlands (fig. 3). These small lakes and wetlands make up part of the Northwestern Glaciated Plains ecoregion in North Dakota and may have considerable noncontributing areas. [Noncontributing areas are where water may collect for some time before reaching a point of elevation where it spills over to next lower-in-elevation water body or subbasin or watershed. Under normal hydrologic conditions, these areas do not normally contribute much surface flow to a tributary or river; however, during times of flooding and depending on the antecedent conditions in and around the noncontributing areas, these areas may contribute considerable surface flow to a flooding situation or conversely retain or retard considerable amounts of flow from moving through a system.]

On March 22, 2009, the peak stage of the Knife River near Golden Valley, N. Dak., (site 11, fig. 2, table 4), was $27.73 \mathrm{ft}$ with a peak discharge was $15,000 \mathrm{ft}^{3} / \mathrm{s}$. The 2009 peak discharge was $8,600 \mathrm{ft}^{3} / \mathrm{s}$ more than the 1997 peak of 6,400 $\mathrm{ft}^{3} / \mathrm{s}$. The recurrence interval range for the 2009 peak discharge was 50-100 years. The previous peak of record discharge of 11,200 ft $\mathrm{ft}^{3} / \mathrm{s}$ occurred on May 9, 1970. On March 23, 2009, the peak stage of the Knife River at Hazen, N. Dak., (site 13, fig. 2, table 4), was $27.79 \mathrm{ft}$ and was a new record. The peak discharge was $27,400 \mathrm{ft}^{3} / \mathrm{s}$, which was $6,900 \mathrm{ft}^{3} / \mathrm{s}$ more than the 1997 peak discharge. The recurrence interval ranges for the 2009 peak discharge was 50-100 years. The peak of record discharge of $35,300 \mathrm{ft}^{3} / \mathrm{s}$ occurred on June 24, 1966. Flooding along this reach of the Knife River affected the nearby cities of Beulah, N. Dak., and Hazen, N. Dak. Nearly 40 homes in Beulah were evacuated as well as several homes next to the river. The extent of flooding was such that many people were evacuated by boat (North Dakota Water Education Foundation, 2009).

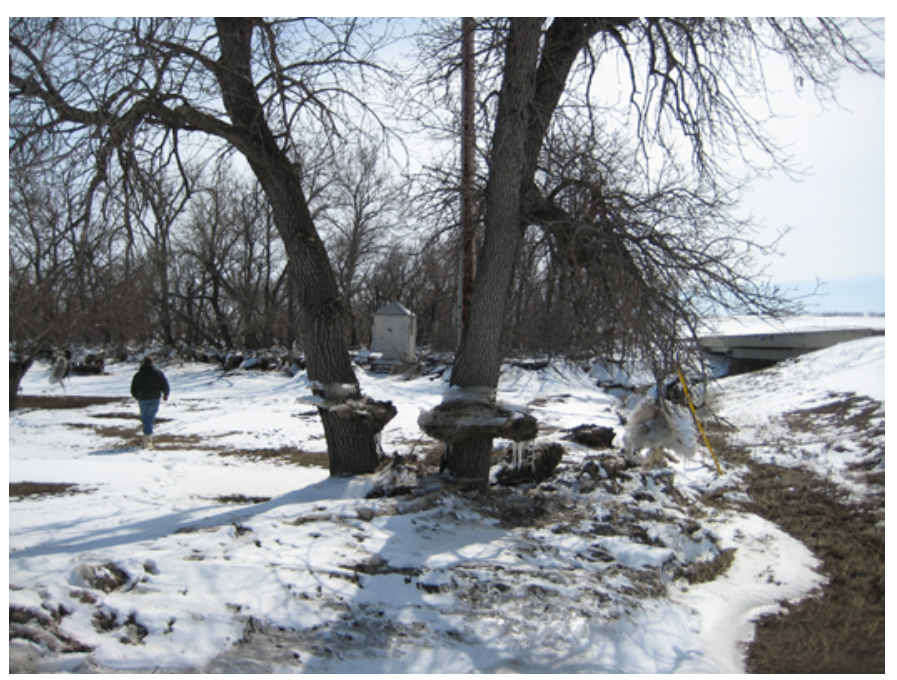

Ice from floodwaters still attached to tree trunks next to the Knife River at Hazen, North Dakota, April 1, 2009 (fig. 2, site 13). Photograph by U.S. Geological Survey personnel.

At Spring Creek at Zap, N. Dak., (site 12, fig. 2, table 4), the peak stage was $21.29 \mathrm{ft}$ on March 23, 2009. The peak discharge was $6,340 \mathrm{ft}^{3} / \mathrm{s}$, which was $2,840 \mathrm{ft}^{3} / \mathrm{s}$ greater than the 1997 peak discharge. The recurrence interval range for the 
2009 peak discharge was $10-25$ years. The 2009 peak discharge was a new peak of record for this streamgage.

On March 23, 2009, the peak stage of the Heart River at Stark Bridge near Judson, N. Dak., (site 25, fig. 2, table 4), was $22.13 \mathrm{ft}$. The peak discharge was $23,300 \mathrm{ft}^{3} / \mathrm{s}$, which was $5,300 \mathrm{ft}^{3} / \mathrm{s}$ greater than the 1997 peak discharge. The recurrence interval range for the 2009 peak discharge was 10-25 years. The 2009 peak stage and peak discharge were new peaks of record for this streamgage. At the Heart River near Mandan, N. Dak., (site 27, fig. 2, table 4), the peak stage was $24.07 \mathrm{ft}$ on March 24, 2009 and the 2009 peak discharge was $29,200 \mathrm{ft}^{3} / \mathrm{s}$, which was $7,200 \mathrm{ft}^{3} / \mathrm{s}$ greater than the 1997 peak discharge. The recurrence interval range for the 2009 peak discharge was 10-25 years. The 2009 peak discharge was $1,300 \mathrm{ft}^{3} / \mathrm{s}$ less than the peak of record of $30,500 \mathrm{ft}^{3} / \mathrm{s}$ that occurred on April 19, 1950. The large flow ice and water from this river contributed to an ice jam that occurred on the Missouri River downstream from the cities of Bismarck and Mandan.

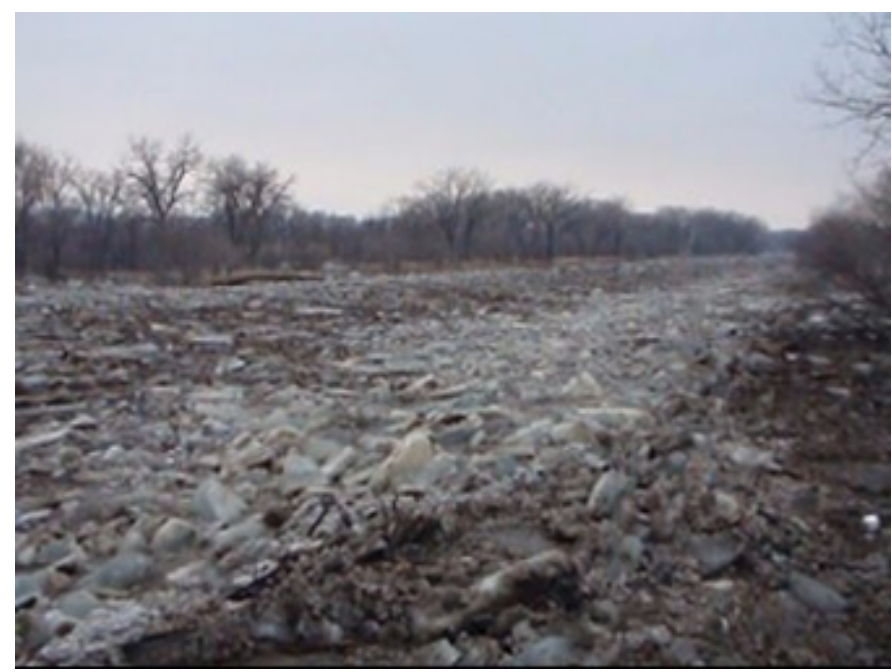

Ice jam on the Heart River near Mandan, North Dakota, March 22, 2009 (fig. 2, site 27). Photograph by Dave Aeschliman, U.S. Geological Survey.

On March 24, 2009, the peak stage for the Cannonball River near Raleigh, N. Dak., (site 32, fig. 2, table 4 ), was $16.50 \mathrm{ft}$. The peak discharge was $18,500 \mathrm{ft}^{3} / \mathrm{s}$, which was $3,500 \mathrm{ft}^{3} / \mathrm{s}$ greater than the 1997 peak discharge. The recurrence interval range for the 2009 peak discharge was not available. The 2009 peak stage and peak discharge were new peaks of record for this streamgage.

At Cedar Creek near Raleigh, N. Dak., (site 34, fig. 2, table 4), the peak stage was $20.59 \mathrm{ft}$ on March 23, 2009. The peak discharge was $16,000 \mathrm{ft}^{3} / \mathrm{s}$, which was $1,400 \mathrm{ft}^{3} / \mathrm{s}$ more than the 1997 peak discharge. The recurrence interval range for the 2009 peak discharge was 25-50 years. The 2009 peak stage and peak discharge were new peaks of record for this streamgage.
On March 24, 2009, the peak stage for Beaver Creek near Linton, N. Dak., (site 36, fig. 2, table 4), was $18.96 \mathrm{ft}$ or $3.62 \mathrm{ft}$ higher than the previous 1997 peak of record. The 2009 peak discharge was $14,000 \mathrm{ft}^{3} / \mathrm{s}$, which was $7,220 \mathrm{ft}^{3} / \mathrm{s}$ greater than the 1997 peak discharge of $6,780 \mathrm{ft}^{3} / \mathrm{s}$. The recurrence interval range for the 2009 peak discharge was 25-50 years. The 2009 peak stage and peak discharge were new peaks of record for this streamgage. Many families were evacuated from Linton, N. Dak., and surrounding areas as water covered parts of the town and nearby U.S. Highway 83 (North Dakota Water Education Foundation, 2009).

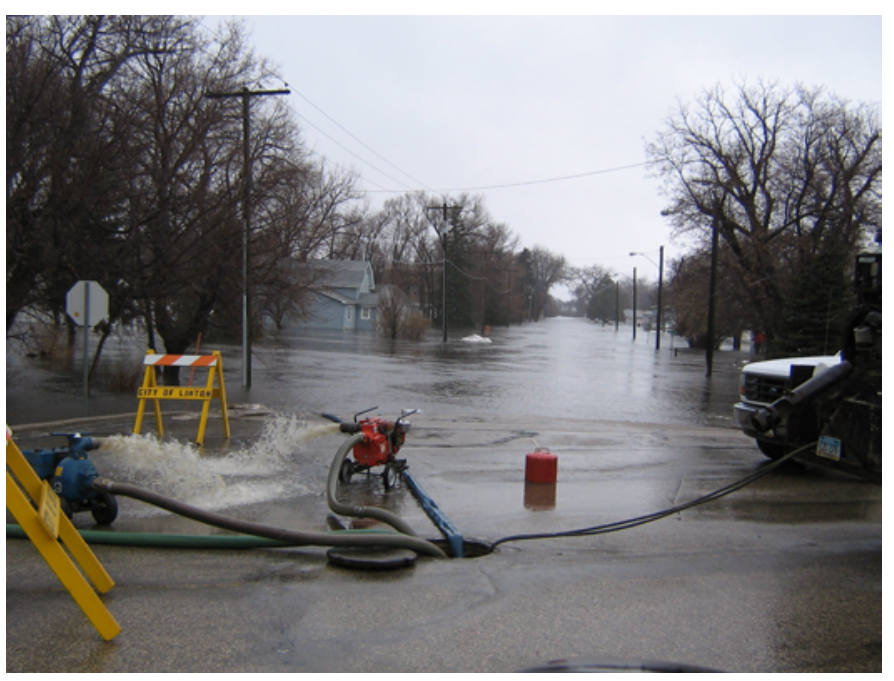

Pumps work to keep encroaching floodwaters from inundating the sewer system in Linton, North Dakota, March 24, 2009. Photograph by Larry Rutschke, U.S. Geological Survey.

\section{James River Subbasin}

The James River is one of the largest tributaries of the Missouri River in North Dakota. The headwaters of the James River are located in central North Dakota and it flows into the Missouri River in southeast South Dakota (fig. 1). In North Dakota, the basin is located in the Northwestern Glaciated Plains ecoregion (fig. 3) and is characterized by prairie potholes and wetlands. The drainage area for the basin is about 20,900 square miles of which 6,800 square miles are in North Dakota (fig. 4).

Discharge on the river is regulated by the Jamestown Dam (fig. 4) located in Jamestown, N. Dak. The dam and Jamestown reservoir were constructed for flood control and flow regulations. The reservoir has a maximum capacity of 389,100 acre-feet (elevation of 1,464.6 ft) and is managed by the U.S. Army Corps of Engineers (Ruddy and Hitt, 1990).

In the spring of 2009, record peak stages and discharges were recorded at several locations in the James River subbasin. Above-normal snowfall throughout the basin in North Dakota caused the worst flooding on record for many sites. In the city of Jamestown, 14,630 residents were put on alert as high flows made their way downstream toward the city 


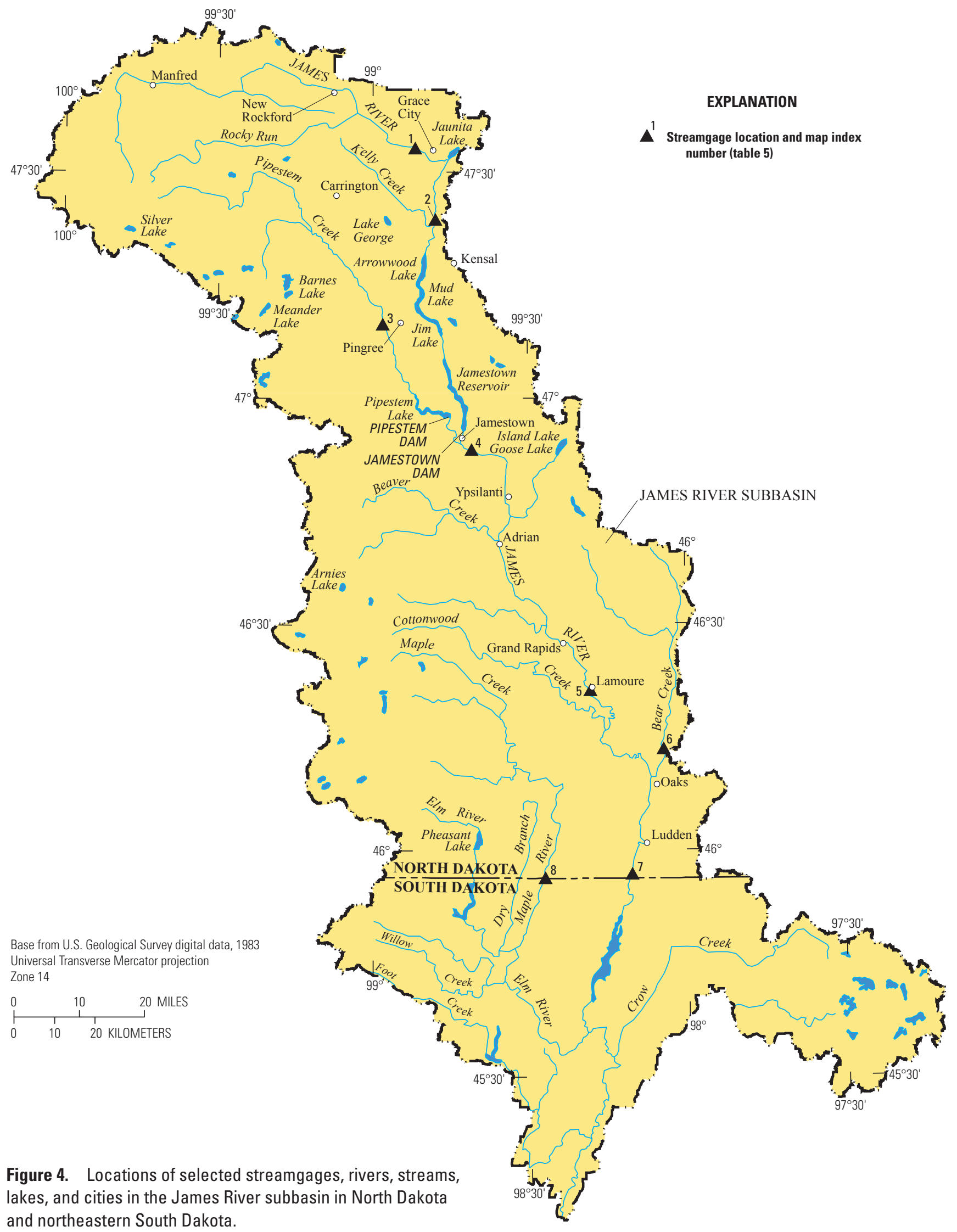


(U.S. Army Corps of Engineers, 2009c). Runoff from the snowmelt caused water to flow over the emergency spillway at Jamestown Dam (site 4, fig. 4, table 5) for the first time since it was built in 1953 (U.S. Army Corps of Engineers, Omaha District, written commun., 2010). On April 26, 2009, the Jamestown Reservoir reached a record elevation of 1,454.1 ft, which overtopped the spillway (elevation 1,454.0 ft) by $0.1 \mathrm{ft}$. The 2009 record was $8.2 \mathrm{ft}$ higher than the previous record of 1,445.9 feet recorded in May 1997. Approximately 600,000 acre-feet of water were stored then released from the Jamestown and Pipestem Dams (fig. 4) during the 2009 spring flood. These releases were regulated, and at times varied daily, to help mitigate the effects of flooding upstream and downstream from the dams. The James River remained above flood stage from April 14 to June 6, 2009 and resulted in the installation of 5.5 miles of levees and nearly 1.4 million sandbags to protect Jamestown (U.S. Army Corps of Engineers, 2009d).

Elsewhere in the James River subbasin, five peak of record stages and seven peak of record discharges were recorded at USGS streamgages on the James River and several of its tributaries in North Dakota (fig. 4, table 5). To monitor flooding on the James River, the USGS installed rapid deployment gages throughout the basin. Data from these gages when used in conjunction with data from established streamgages give a more comprehensive view of the flooding situation in the basin.

On April 17, 2009, the peak stage at the James River near Grace City, N. Dak., (site 1, fig. 4, table 5), was $17.74 \mathrm{ft}$. The peak discharge was $7,910 \mathrm{ft}^{3} / \mathrm{s}$, which was $3,910 \mathrm{ft}^{3} / \mathrm{s}$ greater than the previous peak discharge on April 3, 1997. The recurrence interval range for the 2009 peak discharge was between 25-50 years. The 2009 peak stage and peak discharge were new peaks of record for this streamgage. On April 15, 2009, the peak stage of the James River at LaMoure, N. Dak., (site 5, fig. 4, table 5), was $17.56 \mathrm{ft}$. The 2009 peak discharge was $12,200 \mathrm{ft}^{3} / \mathrm{s}$, which was $5,700 \mathrm{ft}^{3} / \mathrm{s}$ more than the 1997 peak discharge. The recurrence interval range for the 2009 peak discharge was 100-200 years. The 2009 peak stage and peak discharge were new peaks of record for this streamgage.

On April 14, 2009, the peak stage at the Pipestem Creek near Pingree, N. Dak., (site 3, fig. 4, and table 5) was $13.15 \mathrm{ft}$ on April 14, 2009 and the peak discharge was $9,200 \mathrm{ft}^{3} / \mathrm{s}$, which was $5,800 \mathrm{ft}^{3} / \mathrm{s}$ greater than the 1997 peak discharge. The recurrence interval range for the 2009 peak discharge was $50-100$ years. The 2009 peak stage and peak discharge were new peaks of record for this streamgage.

\section{Red River of the North Basin}

In the spring of 2009, several USGS streamgages on the Red River and several of its tributaries recorded peak of record stage or discharge or both as a result of a wet fall, record winter snowfall, and above-normal rainfall in the spring in the basin. The 2009 spring flood was the fourth $(1997,2001$, 2006) major flood to occur in this basin in the last 12 years

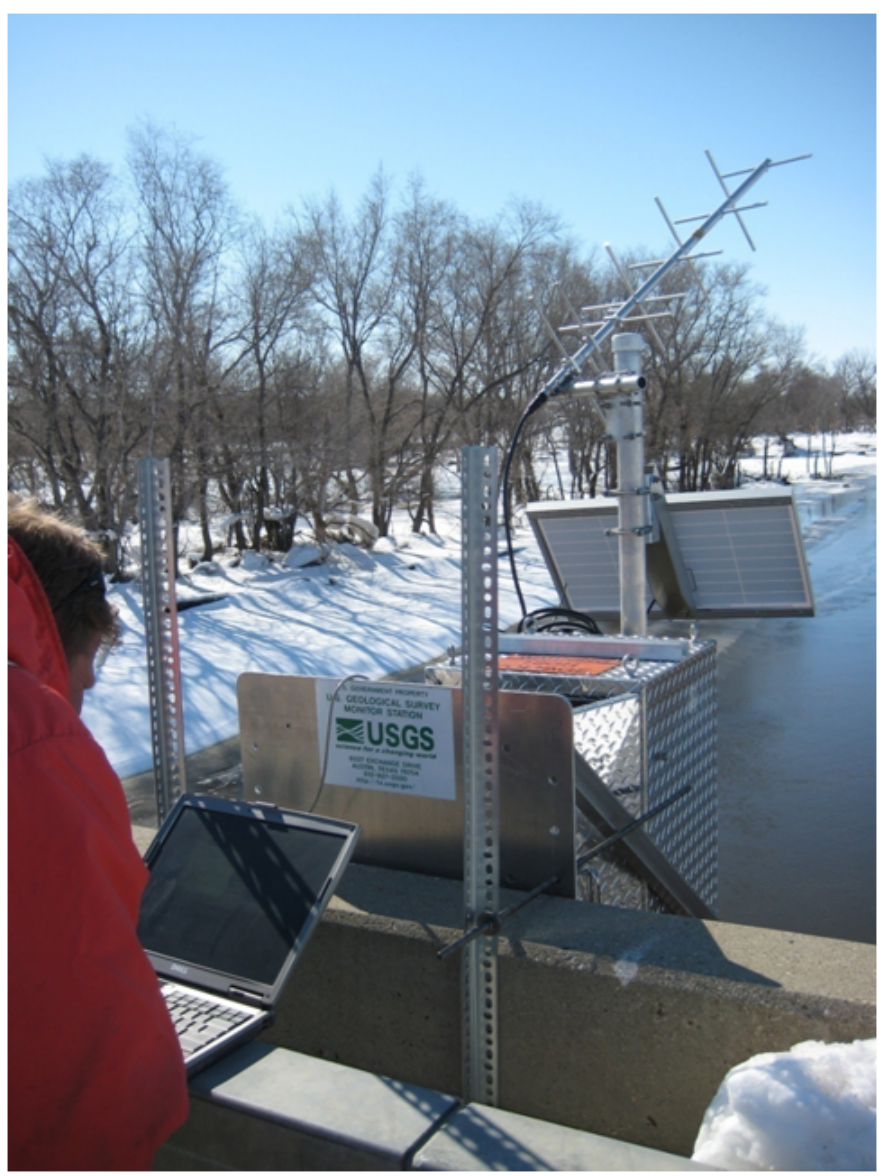

The installation of a rapid deployment gage on the James River near Adrian, North Dakota, during the spring of 2009. Fourteen of these mobile gages were placed on rivers and streams in the James River Basin to help U.S. Army Corps of Engineers track high flow in the basin. A more comprehensive view of developing flood situations can be obtained when these temporary gages are used in conjunction with permanent streamgages in a hydrologic monitoring network. Photograph by Kathleen Rowland, U.S. Geological Survey.

(Macek-Rowland, 1997, 2001a; Red River of the North Flooding - 2006, accessed January 2010 at $h t t p: / / n d . w a t e r . u s g s$. gov/photos/2006RedFlood/index.html). In the United States, the river is known officially as the Red River of the North but in Canada the river is called just the Red River. Most people living in the basin call it the Red River. For discussion purposes in this report, the river will be called the Red River but streamgages will be called by their USGS names like the "Red River of the North at Fargo, North Dakota."

The Red River is a complex river system in the northcentral plains of the United States (fig. 5). The Red River Basin within the United States includes eastern and northcentral North Dakota, western Minnesota, and a small part of the extreme northeast corner of South Dakota (fig. 1). The main part of the basin is located in Lake Agassiz Plain ecoregion with the fringes of the basin located in the Northern Glaciated Plains ecoregion in North Dakota and the Northern Minnesota Wetlands, Northern Lakes and Forests, and 
Table 5. Historical and 2009 peak of record stages and discharges for the James River subbasin in North Dakota.

[Data and footnotes in this table as well as additional station information can be found by searching on the station (site) number on the table in the U.S. Geological Survey's Water-resources data for the United States, Water Year 2009 accessed on January 2011 at $h t t p: / / w d r$ water.usgs.gov/wy2009/search.jsp. mi $^{2}$, square miles; ft, feet; $\mathrm{ft}^{3} / \mathrm{s}$, cubic feet per second; red print, peak of record; reg. regulated; na, not available]

\begin{tabular}{|c|c|c|c|c|c|c|c|c|c|c|c|c|}
\hline \multirow[b]{2}{*}{$\begin{array}{l}\text { Site } \\
\text { (fig. 4) }\end{array}$} & \multirow[b]{2}{*}{ Station name and number } & \multirow[b]{2}{*}{$\begin{array}{c}\text { Drainage } \\
\text { area } \\
\left(\mathrm{mi}^{2}\right)\end{array}$} & \multicolumn{5}{|c|}{ Maximum peaks previously known from period of record } & \multicolumn{5}{|c|}{ Maximum peaks from March to September 2009} \\
\hline & & & $\begin{array}{c}\text { Period of } \\
\text { known } \\
\text { peaks } \\
\end{array}$ & $\begin{array}{c}\text { Date of } \\
\text { peak stage }\end{array}$ & $\begin{array}{c}\text { Stage } \\
\text { (ft) }\end{array}$ & $\begin{array}{c}\text { Date of } \\
\text { peak discharge }\end{array}$ & $\begin{array}{l}\text { Discharge } \\
\left(\mathrm{ft}^{3} / \mathrm{s}\right)\end{array}$ & $\begin{array}{c}\text { Date of } \\
\text { peak stage }\end{array}$ & $\begin{array}{c}\text { Stage } \\
\text { (ft) }\end{array}$ & $\begin{array}{c}\text { Date of } \\
\text { peak discharge }\end{array}$ & $\begin{array}{l}\text { Discharge } \\
\left(\mathrm{ft}^{3} / \mathrm{s}\right)\end{array}$ & $\begin{array}{c}\text { Recurrence } \\
\text { interval } \\
\text { (years) }\end{array}$ \\
\hline 1 & $\begin{array}{l}\text { James River near } \\
\text { Grace City, N. Dak. } \\
(06468170)\end{array}$ & 1,060 & $1968-2008$ & $03 / 21 / 1996$ & ${ }^{\mathrm{a}} 16.18$ & $04 / 03 / 1997$ & b4,000 & $04 / 17 / 2009$ & 17.74 & $04 / 17 / 2009$ & 7,910 & $25-50$ \\
\hline 2 & $\begin{array}{l}\text { James River above } \\
\text { Arrowwood Lake } \\
\text { near Kensal, N. Dak. } \\
(06468250)\end{array}$ & 1,200 & $1985-2008$ & $04 / 05 / 1997$ & ${ }^{\mathrm{a}} 13.00$ & $04 / 05 / 1997$ & 4,700 & $04 / 28 / 2009$ & ${ }^{\mathrm{a}} 16.69$ & $04 / 18 / 2009$ & '8,470 & $10-25$ \\
\hline 3 & $\begin{array}{l}\text { Pipestem Creek near } \\
\text { Pingree, N. Dak. } \\
(06469400)\end{array}$ & 700 & 1973-2008 & 03/17/1995 & 11.7 & $04 / 19 / 1997$ & 3,400 & $04 / 14 / 2009$ & ${ }^{\mathrm{d}} 13.15$ & $04 / 14 / 2009$ & 9,200 & $50-100$ \\
\hline 4 & $\begin{array}{l}\text { James River at James- } \\
\text { town, N. Dak. } \\
(06470000)\end{array}$ & 2,820 & $\begin{array}{c}1928-1933 \\
1935 \\
1937-39 \\
1943-2008\end{array}$ & $04 / 11 / 1969$ & 16.94 & $05 / 13 / 1950$ & ${ }^{\mathrm{e}} 6,390$ & $05 / 04 / 2009$ & 14.13 & $05 / 04 / 2009$ & $\mathrm{f} 3,240$ & $25-50$ (reg.) \\
\hline 5 & $\begin{array}{l}\text { James River at LaMoure, } \\
\text { N. Dak. (06470500) }\end{array}$ & 4,390 & $\begin{array}{c}1903 \\
1950-2008\end{array}$ & $04 / 14 / 1969$ & 16.17 & $04 / 14 / 1969$ & 6,800 & $04 / 15 / 2009$ & 17.56 & $04 / 15 / 2009$ & ${ }^{\mathrm{f}} 12,200$ & $\begin{array}{c}100-200 \\
\text { (reg.) }\end{array}$ \\
\hline 6 & $\begin{array}{l}\text { Bear Creek near Oakes, } \\
\text { N. Dak. (06470800) }\end{array}$ & 357 & 1976-2008 & 04/03/1997 & ${ }^{\mathrm{a}} 13.24$ & $06 / 28 / 1998$ & 1,730 & $03 / 25 / 2009$ & ${ }^{\mathrm{a}} 13.43$ & $04 / 14 / 2009$ & ${ }^{\mathrm{g}} 1,900$ & $10-25$ \\
\hline 7 & $\begin{array}{l}\text { James River at ND-SD } \\
\text { State Line (06470878) }\end{array}$ & 5,480 & d2001-2008 & 04/06/1997 & h98.04 & 04/06/1997 & ${ }^{i} 7,500$ & $04 / 18 / 2009$ & h96.35 & $04 / 18 / 2009$ & ${ }^{\mathrm{j}} 11,800$ & na \\
\hline 8 & $\begin{array}{l}\text { Maple River at ND-SD } \\
\text { State Line }(06471200)\end{array}$ & 716 & 1956-2008 & 03/29/1997 & ${ }^{\mathrm{a}} 16.19$ & $04 / 11 / 1969$ & a5,930 & $03 / 24 / 2009$ & ${ }^{\mathrm{a}} 16.13$ & $03 / 24 / 2009$ & 7,000 & $25-50$ \\
\hline
\end{tabular}

${ }^{\mathrm{a} B a c k w a t e r}$ from ice, debris, aquatic vegetation, or other water resource.

${ }^{\mathrm{b}} \mathrm{Gage}$ height, 14.17 feet, backwater from ice.

${ }^{\mathrm{c}} \mathrm{Gage}$ height, 14.70 feet.

${ }^{\mathrm{d}}$ From floodmark in gage house.

${ }^{\text {eSite }}$ and datum then in use, gage height 15.82 feet.

fDischarge affected by regulation or diversion.

${ }^{g}$ Gage height, 12.25 feet.

${ }^{\text {h} F r o m ~ h i g h-w a t e r ~ m a r k ~ a t ~ p r e s e n t ~ l o c a t i o n . ~}$

'October 1981 to September 2001 equivalent discharge site formerly published as James River at Dakota Lake Dam near Ludden, N. Dak (06470875).

Gage height, 96.35 feet, from floodmark. 
North Central Hardwood Forests ecoregions in Minnesota (fig. 3). The basin is relatively flat and has a shallow river channel. The Red River is one of the few rivers in the United States to flow directly north (Macek-Rowland and others, 2001c). Originating at the confluence of the Bois de Sioux and Otter Tail Rivers in the United States, it meanders for about 400 miles northward through the Red River Valley forming the border between the States of Minnesota and North Dakota before continuing into Manitoba, Canada. Once it leaves the United States, the Red River flows north for about 150 more miles through Winnipeg, Manitoba in Canada and into Lake Winnipeg (fig. 5).

At the international boundary near Emerson, Manitoba, the drainage area of the Red River Basin is about 40,200 $\mathrm{mi}^{2}$. Because of the northerly flow, the small slope of the basin, and the shallow river channel, the timing of spring thaw and snowmelt can substantially aggravate flooding. Snow in the headwaters of the Red River Basin generally begins to melt first while areas downstream remain largely frozen. This melt pattern can cause ice jams to form, and subsequent backwater can occur as flow moves north toward the ice jams and frozen river channel.

Within the part of the Red River Basin in North Dakota, western Minnesota, and northeastern South Dakota there are several smaller rivers and streams with their own basins that are tributaries to the Red River. These smaller basins, like the Sheyenne River, Devils Lake, and Souris River, are considered subbasins to the Red River Basin. Selected subbasins of the Red River Basin in which major flooding occurred are discussed in the next sections of this report. Some other smaller rivers and streams within the Red River subbasin that sustained recorded flooding in the spring of 2009 also are discussed in the Red River of the North subbasin section of this report.

\section{Red River of the North Subbasin}

Spring flooding has become nearly routine to the residents of the Red River Basin because of major flooding that occurred in 1997, 2001, 2006, and again in 2009. The effects from flooding can be, at times, quite severe in this relatively flat basin. In 1997, the cities of Grand Forks, and East Grand Forks, Minn., were inundated with water causing both cities to be evacuated. A fire in downtown Grand Forks damaged several buildings during the height of the flooding. In the aftermath, these cities took steps to introduce flood control measures to prevent the effects from such an event in the future (Macek-Rowland, 2001).

Excessive snowfall during the winter of 2008-09 followed by additional spring moisture in 2009 caused the Red River to remain above flood level in many places for nearly 2 months. In the Red River Basin, 14 peak of record stages and 10 peak of record discharges were recorded at several locations (fig. 5, table 6).

In 2009, flooding occurred at all of the streamgages on the main-stem Red River. On March 26, 2009, the peak discharge of the Red River of the North at Hickson, N. Dak., (site 9 , fig. 5, table 6), was $23,700 \mathrm{ft}^{3} / \mathrm{s}$. The recurrence interval range for the peak discharge was not available for this streamgage (new rating curve is being developed by cooperators); however, the 2009 peak stage was $39.04 \mathrm{ft}$, which was 1.44 feet greater than the 1997 peak stage of $37.60 \mathrm{ft}$.

Two of the larger cities affected by the Red River flood in 2009 were Fargo, (population 95,500) (North Dakota Data Census Center, City Census Data, accessed January 2010 at http://www.ndsu.nodak.edu/sdc/data/census.htm) and Moorhead, Minn., (population 36,600) (Minnesota Department of Administration, State Demographic Center, accessed Janu-

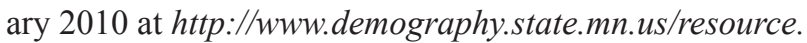
html? Id=19243) (fig. 5). The Fargo-Moorhead area received record snowfall of 28.1 inches for March 2009 adding to the above-average snowfall already on the ground (U.S. Department of Commerce, National Oceanic and Atmospheric Administration, National Environmental Satellite, Data and Information Service, 2009b). The flooding was exacerbated by the warm temperatures and heavy rainfall with 2.79 inches of rain falling within a 4-day period (March 22-25) in March. Additional moisture from snowstorms in late March and early April caused the Red River to remain above flood stage for nearly 2 months.

On March 28, 2009, the peak discharge of the Red River of the North at Fargo, N. Dak., (site 13, fig. 5, table 6) was $29,500 \mathrm{ft}^{3} / \mathrm{s}$, which was $1,500 \mathrm{ft}^{3} / \mathrm{s}$ more than the peak of record discharge set in 1997. The recurrence interval range for the 2009 peak discharge was $50-100$ years. The peak stage was $40.84 \mathrm{ft}$, which was $1.12 \mathrm{ft}$ more than the 1997 peak stage of $39.72 \mathrm{ft}$. The hydrograph (fig. 6) shows the stage (or gage height) for the Red River of the North at Fargo remained above the National Weather Service's flood stage for nearly 2 months in 2009. A secondary crest occurred at Fargo and at other sites in the region. The second crest was the result of the additional rain and snowfall that occurred during the flooding.

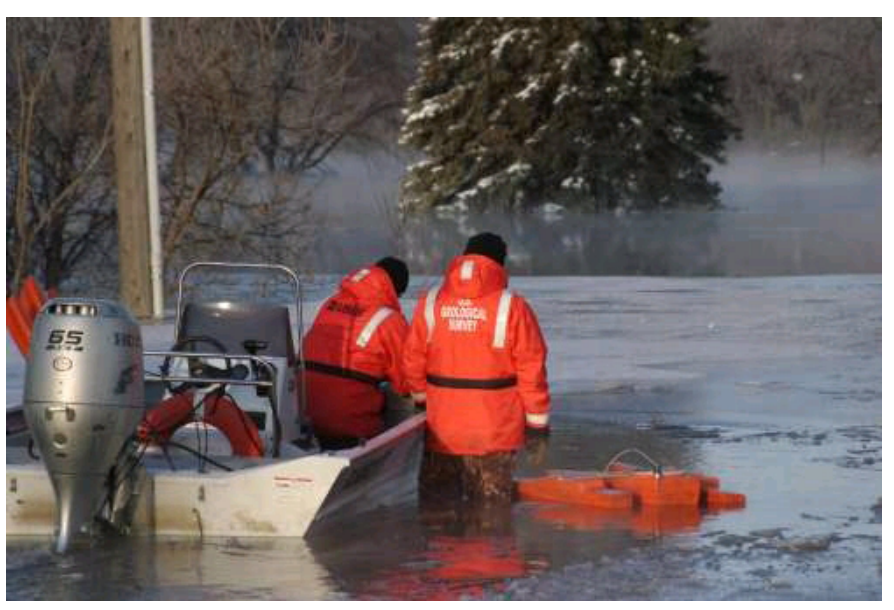

U.S. Geological Survey personnel prepare to measure historic flooding in Fargo, North Dakota, March 27, 2009. Photograph by Jennifer LaVista, U.S. Geological Survey. 


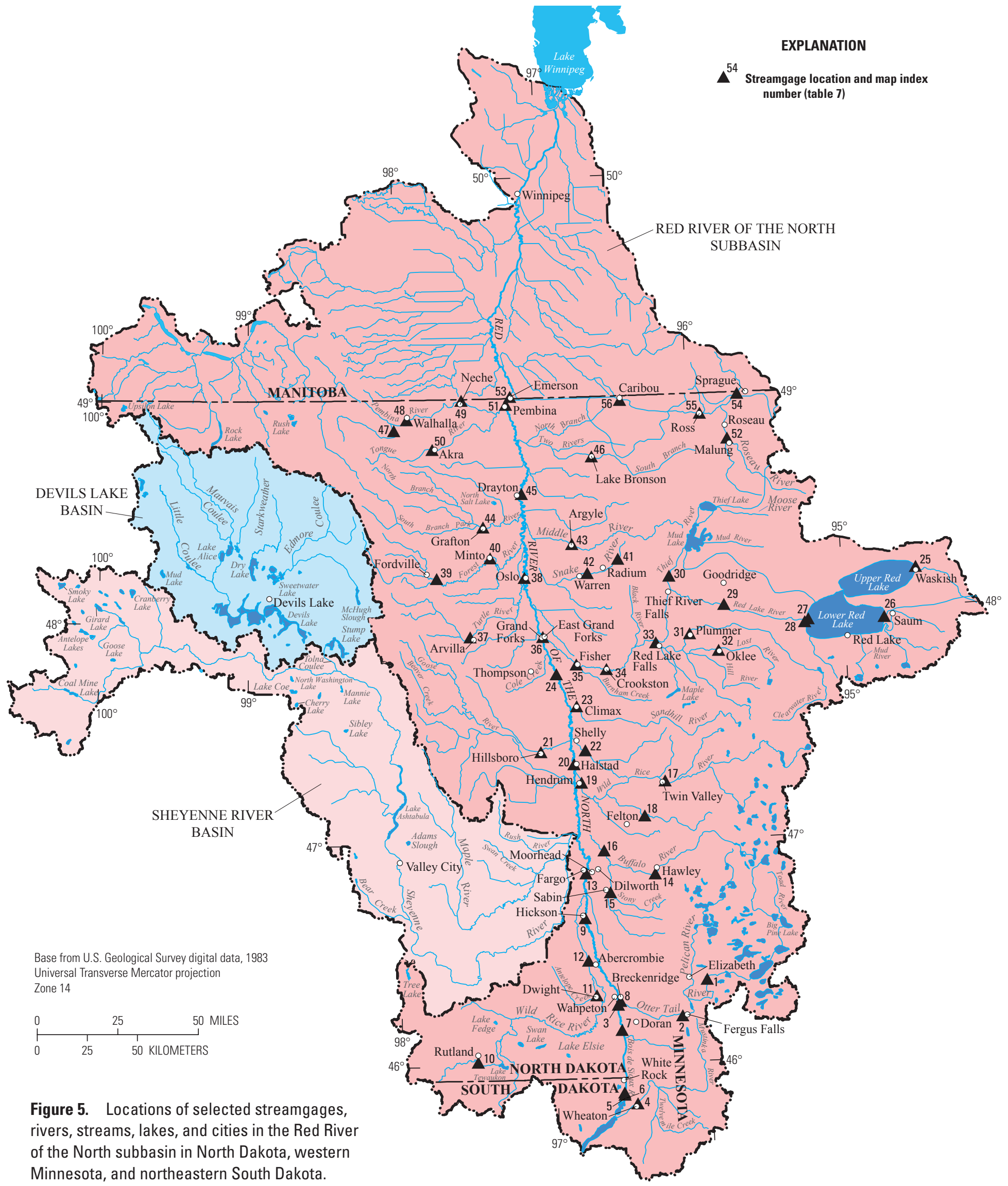


Table 6. Historical and 2009 peak of record stages and discharges for the Red River of the North subbasin in North Dakota, western Minnesota, and northeastern South Dakota.

[Data and footnotes in this table as well as additional station information can be found by searching on the station (site) number on the table in the U.S. Geological Survey's Water-resources data for the United States, Water Year 2009 accessed on January 2011 at $h t t p: / / w d r$ water.usgs.gov/wy2009/search.jsp. $\mathrm{mi}^{2}$, square miles; ft, feet; ftº, cubic feet per second; red print, peak of record; >, greater than; na, not available; reg., regulated: $<$, less than]

\begin{tabular}{|c|c|c|c|c|c|c|c|c|c|c|c|c|}
\hline \multirow[b]{2}{*}{$\begin{array}{l}\text { Site } \\
\text { (fig. 5) }\end{array}$} & \multirow[b]{2}{*}{ Station name and number } & \multirow[b]{2}{*}{$\begin{array}{l}\text { Drainage } \\
\text { area } \\
\left(\mathrm{mi}^{2}\right)\end{array}$} & \multicolumn{5}{|c|}{ Maximum peaks previously known from period of record } & \multicolumn{5}{|c|}{ Maximum peaks from March to September 2009} \\
\hline & & & $\begin{array}{l}\text { Period of } \\
\text { known } \\
\text { peaks }\end{array}$ & $\begin{array}{l}\text { Date of } \\
\text { peak stage }\end{array}$ & $\begin{array}{c}\text { Stage } \\
\text { (ft) }\end{array}$ & $\begin{array}{c}\text { Date of } \\
\text { peak discharge }\end{array}$ & $\begin{array}{l}\text { Discharge } \\
\left(\mathrm{ft}^{3} / \mathrm{s}\right)\end{array}$ & $\begin{array}{c}\text { Date of } \\
\text { peak stage }\end{array}$ & $\begin{array}{l}\text { Stage } \\
\text { (ft) }\end{array}$ & $\begin{array}{c}\text { Date of } \\
\text { peak discharge }\end{array}$ & $\begin{array}{l}\text { Discharge } \\
\left(\mathrm{ft}^{3} / \mathrm{s}\right)\end{array}$ & $\begin{array}{c}\text { Recurrence } \\
\text { interval } \\
\text { (years) }\end{array}$ \\
\hline 1 & $\begin{array}{l}\text { Otter Tail River near Elizabeth, } \\
\text { Minn. }(05030500)\end{array}$ & 1,230 & $\begin{array}{l}1904-1917 \\
1992-2008\end{array}$ & $05 / 23 / 2001$ & 9.37 & $05 / 23 / 2001$ & ${ }^{\mathrm{a}} 1,170$ & 05/01/2009 & 9.66 & $05 / 01 / 2009$ & 1,330 & $25-50$ \\
\hline 2 & $\begin{array}{l}\text { Otter Tail River below Orwell } \\
\text { Dam near Fergus Falls, } \\
\text { Minn. }(05046000)\end{array}$ & 1,740 & $1930-2008$ & $06 / 17 / 1953$ & ${ }^{\mathrm{b}} 5.60$ & $05 / 29 / 2001$ & 2,040 & $04 / 23 / 2009$ & 5.25 & $04 / 23 / 2009$ & ${ }^{\mathrm{a}} 2,020$ & $>100$ \\
\hline 3 & $\begin{array}{l}\text { Otter Tail River Diversion } \\
\text { at Breckenridge, Minn. } \\
(05046475)\end{array}$ & na & $2005-2008$ & $04 / 01 / 2006$ & 17.73 & $04 / 01 / 2006$ & 3,540 & 03/24/2009 & 20.32 & 03/24/2009 & a 5,400 & na \\
\hline 4 & $\begin{array}{l}\text { Mustinka River above } \\
\text { Wheaton, Minn. } \\
(05049000)\end{array}$ & 810 & $\begin{array}{l}1915-1924 \\
1930-1958 \\
1985-2007\end{array}$ & 04/07/1997 & 97.40 & $04 / 09 / 2001$ & 11,000 & 03/25/2009 & 93.90 & 03/25/2009 & 7,260 & $10-25$ \\
\hline 5 & $\begin{array}{l}\text { Mud Lake above White Rock } \\
\text { Dam near White Rock, } \\
\text { S. Dak. (05049995) }\end{array}$ & na & 2000-2008 & $04 / 29 / 2001$ & 80.90 & $04 / 29 / 2001$ & na & 03/30/2009 & 80.21 & 03/30/2009 & na & na \\
\hline 6 & $\begin{array}{l}\text { Bois de Sioux River near } \\
\text { White Rock, S. Dak. } \\
(05050000)\end{array}$ & 1,160 & 1941-2008 & 04/20/1997 & 16.90 & $04 / 20 / 1997$ & ${ }^{c} 8,750$ & 04/01/2009 & 15.03 & 04/01/2009 & 3,850 & $25-50$ \\
\hline 7 & $\begin{array}{l}\text { Bois de Sioux River near } \\
\text { Doran, Minn. (05051300) }\end{array}$ & 1,880 & 1989-2008 & 04/16/1997 & 24.42 & $04 / 16 / 1997$ & 12,300 & 03/26/2009 & 24.05 & 03/26/2009 & a8,340 & $10-25$ \\
\hline 8 & $\begin{array}{l}\text { Red River of the North at } \\
\text { Wahpeton, N. Dak. } \\
(05051500)\end{array}$ & 4,010 & $\begin{array}{c}1897 \\
1942-2008\end{array}$ & 04/06/1997 & b,d 19.42 & $04 / 15 / 1997$ & 12,800 & 03/24/2009 & 17.50 & 03/24/2009 & ${ }^{\mathrm{e}} 10,400$ & 50 \\
\hline 9 & $\begin{array}{l}\text { Red River of the North } \\
\text { at Hickson, N. Dak. } \\
(05051522)\end{array}$ & 4,300 & $1975-2008$ & 04/16/1997 & 37.60 & 04/14/1997 & ${ }^{\mathrm{a}} 13,300$ & 03/26/2009 & 39.04 & 03/26/2009 & 23,700 & na \\
\hline 10 & $\begin{array}{l}\text { Wild Rice River near Rutland, } \\
\text { N, Dak. }(05051600)\end{array}$ & 546 & 1959-2008 & 04/03/1997 & 10.11 & 04/03/1997 & 2,700 & 03/24/2009 & 9.54 & 03/24/2009 & 1,290 & $10-25$ \\
\hline 11 & $\begin{array}{l}\text { Antelope Creek at Dwight, } \\
\text { N. Dak. }(05052500)\end{array}$ & 294 & $\begin{array}{c}1944-1949 \\
1950-1973 \\
1975 \\
1995-2002 \\
2003-2008\end{array}$ & $04 / 10 / 1969$ & ${ }^{\mathrm{f}} 43.90$ & 04/10/1969 & 9,000 & 03/23/2009 & 42.14 & $03 / 23 / 2009$ & 9,490 & $25-50$ \\
\hline 12 & $\begin{array}{l}\text { Wild Rice River near } \\
\text { Abercrombie, N. Dak. } \\
(05053000)\end{array}$ & 2,080 & $\begin{array}{c}1897 \\
1932-2008\end{array}$ & 1897 & $\mathrm{~g} 27.50$ & $04 / 11 / 1969$ & 9,540 & 03/25/2009 & 27.78 & 03/25/2009 & 14,100 & 25-50 (reg.) \\
\hline 13 & $\begin{array}{l}\text { Red River of the North at } \\
\text { Fargo, N. Dak. (05054000) }\end{array}$ & 6,800 & $\begin{array}{l}18821897 \\
1901-2001\end{array}$ & 04/07/1897 & $\mathrm{g} 40.10$ & 04/17/1997 & 28,000 & 03/28/2009 & 40.84 & 03/28/2009 & 29,500 & $50-100$ \\
\hline 14 & $\begin{array}{l}\text { Buffalo River near Hawley, } \\
\text { Minn. }(05061000)\end{array}$ & 325 & $\begin{array}{c}1921 \\
1945-2008\end{array}$ & $06 / 22 / 2000$ & 10.86 & $04 / 01 / 2006$ & 2,420 & 03/25/2009 & 10.60 & 03/25/2009 & 2,270 & $10-25$ \\
\hline 15 & $\begin{array}{l}\text { South Branch Buffalo River at } \\
\text { Sabin, Minn. }(05061500)\end{array}$ & 454 & 1945-2008 & $07 / 02 / 1975$ & 19.90 & $07 / 02 / 1975$ & 8,500 & 03/25/2009 & 19.08 & $03 / 25 / 2009$ & 7,280 & $25-50$ \\
\hline
\end{tabular}


Table 6. Historical and 2009 peak of record stages and discharges for the Red River of the North subbasin in North Dakota, western Minnesota, and northeastern South Dakota.-Continued

[Data and footnotes in this table as well as additional station information can be found by searching on the station (site) number on the table in the U.S. Geological Survey's Water-resources data for the United States, Water Year 2009 accessed on January 2011 at $h t t p: / / w d r$ water.usgs.gov/wy2009/search.jsp. $\mathrm{mi}^{2}$, square miles; ft, feet; $\mathrm{ft}^{3} / \mathrm{s}$, cubic feet per second; red print, peak of record; >, greater than; na, not available; reg., regulated: $<$, less than]

\begin{tabular}{|c|c|c|c|c|c|c|c|c|c|c|c|c|}
\hline \multirow[b]{2}{*}{$\begin{array}{l}\text { Site } \\
\text { (fig. 5) }\end{array}$} & \multirow[b]{2}{*}{ Station name and number } & \multirow[b]{2}{*}{$\begin{array}{l}\text { Drainage } \\
\text { area } \\
\left(\mathrm{mi}^{2}\right)\end{array}$} & \multicolumn{5}{|c|}{ Maximum peaks previously known from period of record } & \multicolumn{5}{|c|}{ Maximum peaks from March to September 2009} \\
\hline & & & $\begin{array}{l}\text { Period of } \\
\text { known } \\
\text { peaks }\end{array}$ & $\begin{array}{c}\text { Date of } \\
\text { peak stage }\end{array}$ & $\begin{array}{c}\text { Stage } \\
\text { (ft) }\end{array}$ & $\begin{array}{c}\text { Date of } \\
\text { peak discharge }\end{array}$ & $\begin{array}{l}\text { Discharge } \\
\left(\mathrm{ft}^{3} / \mathrm{s}\right)\end{array}$ & $\begin{array}{c}\text { Date of } \\
\text { peak stage }\end{array}$ & $\begin{array}{c}\text { Stage } \\
\text { (ft) }\end{array}$ & $\begin{array}{c}\text { Date of } \\
\text { peak discharge }\end{array}$ & $\begin{array}{c}\text { Discharge } \\
\left(\mathrm{ft}^{3} / \mathbf{s}\right)\end{array}$ & $\begin{array}{l}\text { Recurrence } \\
\text { interval } \\
\text { (years) }\end{array}$ \\
\hline 16 & $\begin{array}{l}\text { Buffalo River near Dilworth, } \\
\text { Minn. (05062000) }\end{array}$ & 975 & $1931-2008$ & $07 / 02 / 1975$ & 27.10 & $07 / 02 / 1975$ & 13,600 & $03 / 25 / 2009$ & 25.86 & $03 / 25 / 2009$ & ${ }^{\mathrm{h}} 11,400$ & $50-100$ \\
\hline 17 & $\begin{array}{l}\text { Wild Rice River at Twin } \\
\text { Valley, Minn. (05062500) }\end{array}$ & 934 & $\begin{array}{l}1909-1917 \\
1930-1983 \\
1989-2008\end{array}$ & $06 / 24 / 2002$ & ${ }^{\mathrm{i}} 17.96$ & $06 / 24 / 2002$ & 20,300 & $03 / 25 / 2009$ & ${ }^{\mathrm{b}} 13.53$ & $03 / 25 / 2009$ & ${ }^{\mathrm{j}, \mathrm{k}, \mathrm{l}} 6,700$ & $10-25$ \\
\hline 18 & $\begin{array}{l}\text { South Branch Wild Rice River } \\
\text { at County Road } 27 \text { near } \\
\text { Felton, Minn. }(05063398)\end{array}$ & na & $2004-2008$ & $03 / 31 / 2006$ & 10.94 & $03 / 31 / 2006$ & 5,490 & $03 / 25 / 2009$ & 10.79 & $03 / 25 / 2009$ & 5,080 & na \\
\hline 19 & $\begin{array}{l}\text { Wild Rice River at Hendrum, } \\
\text { Minn. }(05064000)\end{array}$ & 1,560 & $1944-2008$ & $04 / 18 / 1997$ & ${ }^{\mathrm{m}} 33.85$ & $04 / 18 / 1997$ & ${ }^{\mathrm{n}} 10,600$ & 03/29/2009 & $\mathrm{m} 33.56$ & 03/29/2009 & ${ }^{\circ} 9,440$ & $10-25$ \\
\hline 20 & $\begin{array}{l}\text { Red River of the North at } \\
\text { Halstad, Minn. }(05064500)\end{array}$ & 21,800 & $\begin{array}{l}1936-1937 \\
1942-2008\end{array}$ & 04/19/1997 & 40.74 & 04/19/1997 & 71,500 & 03/30/2009 & 40.63 & 03/30/2009 & 67,400 & $50-100$ \\
\hline 21 & $\begin{array}{l}\text { Goose River at Hillsboro, } \\
\text { N. Dak. (05066500) }\end{array}$ & 1,203 & 1931-2008 & $04 / 21 / 1979$ & 16.76 & $04 / 21 / 1979$ & 14,800 & $03 / 25 / 2009$ & ${ }^{\mathrm{b}} 16.67$ & 03/25/2009 & 8,700 & $10-25$ \\
\hline 22 & $\begin{array}{l}\text { Marsh River near Shelly, } \\
\text { Minn. (05067500) }\end{array}$ & 220 & $\begin{array}{l}1944-1983 \\
1985-2008\end{array}$ & 04/18/1997 & $\mathrm{d} 25.45$ & $04 / 03 / 2006$ & 6,390 & $03 / 25 / 2009$ & $\mathrm{~m} 24.95$ & 03/26/2009 & l,m,p 5,000 & na \\
\hline 23 & $\begin{array}{l}\text { Sand Hill River at Climax, } \\
\text { Minn. (05069000) }\end{array}$ & 420 & $1943-2001$ & $04 / 14 / 1965$ & $\mathrm{~m} 39.40$ & $04 / 14 / 1965$ & q4,560 & $04 / 01 / 2009$ & $\mathrm{~b}, \mathrm{~d} 33.43$ & $04 / 01 / 2009$ & 13,400 & $5-10$ \\
\hline 24 & $\begin{array}{l}\text { Red River of the North } \\
\text { near Thompson, N. Dak. } \\
(05070000)\end{array}$ & 24,010 & 1999-2008 & $04 / 07 / 2006$ & 60.92 & $04 / 07 / 2006$ & a 53,500 & $04 / 01 / 2009$ & 64.56 & $04 / 01 / 2009$ & 61,300 & na \\
\hline 25 & $\begin{array}{l}\text { Upper Red Lake at Waskish, } \\
\text { Minn. }(05073500)\end{array}$ & na & $\begin{array}{l}1921-1929 \\
1930-1933 \\
1940-1946 \\
1995-2008\end{array}$ & $06 / 28 / 1943$ & 78.34 & $06 / 28 / 1943$ & na & $05 / 27 / 2009$ & 76.86 & $05 / 27 / 2009$ & na & na \\
\hline 26 & $\begin{array}{l}\text { Lower Red Lake at Battle } \\
\text { River Mouth near Saum, } \\
\text { Minn. (05073650) }\end{array}$ & na & $1996-2008$ & 08/09/2001 & 76.75 & $08 / 09 / 2001$ & na & $06 / 28 / 2009$ & 76.31 & $06 / 25 / 2009$ & na & na \\
\hline 27 & $\begin{array}{l}\text { Lower Red Lake near Red } \\
\text { Lake, Minn. (05074000) }\end{array}$ & 1,950 & $\begin{array}{l}1930-1932 \\
1933-1997 \\
1999-2008\end{array}$ & $06 / 25 / 1950$ & 78.53 & $06 / 25 / 1950$ & na & $05 / 25 / 2009$ & 76.30 & $05 / 25 / 2009$ & na & na \\
\hline 28 & $\begin{array}{l}\text { Red Lake River near Red } \\
\text { Lake, Minn. (05074500) }\end{array}$ & 1,950 & $\begin{array}{l}1933-1994 \\
1999-2008\end{array}$ & $06 / 25 / 1950$ & 78.19 & $06 / 25 / 1950$ & 3,600 & 03/11/2009 & 72.35 & $08 / 15 / 2009$ & г741 & 2 \\
\hline 29 & $\begin{array}{l}\text { Red Lake River at High Land- } \\
\text { ing near Goodridge, Minn. } \\
(05075000)\end{array}$ & 2,300 & 1929-2008 & $07 / 07 / 1975$ & 13.39 & $07 / 07 / 1975$ & 4,060 & $03 / 25 / 2009$ & ${ }^{\mathrm{b}} 13.61$ & $03 / 25 / 2009$ & a,b.j.j2,190 & $<5$ \\
\hline
\end{tabular}


Table 6. Historical and 2009 peak of record stages and discharges for the Red River of the North subbasin in North Dakota, western Minnesota, and northeastern South Dakota.-Continued

[Data and footnotes in this table as well as additional station information can be found by searching on the station (site) number on the table in the U.S. Geological Survey's Water-resources data for the United States, Water Year 2009 accessed on January 2011 at $h t t p: / / w d r$ water.usgs.gov/wy2009/search.jsp. $\mathrm{mi}^{2}$, square miles; ft, feet; fts, cubic feet per second; red print, peak of record; >, greater than; na, not available; reg., regulated: $<$, less than]

\begin{tabular}{|c|c|c|c|c|c|c|c|c|c|c|c|c|}
\hline \multirow[b]{2}{*}{$\begin{array}{l}\text { Site } \\
\text { (fig. 5) }\end{array}$} & \multirow[b]{2}{*}{ Station name and number } & \multirow[b]{2}{*}{$\begin{array}{l}\text { Drainage } \\
\text { area } \\
\left(\mathrm{mi}^{2}\right)\end{array}$} & \multicolumn{5}{|c|}{ Maximum peaks previously known from period of record } & \multicolumn{5}{|c|}{ Maximum peaks from March to September 2009} \\
\hline & & & $\begin{array}{l}\text { Period of } \\
\text { known } \\
\text { peaks }\end{array}$ & $\begin{array}{l}\text { Date of } \\
\text { peak stage }\end{array}$ & $\begin{array}{l}\text { Stage } \\
\text { (ft) }\end{array}$ & $\begin{array}{l}\text { Date of } \\
\text { peak discharge }\end{array}$ & $\begin{array}{l}\text { Discharge } \\
\left(\mathrm{ft}^{3} / \mathrm{s}\right)\end{array}$ & $\begin{array}{l}\text { Date of } \\
\text { peak stage }\end{array}$ & $\begin{array}{c}\text { Stage } \\
(\mathrm{ft})\end{array}$ & $\begin{array}{c}\text { Date of } \\
\text { peak discharge }\end{array}$ & $\begin{array}{l}\text { Discharge } \\
\left(\mathrm{ft}^{3} / \mathbf{s}\right)\end{array}$ & $\begin{array}{l}\text { Recurrence } \\
\text { interval } \\
\text { (years) }\end{array}$ \\
\hline 30 & $\begin{array}{l}\text { Thief River near Thief River } \\
\text { Falls, Minn. }(05076000)\end{array}$ & 985 & $\begin{array}{l}1909-1917 \\
1920-1921 \\
1922-1924 \\
1928-1981 \\
1982-2008\end{array}$ & $05 / 13 / 1950$ & 17.38 & 05/13/1950 & 5,610 & 04/04/2009 & b16.03 & 04/06/2009 & s3,000 & $5-10$ \\
\hline 31 & $\begin{array}{l}\text { Clearwater River at Plummer, } \\
\text { Minn. }(05078000)\end{array}$ & 555 & $\begin{array}{l}1939-1979 \\
1982-2008\end{array}$ & $04 / 01 / 2006$ & 12.82 & 04/25/1979 & 3,940 & 03/24/2009 & ${ }^{\mathrm{b}} 13.23$ & 03/24/2009 & $\mathrm{b}, \mathrm{k} 3,300$ & $10-25$ \\
\hline 32 & $\begin{array}{l}\text { Lost River at Oklee, Minn. } \\
\quad(05078230)\end{array}$ & 254 & $\begin{array}{l}1960-1981 \\
1982-2008\end{array}$ & 04/08/1997 & b16.91 & 04/11/1969 & 3,210 & 03/25/2009 & 16.92 & $03 / 25 / 2009$ & t2,800 & $10-25$ \\
\hline 33 & $\begin{array}{l}\text { Clearwater River at Red Lake } \\
\text { Falls, Minn. (05078500) }\end{array}$ & 1,380 & $\begin{array}{l}1909-1917 \\
1934-1981 \\
1982-2008\end{array}$ & 03/06/1983 & ${ }^{\mathrm{d}} 15.85$ & $04 / 25 / 1979$ & 10,300 & 03/25/2009 & 13.75 & $03 / 25 / 2009$ & 12,400 & 50 \\
\hline 34 & $\begin{array}{l}\text { Red Lake River at Crookston, } \\
\text { Minn. }(05079000)\end{array}$ & 5,270 & $\begin{array}{l}18971902 \\
1904-1920 \\
1922-2008\end{array}$ & 04/17/1997 & $\mathrm{d} 28.40$ & 04/12/1969 & 28,400 & 03/24/2009 & b25.63 & 03/25/2009 & 25,000 & $25-50$ \\
\hline 35 & $\begin{array}{l}\text { Red Lake River at Fisher, } \\
\text { Minn. }(05080000)\end{array}$ & 5,680 & 1999-2008 & $04 / 03 / 2006$ & 40.81 & 04/03/2006 & 26,400 & 03/26/2009 & b 40.64 & 03/26/2009 & 25,200 & $5-10$ \\
\hline 36 & $\begin{array}{l}\text { Red River of the North at } \\
\text { Grand Forks, N. Dak. } \\
(05082500)\end{array}$ & 30,100 & $1882-2008$ & $04 / 22 / 1997$ & $\mathrm{~d} 54.35$ & 04/18/1997 & " 137,000 & 04/01/2009 & 49.33 & 04/01/2009 & 76,700 & $10-50$ \\
\hline 37 & $\begin{array}{l}\text { Turtle River at Turtle River } \\
\text { State Park near Arvilla, } \\
\text { N. Dak. (05082625) }\end{array}$ & 311 & 1992-2008 & $06 / 13 / 2000$ & ${ }^{\mathrm{d}} 18.74$ & $06 / 13 / 2000$ & 12,400 & 03/24/2009 & 9.32 & 03/24/2009 & 1,890 & $<5$ \\
\hline 38 & $\begin{array}{l}\text { Red River of the North at Oslo, } \\
\text { Minn. }(05083500)\end{array}$ & 31,200 & $\begin{array}{l}1936-1937 \\
1941-1947 \\
1948-1960 \\
1973-1976 \\
1984-2001 \\
2002-2008\end{array}$ & 04/23/1997 & 38.00 & 04/23/1997 & 120,000 & 04/01/2009 & 38.37 & 04/01/2009 & 80,600 & na \\
\hline 39 & $\begin{array}{l}\text { Forest River near Fordville, } \\
\text { N. Dak. }(05084000)\end{array}$ & 456 & 1940-2008 & 04/18/1950 & ${ }^{\mathrm{d}} 14.48$ & $04 / 18 / 1950$ & ${ }^{\mathrm{v}} 16,400$ & 03/24/2009 & 8.45 & 03/24/2009 & 3,160 & $5-10$ \\
\hline 40 & $\begin{array}{l}\text { Forest River at Minto, N. Dak. } \\
\quad(05085000)\end{array}$ & 740 & 1944-2008 & $04 / 18 / 1950$ & ${ }^{\mathrm{d}} 11.80$ & $04 / 18 / 1950$ & ${ }^{\mathrm{w}} 16,600$ & 03/24/2009 & b, $x 8.35$ & $03 / 25 / 2009$ & $\mathrm{j}, \mathrm{y} 3,200$ & $5-10$ \\
\hline 41 & $\begin{array}{l}\text { Snake River above Radium, } \\
\text { Minn. (05085420) }\end{array}$ & na & 2004-2008 & $03 / 31 / 2006$ & b89.14 & $04 / 01 / 2006$ & 908 & & & Discontinued & & \\
\hline 42 & $\begin{array}{l}\text { Snake River above Warren, } \\
\text { Minn. }(05085450)\end{array}$ & na & 2009 & na & na & na & na & 03/24/2009 & 72.30 & $03 / 24 / 2009$ & ${ }^{\mathrm{n}} 1,880$ & na \\
\hline 43 & $\begin{array}{l}\text { Middle River at Argyle, Minn. } \\
\quad(05087500)\end{array}$ & 265 & $\begin{array}{c}1945 \\
1950-1981 \\
1982-2008\end{array}$ & 05/19/1996 & ${ }^{\mathrm{d}} 18.27$ & 05/19/1996 & 5,020 & 06/30/2009 & ${ }^{\mathrm{z}} 14.98$ & 06/30/2009 & 1,880 & 5 \\
\hline
\end{tabular}


Table 6. Historical and 2009 peak of record stages and discharges for the Red River of the North subbasin in North Dakota, western Minnesota, and northeastern South Dakota.-Continued

[Data and footnotes in this table as well as additional station information can be found by searching on the station (site) number on the table in the U.S. Geological Survey's Water-resources data for the United States, Water Year 2009 accessed on January 2011 at $h t t p: / / w d r$ water.usgs.gov/wy2009/search.jsp. $\mathrm{mi}^{2}$, square miles; ft, feet; $\mathrm{ft}^{3} / \mathrm{s}$, cubic feet per second; red print, peak of record; >, greater than; na, not available; reg., regulated: $<$, less than]

\begin{tabular}{|c|c|c|c|c|c|c|c|c|c|c|c|c|}
\hline \multirow[b]{2}{*}{$\begin{array}{l}\text { Site } \\
\text { (fig. 5) }\end{array}$} & \multirow[b]{2}{*}{ Station name and number } & \multirow[b]{2}{*}{$\begin{array}{l}\text { Drainage } \\
\text { area } \\
\left(\mathrm{mi}^{2}\right)\end{array}$} & \multicolumn{5}{|c|}{ Maximum peaks previously known from period of record } & \multicolumn{5}{|c|}{ Maximum peaks from March to September 2009} \\
\hline & & & $\begin{array}{l}\text { Period of } \\
\text { known } \\
\text { peaks }\end{array}$ & $\begin{array}{l}\text { Date of } \\
\text { peak stage }\end{array}$ & $\begin{array}{c}\text { Stage } \\
\text { (ft) }\end{array}$ & $\begin{array}{c}\text { Date of } \\
\text { peak discharge }\end{array}$ & $\begin{array}{l}\text { Discharge } \\
\left(\mathrm{ft}^{3} / \mathrm{s}\right)\end{array}$ & $\begin{array}{c}\text { Date of } \\
\text { peak stage }\end{array}$ & $\begin{array}{l}\text { Stage } \\
\text { (ft) }\end{array}$ & $\begin{array}{c}\text { Date of } \\
\text { peak discharge }\end{array}$ & $\begin{array}{c}\text { Discharge } \\
\left(\mathrm{ft}^{3} / \mathbf{s}\right)\end{array}$ & $\begin{array}{l}\text { Recurrence } \\
\text { interval } \\
\text { (years) }\end{array}$ \\
\hline 44 & $\begin{array}{l}\text { Park River at Grafton, N. Dak. } \\
(05090000)\end{array}$ & 695 & $1931-2008$ & $04 / 19 / 1950$ & aa20.13 & $04 / 19 / 1950$ & ${ }^{\mathrm{bb}} 12,600$ & $04 / 16 / 2009$ & 15.71 & $04 / 16 / 2009$ & 5,090 & 5-10 (reg.) \\
\hline 45 & $\begin{array}{l}\text { Red River of the North } \\
\text { at Drayton, N. Dak. } \\
(05092000)\end{array}$ & 34,800 & $\begin{array}{c}1936-37 \\
1941-2001\end{array}$ & 04/24/1997 & 45.55 & 04/24/1997 & 124,000 & $04 / 06 / 2009$ & 43.82 & 04/05/2009 & $\mathrm{j}, \mathrm{m}, \mathrm{cc} 85,500$ & $10-50$ \\
\hline 46 & $\begin{array}{l}\text { South Branch Two Rivers } \\
\text { at Lake Bronson, Minn. } \\
(05094000)\end{array}$ & 422 & $\begin{array}{l}1928-1936 \\
1941-1947 \\
1953-1981 \\
1985-2008\end{array}$ & 04/05/1966 & 18.23 & $04 / 05 / 1966$ & 5,410 & $04 / 15 / 2009$ & dd 11.30 & $04 / 15 / 2009$ & 2,790 & $5-10$ \\
\hline 47 & $\begin{array}{l}\text { Little South Pembina River } \\
\text { near Walhalla, N. Dak. } \\
(05099400)\end{array}$ & 182 & $\begin{array}{l}1956-1982 \\
2000-2008\end{array}$ & $04 / 25 / 1970$ & 13.95 & $04 / 25 / 1970$ & 6,600 & 04/13/2009 & 9.02 & 04/13/2009 & 2,620 & $<5$ \\
\hline 48 & $\begin{array}{l}\text { Pembina River at Walhalla, } \\
\text { N. Dak. }(05099600)\end{array}$ & 3,350 & $\begin{array}{l}1939-1990 \\
2000-2008\end{array}$ & $04 / 18 / 1950$ & ${ }^{\mathrm{ee}} 16.20$ & $04 / 18 / 1950$ & ff 20,400 & 04/19/2009 & 16.63 & 04/19/2009 & 17,200 & $25-50$ \\
\hline 49 & $\begin{array}{l}\text { Pembina River at Neche, } \\
\text { N. Dak. }(05100000)\end{array}$ & 3,410 & $\begin{array}{l}1904-1908 \\
1910-1915 \\
1919-2008\end{array}$ & 04/21/1997 & b24.51 & 04/27/1997 & 15,100 & 04/20/2009 & 21.61 & 04/20/2009 & 16,900 & $50-100$ \\
\hline 50 & $\begin{array}{l}\text { Tongue River at Akra, N. Dak. } \\
\quad(05101000)\end{array}$ & 160 & $\begin{array}{c}1950 \\
1951-2008\end{array}$ & $04 / 18 / 1950$ & $\operatorname{gg} 48.7$ & $04 / 18 / 1950$ & hh 11,800 & 04/16/2009 & 17.12 & 04/16/2009 & 1,150 & $10-25$ (reg.) \\
\hline 51 & $\begin{array}{l}\text { Red River of the North at Pem- } \\
\text { bina, N. Dak. }(05102490)\end{array}$ & 40,200 & 1985-2008 & 04/26/1997 & 54.94 & $04 / 26 / 1997$ & 141,000 & $04 / 15 / 2009$ & 52.71 & $04 / 15 / 2009$ & 87,200 & na \\
\hline 52 & $\begin{array}{l}\text { Roseau River below South } \\
\text { Fork near Malung, Minn. } \\
(05104500)\end{array}$ & 430 & 1946-2008 & $06 / 12 / 2002$ & 26.96 & $06 / 12 / 2002$ & 16,000 & 03/25/2009 & b21.56 & 03/25/2009 & b., 4,600 & $5-10$ \\
\hline 53 & $\begin{array}{l}\text { Red River of the North at } \\
\text { Emerson, Manitoba, Canada } \\
(05102500)\end{array}$ & 40,200 & $\begin{array}{c}1861 \\
1902 \\
1912-1929 \\
1929-2008\end{array}$ & $04 / 26 / 1997$ & 792.41 & $04 / 26 / 1997$ & 133,000 & $04 / 15 / 2009$ & 790.76 & $04 / 15 / 2009$ & 87,900 & na \\
\hline 54 & $\begin{array}{l}\text { Sprague Creek near Sprague, } \\
\text { Manitoba, Canada } \\
(05106000)\end{array}$ & 176 & $\begin{array}{l}1928-1981 \\
1999-2008\end{array}$ & $06 / 11 / 2002$ & 17.08 & $06 / 11 / 2002$ & ii 8,440 & 04/16/2009 & 13.70 & 04/16/2009 & 1,470 & $5-10$ \\
\hline 55 & $\begin{array}{l}\text { Roseau River at Ross, Minn. } \\
\quad(05107500)\end{array}$ & 1,090 & $\begin{array}{l}1928-1991 \\
1995-2008\end{array}$ & $06 / 16 / 2002$ & 18.89 & $06 / 16 / 2002$ & 10,500 & $04 / 21 / 2009$ & 16.35 & $04 / 21 / 2009$ & 3,460 & $5-10$ \\
\hline 56 & $\begin{array}{l}\text { Roseau River below State } \\
\text { Ditch } 51 \text { near Caribou, } \\
\text { Minn. (05112000) }\end{array}$ & 1,420 & $\begin{array}{c}1917 \\
1920-2008\end{array}$ & $06 / 24 / 2002$ & 11.91 & $06 / 24 / 2002$ & 4,320 & 05/01/2009 & ${ }^{\mathrm{jj}} 10.46$ & 05/01/2009 & 3,240 & $10-25$ \\
\hline
\end{tabular}


${ }^{\mathrm{a}}$ Affected by regulation period.

${ }^{\mathrm{b} B a c k w a t e r}$ from ice, debris aquatic vegetation, or other water resource.

'Estimated from observed readings made under non-ideal conditions. Some evidence that peak occurred April 16 at a discharge of 7,930 cubic feet per second.

dFrom high-water mark.

${ }^{e}$ Red River of the North flow; with diversion flow (05046475) would be 15,000 cubic feet per second.

${ }^{t}$ Present datum, gage height, 17.82, site and datum then in use.

gExtreme outside period of record.

hFrom measurement of flow; gage height, 25.82 feet.

iFrom floodmark. Gage height, 20.00 feet, July 22, 1909; site and datum then in use

'Estimated.

${ }^{\mathrm{k}}$ Maximum daily average.

'Estimated daily mean discharge.

mBackwater from Red River of the North.

nFrom measurement.

${ }^{\circ}$ Gage height, 33.00 feet. Affected to unknown degree by diversion into Marsh River Basin. PAffected to unknown degree by regulation or diversion.

${ }^{9}$ Gage height, 17.81 feet, site and datum then in use.

${ }^{\mathrm{r}}$ Gage height, 71.91 feet.

sage height, 13.15 feet.

'Measured flow, gage height.
"Maximum observed, flow affected by breakout flow from Red River about 20 river miles upstream from gage that entered Red Lake River about 2 miles upstream from the confluence with Red River of the North.

${ }^{\vee}$ From rating curve extended above 5,600 cubic feet per second on basis of indirect measurement.

"From rating curve extended above 7,200 cubic feet per second on basis of contracted opening.

${ }^{x}$ Observed, may have been higher during period of no gage height record March 23-26.

${ }^{y}$ Gage height, 7.76 feet.

¿Peak gage height of 15.99 occurred on March 26, 2009.

${ }^{\text {aa }}$ Site and datum then in use.

${ }^{b b}$ From rating curve extended above 9,000 cubic feet per second.

${ }^{\mathrm{cc} G a g e}$ height, 43.61 feet.

ddPeak gage height of 14.58 feet from high-water mark; date unknown but most likely March 24-27.

${ }^{e e}$ From rating curve extended above 7,000 cubic feet per second on basis of contracted-opening measurement of discharge, gage height, 16.20 feet, approximate stage, from rating curve, at present location and datum; stage at site and datum then in use, 19.20 feet.

${ }^{\mathrm{ff}}$ From rating curve extended 7,000 cubic feet per second on basis of contracted-opening measurement of discharge.

ggPrior to July 1954, gage located 1.2 miles downstream at datum 30.00 feet lower than current datum

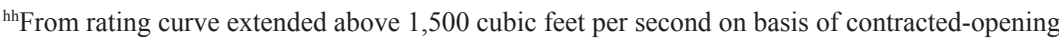
measurement of peak flow; gage height 48.70 feet; from floodmark; site and datum then in use.

ii From rating curve extension above 2,560 cubic feet per second.

ijPeak gage height of 11.42 occurred on April 7, 2009; due to backwater from ice. 


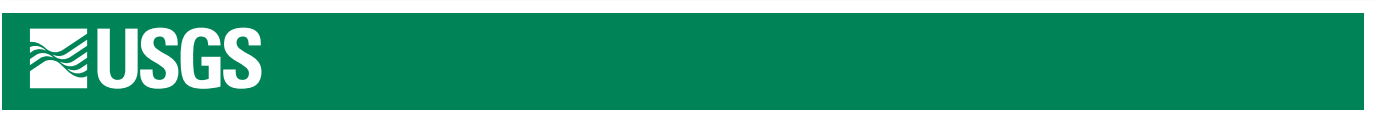

USGS 05054000 RED RIVER OF THE NORTH AT FARGO, ND

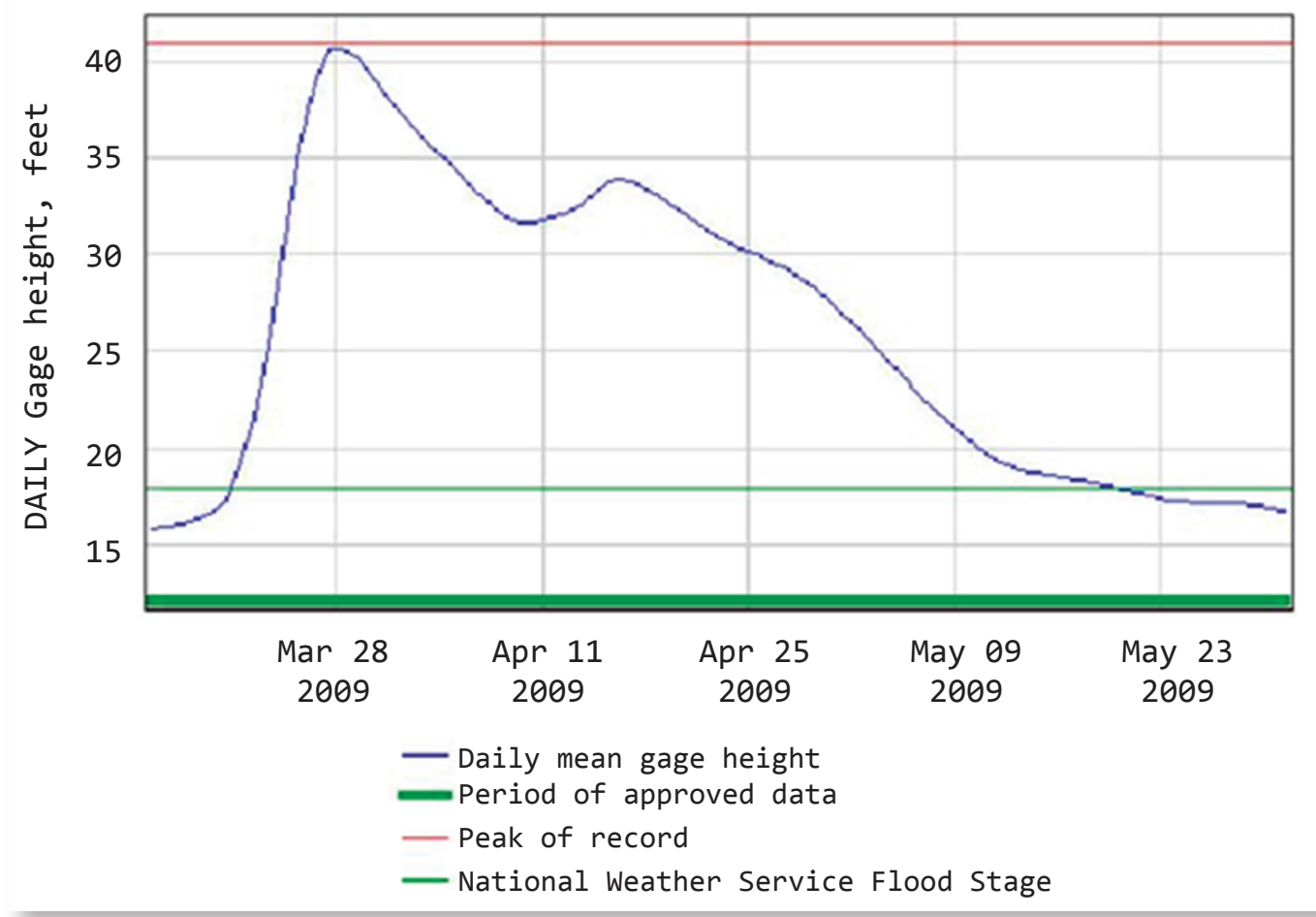

Figure 6. Website hydrograph of the Red River of the North at Fargo, North Dakota, spring 2009. Flood information like that shown in the above hydrograph can be obtained from data collected at U.S. Geological Survey streamgages at U.S. Geological Survey websites such as: http://waterdata.usgs.gov/nd.

Downstream from Fargo and Moorhead, the Red River of the North near Thompson, N. Dak., (site 24, fig. 5, table 6) recorded a peak discharge of $61,300 \mathrm{ft}^{3} / \mathrm{s}$ on April 1, 2009, and the peak stage was $64.56 \mathrm{ft}$, which was $3.18 \mathrm{ft}$ less than the 1997 peak stage of $67.74 \mathrm{ft}$ from a high watermark established by the U.S. Army Corps of Engineers, 1997 (U.S. Geological Survey, 2009). The recurrence interval range for the 2009 peak discharge was not available for this streamgage (new rating curve is being developed by cooperators).

On April 1, 2009, the peak discharge of the Red River of the North at Grand Forks, N. Dak., (site 36, fig. 5, table 6), was $76,700 \mathrm{ft}^{3} / \mathrm{s}$. The recurrence interval range for the 2009 peak discharge was $10-50$ years. The 2009 peak stage was $49.33 \mathrm{ft}$, which was $5.02 \mathrm{ft}$ less than the 1997 peak stage of $54.35 \mathrm{ft}$. The 2009 peak stage was the third highest stage recorded for this streamgage in 126 years of record. The 2009 flood did not have nearly the effect that the 1997 flood on the cities of Grand Forks-East Grand Forks because, in part, flood control measures (such as flood walls and levees) were installed to protect these two cites after the 1997 flood (K. Johnson, U.S. Army Corps of Engineers, written commun., March 2009).

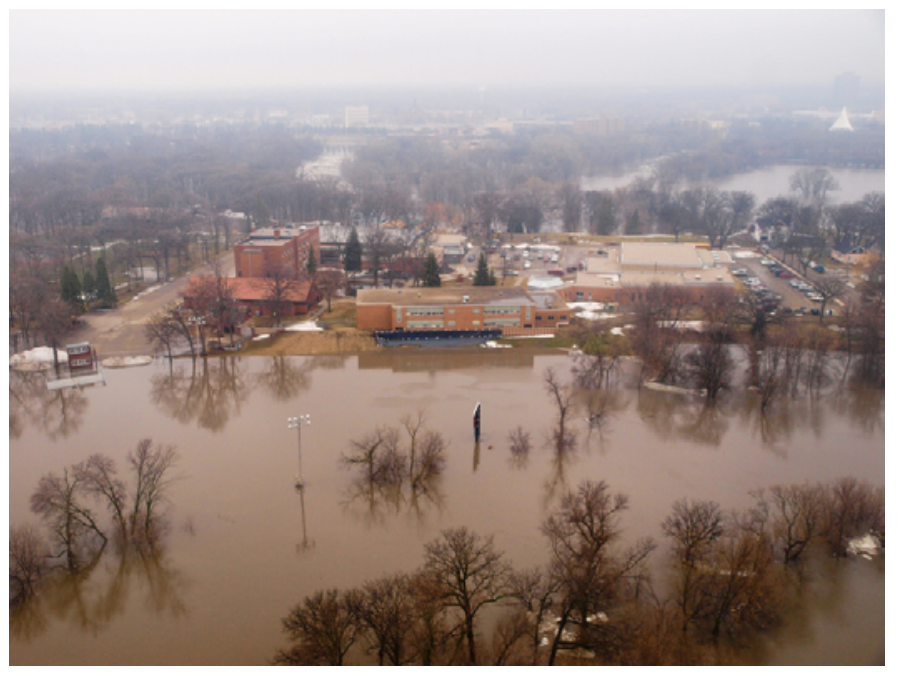

U.S. Coast Guard flyover to survey flooding in Fargo, North Dakota, March 24, 2009. Photograph by Michael Rieger, Federal Emergency Management Agency. 


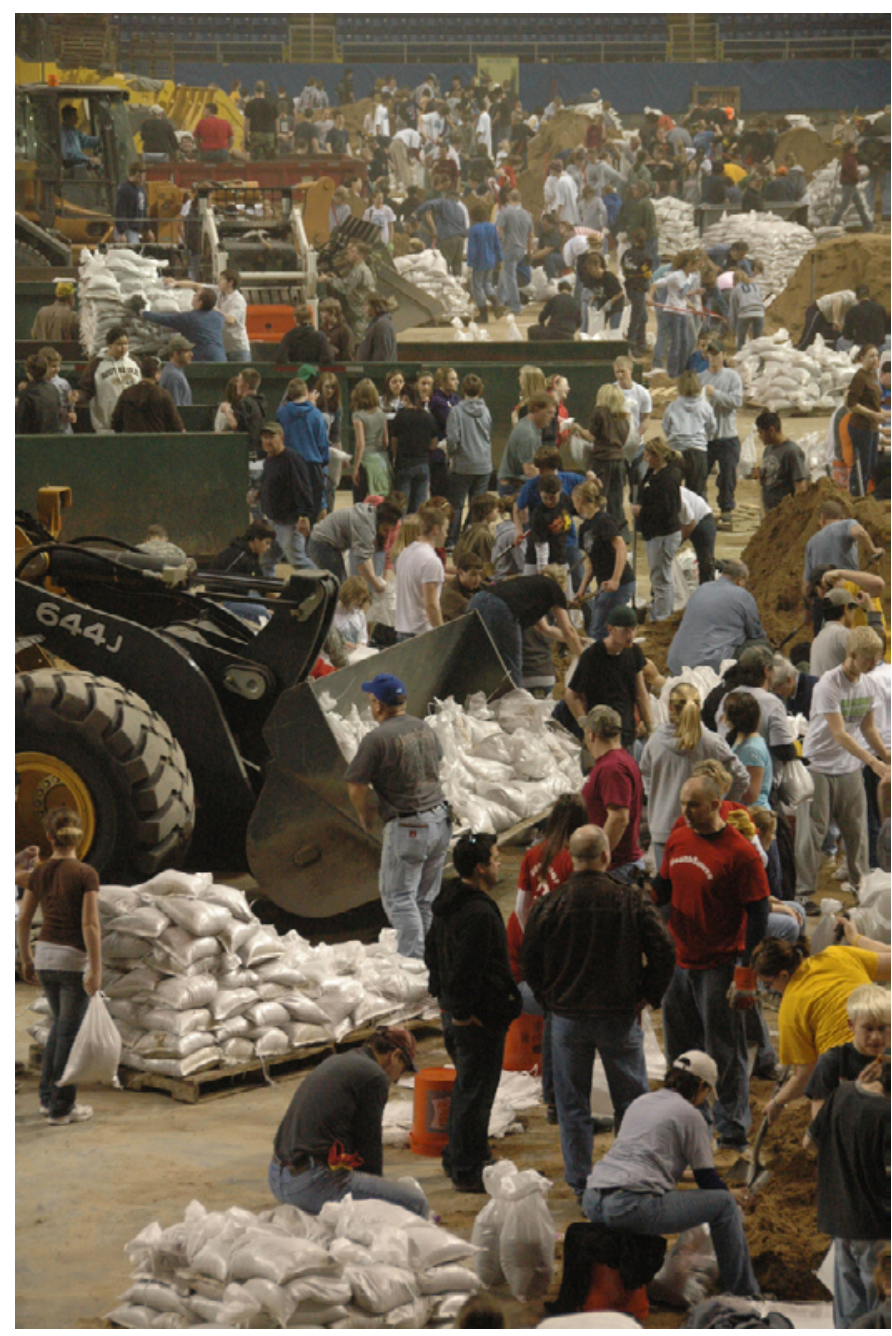

Members of the North Dakota National Guard and civilian floodfighting volunteers fill sandbags at the Fargodome in Fargo, North Dakota, March 24, 2009. Photograph by David Lipp, Federal Emergency Management Agency.

\section{Subbasins of Other Tributaries to the Red River of the North}

The tributaries on the west side of the Red River in North Dakota (fig. 5) begin in the Northern Glaciated Plains ecoregion (fig. 3). The valleys for these tributaries are generally narrow and steep-sided near the headwaters with flatter slopes the closer the tributaries get to the Red River. Because of the flatness of the basin, drainage basins for the North Dakota tributaries are not always well-defined. At times of high stage, flows from these tributaries often merge together creating large areas of water across the landscape. Once a substantial amount of water covers these areas it may be some time before the water completely recedes from, evaporates off, or infiltrates the landscape. Some of the larger tributaries on the west side of the Red River are the Wild Rice, Sheyenne, Rush, Elm, Goose, Turtle, Forest, Park, and Pembina Rivers (fig. 1).
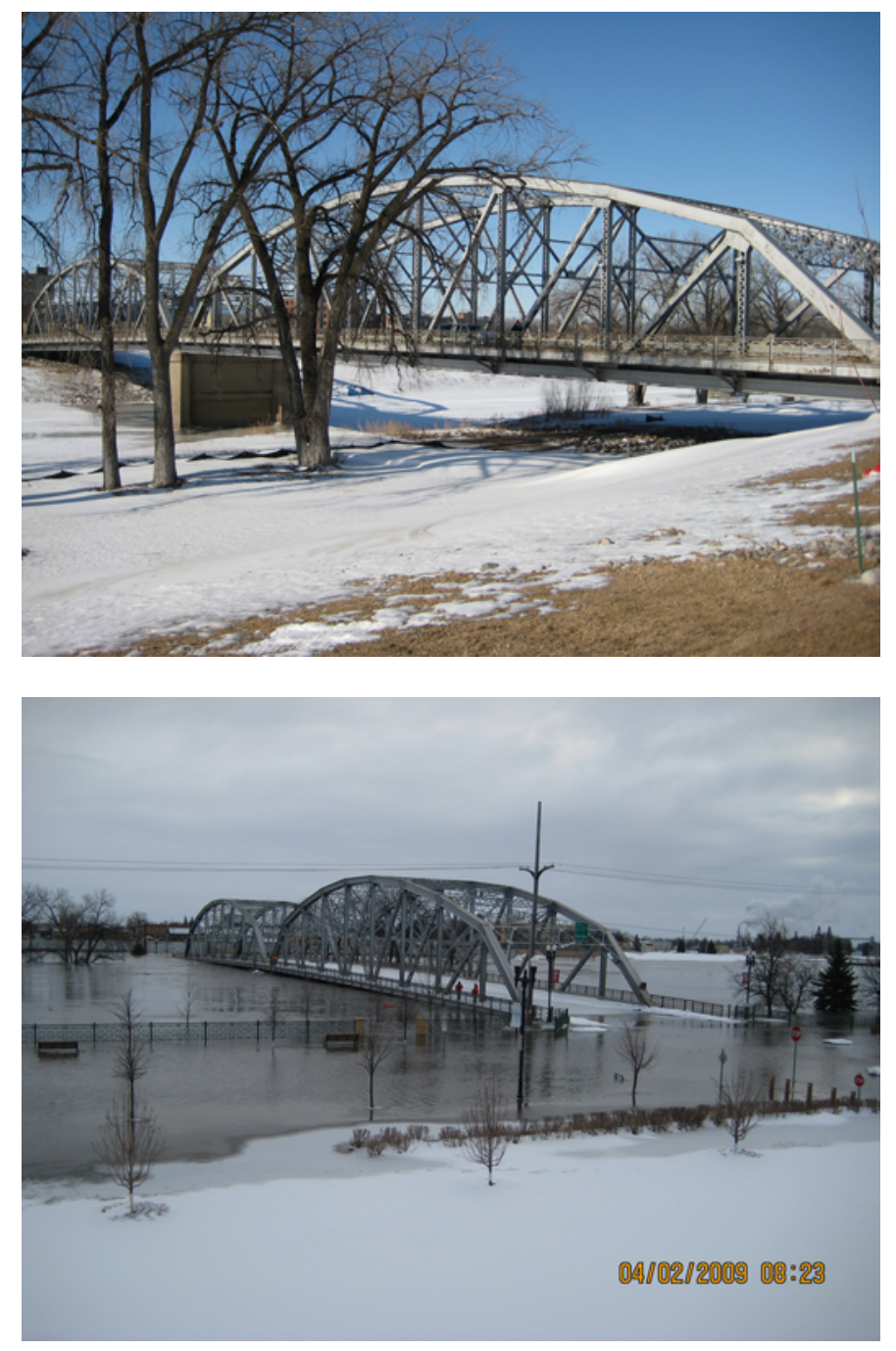

DeMers Bridge across the Red River between Grand Forks, North Dakota and East Grand Forks, Minnesota. Pre-flood photograph taken March 14, 2009. Flood photograph taken April 2, 2009 by U.S. Geological Survey personnel measuring discharge. (fig. 5, site 36). Photographs by U.S. Geological Survey personnel.

Tributaries on the east side of the Red River in Minnesota begin in the Lake Agassiz Plains ecoregion. Like their western counterparts, the tributaries on the east side of the Red River in Minnesota have valleys that are more defined near their headwaters and are flatter and less-defined near the Red River. The east side of the basin faces similar flooding problems as the west side of the basin. Some of the larger tributaries on the east side of the Red River are the Otter Tail, Buffalo, Wild Rice, Marsh, Sand Hill, Red Lake, Snake, Middle, and Roseau Rivers (fig. 1).

At the Otter Tail River near Elizabeth, Minn., (site 1, fig. 5, and table 6) the peak stage was $9.66 \mathrm{ft}$ on May 1, 2009 and the peak discharge was $1,330 \mathrm{ft}^{3} / \mathrm{s}$, which was $150 \mathrm{ft}^{3} / \mathrm{s}$ more than the 2001 peak of record discharge $1,170 \mathrm{ft}^{3} / \mathrm{s}$. The 
recurrence interval range for the 2009 peak discharge was 25-50 years.

On March 25, 2009, the peak stage of the Wild Rice River near Abercrombie, N. Dak., (site 12, fig. 5, table 6), was $27.78 \mathrm{ft}$. The peak discharge was $14,100 \mathrm{ft}^{3} / \mathrm{s}$, which was $4,560 \mathrm{ft}^{3} / \mathrm{s}$ greater than the 1969 peak of record discharge of $9,540 \mathrm{ft}^{3} / \mathrm{s}$ and is a new peak of record. The recurrence interval range for the 2009 peak discharge was 25-50 years.

At the Clearwater River at Red Lake Falls, Minn., (site 33, fig. 5, table 6) the peak stage was $13.75 \mathrm{ft}$ on March 25, 2009, and the peak discharge was 12,400 ft $3 / \mathrm{s}$, which was $2,100 \mathrm{ft}^{3} / \mathrm{s}$ more than the 1979 discharge of $10,300 \mathrm{ft}^{3} / \mathrm{s}$. The recurrence interval for the 2009 peak discharge was 50 years.

On April 20, 2009, the peak stage of the Pembina River near Neche, N. Dak., (site 49, fig. 5, table 6), was $21.61 \mathrm{ft}$. The peak discharge was $16,900 \mathrm{ft}^{3} / \mathrm{s}$, which was $1,800 \mathrm{ft}^{3} / \mathrm{s}$ more than the 1997 peak of record discharge of $15,100 \mathrm{ft}^{3} / \mathrm{s}$. The recurrence interval range for the 2009 peak discharge was $50-100$ years.

\section{Sheyenne River Subbasin}

Like other tributaries to the Red River, the Sheyenne River has seen its share of major flooding in past years. In 2009 , there were eight peak of record stages and eight peak of record discharges recorded at Sheyenne River subbasin streamgages.

The Sheyenne River is the longest river in North Dakota at 506 miles (fig. 7). The river runs through part of North Dakota's Northern Glaciated Plains ecoregion (fig. 3). The Sheyenne River empties into the Red River east of Harwood, N. Dak. (about 10 miles downstream from Fargo). The Sheyenne River subbasin encompasses $10,500 \mathrm{mi}^{2}$. Flow along the lower Sheyenne River is regulated by Baldhill Dam located about 12 miles upstream from Valley City, N. Dak. (population 6,850) (North Dakota Data Census Center, City Census Data, accessed January 2010 at $h t t p: / / w w w . n d s u . n o d a k . e d u /$ sdc/data/census.htm) (fig. 7).

The U.S. Army Corps of Engineers began to release water from Baldhill Dam in the fall and winter of 2008-09 to make storage available for incoming spring flows. Despite the precautions taken, the U.S. Army Corps of Engineers needed to release nearly $6,600 \mathrm{ft}^{3} / \mathrm{s}$ in the spring of 2009 to manage the inflows from upstream (U.S. Army Corps of Engineers, 2009a). Large discharges from Lake Ashtabula helped to create peak of record stages and discharges at streamgages downstream from Baldhill Dam. Many residents of Valley City were asked to evacuate the city as flood waters strained public utilities and closed many low-lying roads in the area (Fargo-Moorhead Forum, April 15, 2009, accessed January 2011 at $h t t p: / / w w w . i n f o r u m . c o m / e v e n t / a r t i c l e / i d / 237354 /)$.

On April 17, 2009, the peak discharge of the Sheyenne River at Valley City, N. Dak., (site 8, fig. 7, table 7), was $7,940 \mathrm{ft}^{3} / \mathrm{s}$. The recurrence interval range for the 2009 peak discharge was 100-200 years. The peak stage was $20.69 \mathrm{ft}$, which occurred on April 13, 2009. The stage was $2.68 \mathrm{ft}$ more than the 1997 peak stage of $18.01 \mathrm{ft}$. The 2009 peak stage was the highest stage recorded for this streamgage.

Downstream from Valley City on April 16, 2009, the peak discharge for the Sheyenne River at Lisbon, N. Dak. (site 9, fig. 7, table 7) was $9,250 \mathrm{ft}^{3} / \mathrm{s}$. The recurrence interval range for the 2009 peak discharge was $50-100$ years. The peak stage was $22.86 \mathrm{ft}$, which occurred on April 16, 2009. The stage was $3.57 \mathrm{ft}$ more than the 1997 peak stage of $19.29 \mathrm{ft}$. The 2009 peak discharge and stage were the highest discharge and stage recorded for this streamgage.

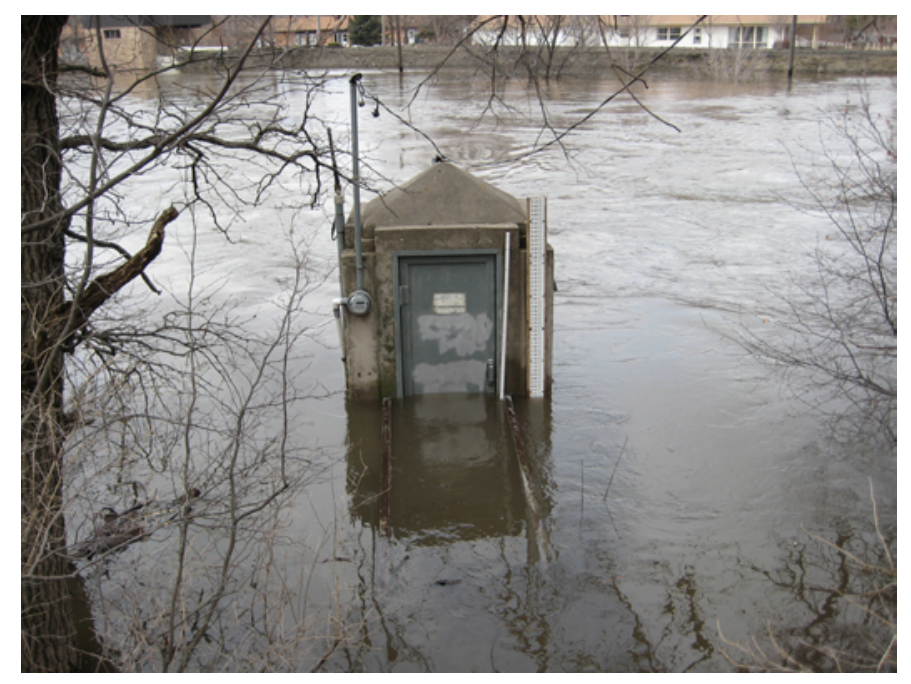

Sheyenne River at Valley City, North Dakota streamgage on April 13, 2009, at a stage of $20.35 \mathrm{ft}$ (fig. 7, site 8). Photograph by Kathleen Rowland, USGS.

\section{Devils Lake Subbasin}

The Devils Lake subbasin is a 3,810-square-mile closed subbasin within the Red River Basin in North Dakota. At an elevation of about 1,446.5 ft above NGVD 29, Devils Lake begins to spill over into nearby Stump Lake (fig. 8) The combined lakes discharge no water until the lake level reaches 1,458 ft above NGVD 29, the lowest natural outlet elevation (North Dakota State Water Commission, Devils Lake fact sheet, 2011 accessed March 2011 at http://www. swc.state.nd.us/4dlink9/4dcgi/GetContentPDF/PB-206/ DLFactSheetR.pdf). When water reaches this level, it spills into the Sheyenne River through Tolna Coulee (fig. 5). Within the past 10,000 years, Devils Lake has fluctuated from being nearly dry to spilling over its natural outlet. A recent study by the North Dakota Geological Survey indicated that there have been at least seven confirmed flood events, possibly more, at Tolna Coulee in the past 10,000 years (Murphy and others, 2002). 
POSSIBLE SOLUTIONS To begin a realistic progras of rlood danage reduction, valley Cit, nust know the elevations that future floods can be expocted to reach an areas which nay be flooded.

With the exception of the Apri1 1948 and Apri1 1969 floods, past flood have not cavsed extenaive darage in Valley city because of the linited developrent in the flood plain. A. time passes, hevever, and residen. tial and industrial developent in. creases, there $\mathrm{x}$ t1 greater denand for building sites in the city. Unless properly regulated, some of these sites could be on land vulnerable to serlous flood danage. A further denger is that new devel. opeents in the flood plain, if unregulated, coold be so constructed as to reatriet the flow of water and thus increase flood belghts and dae. age epatrens.

Flood data and reasonable rezula. tions can be used to gulde and con- trel developents in fleod hazard rrol developarats in theod hazard thood and to prevent an increano in

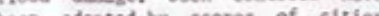
been acopted oy scores of cities and have becone accopted as a pract cical approach to The provention of

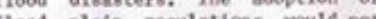
hood plais regulations wourd not prevent the sis or tho aren for ged by flooding.

Corrective measures may tnclude flood proofing to make existing and proposed struetures less wulnerable. hats involves permanently elosing lower openings, using thap valves oa sewer openings, installing removable bulkhoads over entrances.

Thts folder has been prepared froe data in the Corps of Engineers reort, "Flood Plain Intornation, Sheyenne Biver in Valley City, North Dakota." Copies of that report and pakto. coples of that report and chifleider are Mayor of Yalley City

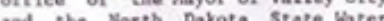
Cominision.

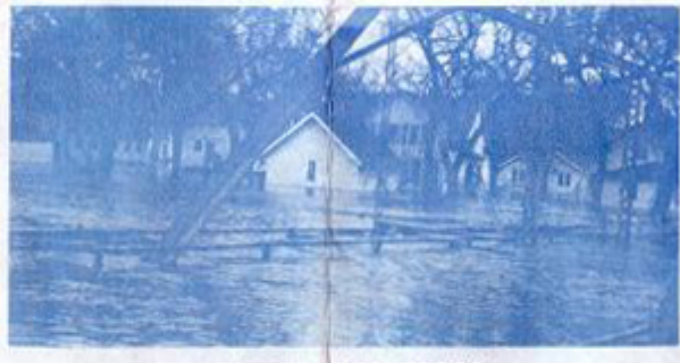

APRIL 1948 FLOOD

\section{FLOODS IN VALLEY CITY, NORTH DAKOTA}

\section{- How to Avoid Damage}

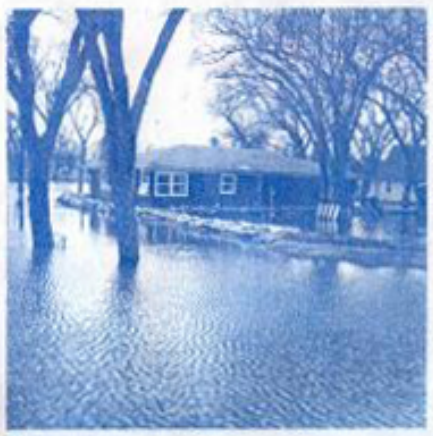

City Coune 11 valley City, North Dakot ctober 1970

\section{FLOODS IN \\ VALLEY CITY}

Since 1882 the Sheyense River at Valtey City has left its banks 10 times. During these past floods damage has generally been linited to roads, bridges, agricultural land and lover residential areas adjacent to the river.

A large flood now could serlously town of Valley City. Hio only would basinesses, hooss and transportation facilities in the flood plain bear the brunt of the misfortune, but also the econony and generar velfare of the entire camminity would be affected.

This reeurring damage need not bappen. Data to guide anfe comuntty developrent and methods for reducins future flood damage are avallable. The city Council of Valley city feels that the citizens should be aware that large floods may be expected and that damage can be greatiy reduced only if precautionary measurea are

\section{PAST FLOODS}

The highest known flood on the shey. enne kiver in the vicinity of Valley City was that of Apr11, 1969. The flood of Apri1, 1948, was only 0.12 teet lover.

Floods on the Sheyenne River are nost frequent in the late vinter and early oping in the late vinter and early upring due to fee jans and abFlasb fanoff from nelting anov. Hast inods can aloo occur at other terstor the year from intence derstorns.

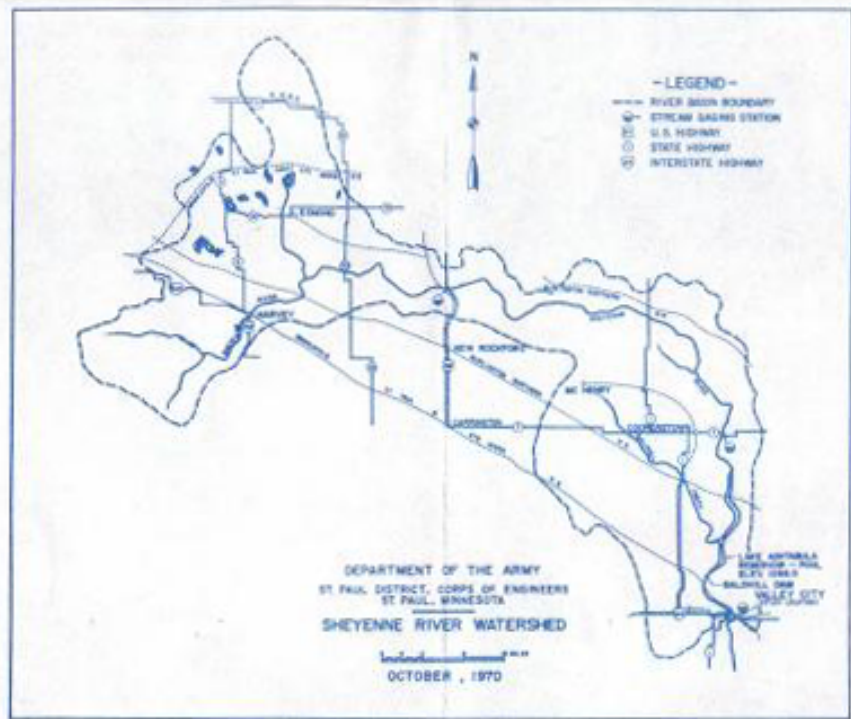

\section{FUTURE FLOODS}

A study of past floode and storms In the ares surrounding valley City Indicates that future floods cosid be significantiy higher than past floods.

An Intermediate Regional Flood was fetermined fron consideration of known floods that have oceurred on the shiejenne River. The Intermed- occurrence of once every 100 years and would be about 5.0 feet hirgh The Standard Project Flood represebta reasonable upper 1 inits of expected flooding, the stage of which would be approxinately 11.0 feet higher than the 1969 flood. The increased flooded area woutd be significant as shown on the nap Inside this orochure, and with pieturea shoving heights thet future floods could reach at selected locations.

1970 Flood pamphlet for Valley City, North Dakota distributed by the Valley City Council during previous flooding in the 1970s indicating the city's history with floods. 


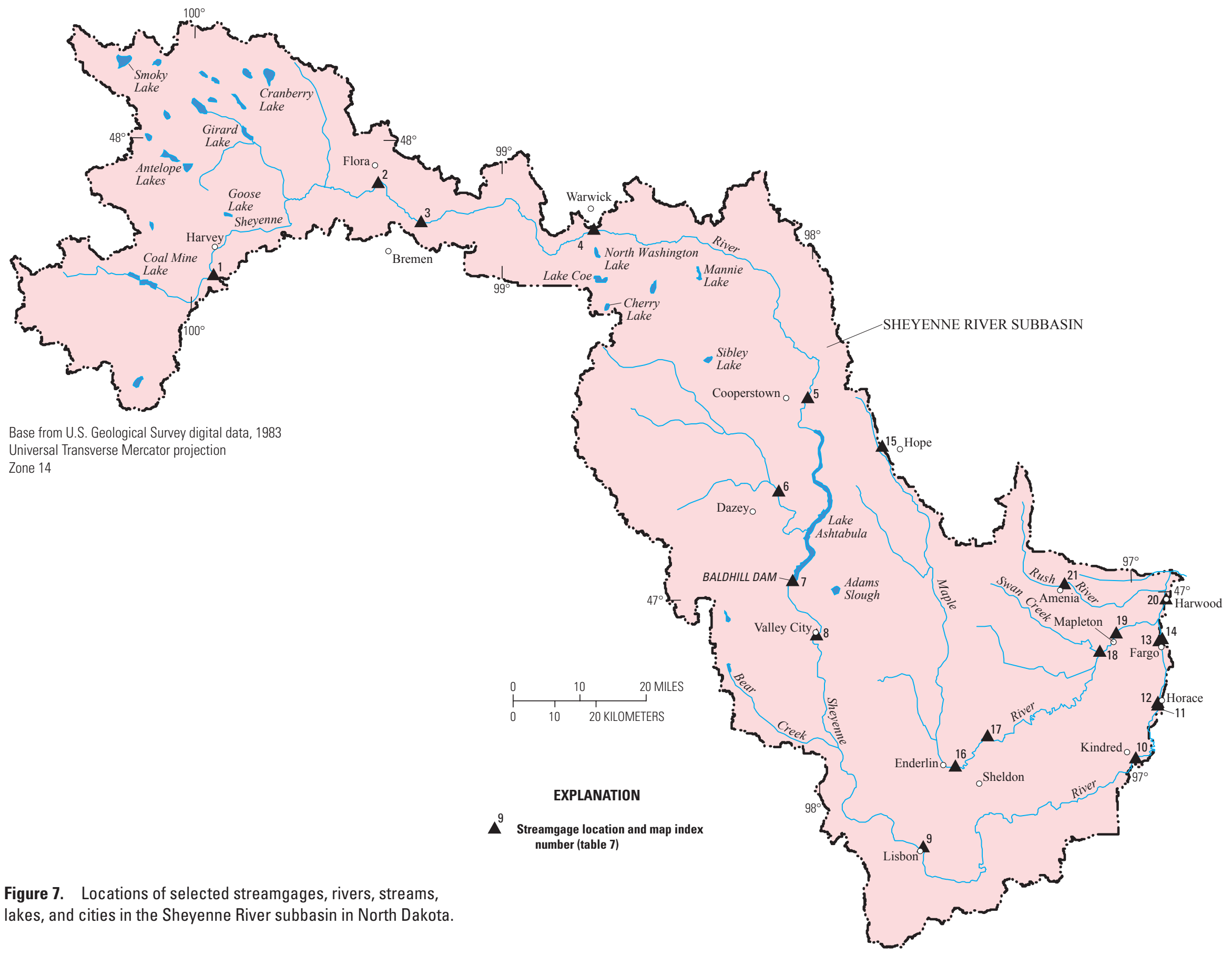

Figure 7. Locations of selected streamgages, rivers, streams, lakes, and cities in the Sheyenne River subbasin in North Dakota. 
Table 7. Historical and 2009 peak of record stages and discharges for the Sheyenne River subbasin in North Dakota.

[Data and footnotes in this table as well as additional station information can be found by searching on the station (site) number on the table in the U.S. Geological Survey's Water-resources data for the United States, Water Year 2009 accessed on January 2011 at $h t t p: / / w d r$ water.usgs.gov/wy2009/search.jsp. $\mathrm{mi}^{2}$, square miles; ft, feet; fts, cubic feet per second; red print, peak of record; na, not available; reg., regulated]

\begin{tabular}{|c|c|c|c|c|c|c|c|c|c|c|c|c|}
\hline \multirow[b]{2}{*}{$\begin{array}{l}\text { Site } \\
\text { (fig. 7) }\end{array}$} & \multirow[b]{2}{*}{ Station name and number } & \multirow[b]{2}{*}{$\begin{array}{c}\text { Drainage } \\
\text { area } \\
\left(\mathbf{m i}^{2}\right)\end{array}$} & \multicolumn{5}{|c|}{ Maximum peaks previously known from period of record } & \multicolumn{5}{|c|}{ Maximum peaks from March to September 2009} \\
\hline & & & $\begin{array}{c}\text { Period of } \\
\text { known } \\
\text { peaks }\end{array}$ & $\begin{array}{c}\text { Date of } \\
\text { peak stage }\end{array}$ & $\begin{array}{l}\text { Stage } \\
\text { (ft) }\end{array}$ & $\begin{array}{c}\text { Date of } \\
\text { peak discharge }\end{array}$ & $\begin{array}{l}\text { Discharge } \\
\left(\mathrm{ft}^{3} / \mathbf{s}\right)\end{array}$ & $\begin{array}{c}\text { Date of } \\
\text { peak stage }\end{array}$ & $\begin{array}{l}\text { Stage } \\
\text { (ft) }\end{array}$ & $\begin{array}{c}\text { Date of } \\
\text { peak discharge }\end{array}$ & $\begin{array}{l}\text { Discharge } \\
\left(\mathrm{ft}^{3} / \mathbf{s}\right)\end{array}$ & $\begin{array}{c}\text { Recurrence } \\
\text { interval } \\
\text { (years) }\end{array}$ \\
\hline 1 & $\begin{array}{l}\text { Sheyenne River above Harvey, } \\
\text { N. Dak. }(05054500)\end{array}$ & 424 & $1955-2008$ & $04 / 06 / 1997$ & ${ }^{\mathrm{a}} 10.76$ & $04 / 20 / 1979$ & 1,000 & $04 / 15 / 2009$ & 10.46 & $04 / 15 / 2009$ & 2,100 & $100-200$ \\
\hline 2 & $\begin{array}{l}\text { Sheyenne River above Devils Lake } \\
\text { State Outlet near Flora, N. Dak. } \\
(05055300)\end{array}$ & 1,661 & 2004-2008 & 07/03/2005 & 18.96 & 07/03/2005 & 906 & $04 / 14 / 2009$ & 23.36 & $04 / 14 / 2009$ & 3,550 & na \\
\hline 3 & $\begin{array}{l}\text { Sheyenne River below Devils Lake } \\
\text { State Outlet near Bremen, N. Dak. } \\
(05055400)\end{array}$ & 1,716 & $2005-2008$ & 07/03/2005 & 24.45 & 07/03/2005 & 977 & $04 / 14 / 2009$ & 27.68 & $04 / 14 / 2009$ & 3,980 & na \\
\hline 4 & $\begin{array}{l}\text { Sheyenne River near Warwick, } \\
\text { N. Dak. (05056000) }\end{array}$ & 2,070 & 1949-2008 & 04/21/1997 & 8.08 & $04 / 14 / 1969$ & 4,660 & $04 / 16 / 2009$ & 8.43 & $04 / 16 / 2009$ & 4,930 & $25-50$ \\
\hline 5 & $\begin{array}{l}\text { Sheyenne River near Cooperstown, } \\
\text { N. Dak. }(05057000)\end{array}$ & 6,470 & 1944-2008 & 04/18/1996 & 19.13 & $04 / 17 / 1950$ & 7,830 & $04 / 17 / 2009$ & 18.62 & 04/17/2009 & 6,280 & $10-25$ \\
\hline 6 & $\begin{array}{l}\text { Baldhill Creek near Dazey, N. Dak. } \\
\quad(05057200)\end{array}$ & 691 & $\begin{array}{c}1950 \\
1956-2008\end{array}$ & 04/19/1979 & b 17.78 & 04/19/1979 & a9,000 & $03 / 24 / 2009$ & ${ }^{\mathrm{a}} 11.94$ & $04 / 14 / 2009$ & $c 3,470$ & $10-25$ \\
\hline 7 & $\begin{array}{l}\text { Sheyenne River below Baldhill Dam, } \\
\text { N. Dak. }(05058000)\end{array}$ & 7,470 & 1949-2008 & 04/20/1996 & 36.46 & 04/20/1996 & 5,460 & $04 / 17 / 2009$ & 38.35 & $04 / 17 / 2009$ & ${ }^{\mathrm{d}} 6,200$ & 25-50 (reg.) \\
\hline 8 & $\begin{array}{l}\text { Sheyenne River at Valley City, } \\
\text { N. Dak. }(05058500)\end{array}$ & 7,810 & $\begin{array}{c}18821897 \\
1919 \\
1938-1975 \\
1979-2008\end{array}$ & $04 / 1882$ & 20.00 & 04/21/1996 & 5,250 & $04 / 13 / 2009$ & a20.69 & $04 / 17 / 2009$ & $\mathrm{~d}, \mathrm{e} 7,940$ & $\begin{array}{c}100-200 \\
\text { (reg.) }\end{array}$ \\
\hline 9 & $\begin{array}{l}\text { Sheyenne River at Lisbon, N. Dak. } \\
\quad(05058700)\end{array}$ & 8,190 & $\begin{array}{c}1950 \\
1956-2008\end{array}$ & 04/05/1997 & a 19.29 & $04 / 23 / 1997$ & 5,670 & $04 / 16 / 2009$ & 22.86 & $04 / 16 / 2009$ & d9,250 & 50-100 (reg.) \\
\hline 10 & $\begin{array}{l}\text { Sheyenne River near Kindred, } \\
\text { N. Dak. (05059000) }\end{array}$ & 8,800 & $\begin{array}{c}1947 \\
1949-2008\end{array}$ & 04/08/1997 & a22.33 & 04/27/1997 & 5,970 & $03 / 31 / 2009$ & a21.55 & 04/14/2009 & $\mathrm{d}, \mathrm{f} 5,940$ & 25-50 (reg.) \\
\hline 11 & $\begin{array}{l}\text { Sheyenne River above Sheyenne } \\
\text { River Diversion near Horace, } \\
\text { N. Dak. (05059300) }\end{array}$ & 8,840 & $1992-2008$ & 03/25/1999 & a26.66 & 05/08/1997 & $\mathrm{d} 5,210$ & $04 / 09 / 2009$ & $\mathrm{~g}_{25.59}$ & $04 / 14 / 2009$ & $\mathrm{~d}, \mathrm{~h} 4,710$ & 5-10 (reg.) \\
\hline 12 & $\begin{array}{r}\text { Sheyenne River Diversion near } \\
\text { Horace, N. Dak. (05059310) }\end{array}$ & na & 1992-2008 & 03/25/1999 & $\mathrm{a}, \mathrm{b} 26.66$ & 04/10/2001 & 2,760 & $04 / 09 / 2009$ & i 25.00 & 04/09/2009 & $\mathrm{d} 2,750$ & na \\
\hline 13 & $\begin{array}{l}\text { Sheyenne River Diversion at West } \\
\text { Fargo, N. Dak. (05059480) }\end{array}$ & na & 1992-2008 & 04/09/1997 & a22.90 & 04/19/1997 & j4,810 & $03 / 27 / 2009$ & $\mathrm{k}_{22} 2.88$ & $04 / 12 / 2009$ & $\mathrm{~d}, 14,760$ & na \\
\hline 14 & $\begin{array}{l}\text { Sheyenne River at West Fargo, } \\
\text { N. Dak. (05059500) }\end{array}$ & 8,870 & $\begin{array}{l}1902-1907 \\
1919 \\
1929-2008\end{array}$ & 04/09/1997 & a22.90 & 04/19/1997 & 4,810 & $03 / 27 / 2009$ & ${ }^{k} 22.88$ & $04 / 12 / 2009$ & $\mathrm{~d}, \mathrm{l} 4,760$ & na \\
\hline 15 & $\begin{array}{l}\text { Maple River near Hope, N. Dak. } \\
\quad(05059600)\end{array}$ & 20.2 & 1964-2008 & 03/31/1997 & a 8.83 & $03 / 28 / 2004$ & ${ }^{\mathrm{m}} 1,000$ & $03 / 22 / 2009$ & a 7.22 & $04 / 12 / 2009$ & n449 & $5-10$ \\
\hline 16 & $\begin{array}{l}\text { Maple River near Enderlin, N. Dak. } \\
\quad(05059700)\end{array}$ & 843 & 1956-2008 & 06/30/1975 & 15.41 & $06 / 30 / 1975$ & 7,610 & $03 / 24 / 2009$ & 14.14 & 03/24/2009 & 7,490 & $25-50$ \\
\hline
\end{tabular}


[Data and footnotes in this table as well as additional station information can be found by searching on the station (site) number on the table in the U.S. Geological Survey's Water-resources data for the United States, Water Year 2009 accessed on January 2011 at http://wdr.water.usgs.gov/wy2009/search.jsp. $\mathrm{mi}^{2}$, square miles; ft, feet; fts, cubic feet per second; red print, peak of record; na, not available; reg., regulated]

\begin{tabular}{|c|c|c|c|c|c|c|c|c|c|c|c|c|}
\hline \multirow[b]{2}{*}{$\begin{array}{l}\text { Site } \\
\text { (fig. 7) }\end{array}$} & \multirow[b]{2}{*}{ Station name and number } & \multirow[b]{2}{*}{$\begin{array}{c}\text { Drainage } \\
\text { area } \\
\left(\mathrm{mi}^{2}\right)\end{array}$} & \multicolumn{5}{|c|}{ Maximum peaks previously known from period of record } & \multicolumn{5}{|c|}{ Maximum peaks from March to September 2009} \\
\hline & & & $\begin{array}{l}\text { Period of } \\
\text { known } \\
\text { peaks }\end{array}$ & $\begin{array}{c}\text { Date of } \\
\text { peak stage }\end{array}$ & $\begin{array}{l}\text { Stage } \\
\text { (ft) }\end{array}$ & $\begin{array}{c}\text { Date of } \\
\text { peak discharge }\end{array}$ & $\begin{array}{l}\text { Discharge } \\
\left(\mathrm{ftt}^{3} / \mathbf{s}\right)\end{array}$ & $\begin{array}{c}\text { Date of } \\
\text { peak stage }\end{array}$ & $\begin{array}{l}\text { Stage } \\
\text { (ft) }\end{array}$ & $\begin{array}{c}\text { Date of } \\
\text { peak discharge }\end{array}$ & $\begin{array}{l}\text { Discharge } \\
\left(f^{3} / s\right)\end{array}$ & $\begin{array}{c}\text { Recurrence } \\
\text { interval } \\
\text { (years) }\end{array}$ \\
\hline 17 & $\begin{array}{l}\text { Maple River above Maple River Dam } \\
\text { near Sheldon, N. Dak. (05059715) }\end{array}$ & na & 2007 & $06 / 27 / 2007$ & $1,023.55$ & $06 / 27 / 2007$ & 888 & $04 / 15 / 2009$ & $1,052.93$ & $04 / 15 / 2009$ & $\mathrm{~d} 5,010$ & na \\
\hline 18 & $\begin{array}{l}\text { Maple River near Mapleton, N. Dak. } \\
(05060000)\end{array}$ & 1,450 & $\begin{array}{l}1958-1975 \\
2001-2008\end{array}$ & $04 / 01 / 2006$ & 23.43 & $07 / 02 / 1975$ & 11,600 & $03 / 25 / 2009$ & a 23.30 & $03 / 25 / 2009$ & ${ }^{\mathrm{d}} 6,470$ & na \\
\hline 19 & $\begin{array}{l}\text { Maple River below Mapleton, } \\
\text { N. Dak. }(05060100)\end{array}$ & 1,480 & $\begin{array}{l}1944-1958 \\
1995-2008\end{array}$ & 04/08/1997 & 24.96 & $04 / 01 / 2006$ & 7,240 & 03/27/2009 & a24.77 & $03 / 26 / 2009$ & $\mathrm{~d}, \mathrm{p} 6,140$ & na \\
\hline 20 & $\begin{array}{l}\text { Sheyenne River at Harwood, N. Dak. } \\
(05060400)\end{array}$ & na & $1995-2008$ & 04/16/1997 & 92.02 & 04/16/1997 & 11,000 & 03/29/2009 & a91.72 & 03/29/2009 & 10,000 & 5-10 (reg.) \\
\hline 21 & $\begin{array}{l}\text { Rush River at Amenia, N. Dak. } \\
(05060500)\end{array}$ & 116 & 1946-2008 & 03/23/1966 & ${ }^{\mathrm{a}} 12.15$ & 04/19/1979 & 93,490 & $03 / 24 / 2009$ & ${ }^{\mathrm{a}} 11.37$ & $03 / 24 / 2009$ & 2,000 & $10-25$ \\
\hline
\end{tabular}

${ }^{a}$ Backwater from ice, debris aquatic vegetation, or other water resource.

${ }^{\mathrm{b}}$ From high-water mark.

${ }^{\mathrm{c}}$ Gage height, 11.77 feet.

${ }^{\mathrm{d}}$ Affected by regulation period.

${ }^{\mathrm{e}}$ Gage height, 20.59 feet.

${ }^{\mathrm{f}}$ Gage height, 21.10 feet.

${ }^{g}$ Recorded, backwater from ice, may have been higher during period of no stage record, April 9-10.

${ }^{\mathrm{h}}$ Gage height, 25.16 feet.

iEstimated peak recorded stage at station 05059300 was 25.59 feet. Based on site visit on March 30, stage at diversion channel was about 0.60 feet lower.

Unknown amount of flow entered diversion through flapper gates and overtopping of diversion levee during April and May.

${ }^{k}$ Recorded, backwater from ice, may have been higher during period of no stage record, March 27-28.

'Gage height, 22.54 feet.

mage height, 6.98 feet.

${ }^{n}$ Gage height, 6.21 feet.

'Observed backwater from ice, may have been higher during period of no gage-height record, April 6-9, 1997.

${ }^{\mathrm{p} G a g e}$ height, 24.70 feet.

${ }^{\mathrm{q}} \mathrm{Gage}$ height, 10.37 feet. 


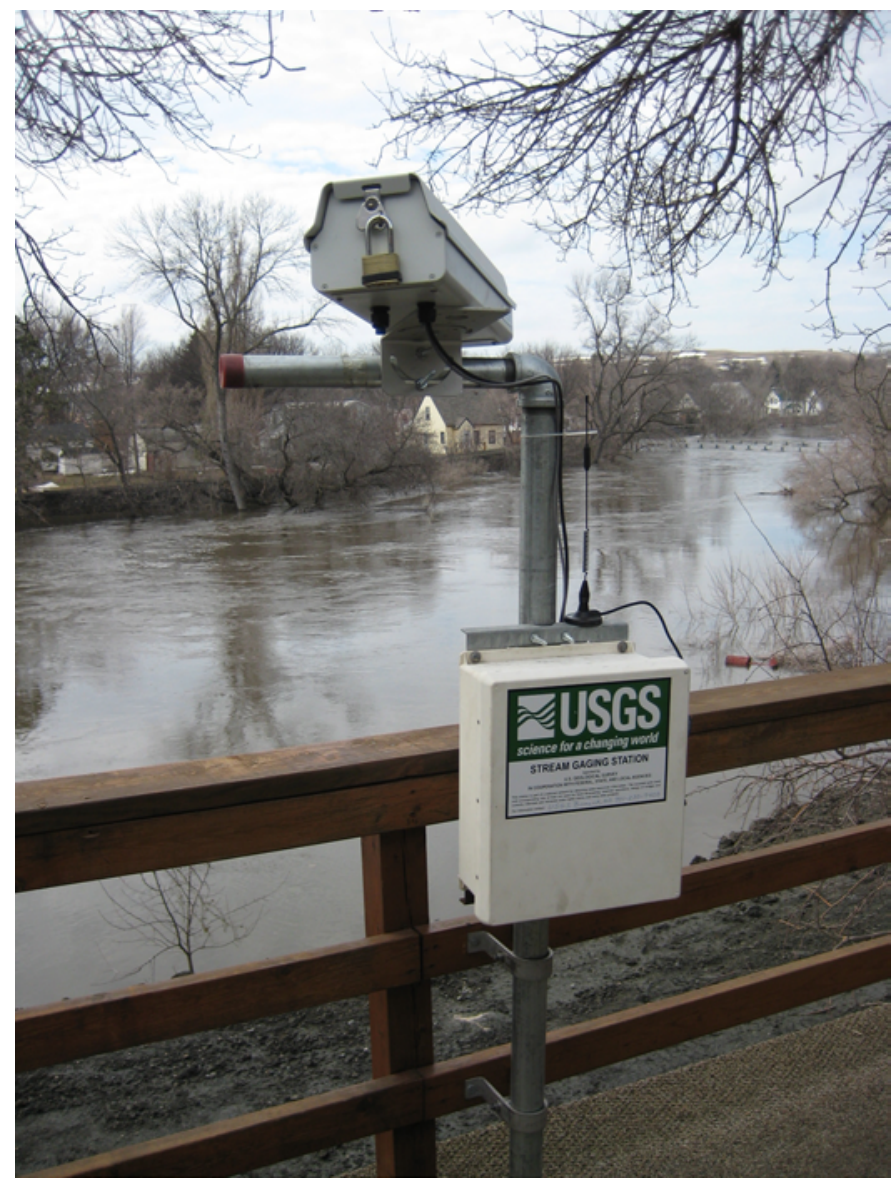

U.S. Geological Survey camera temporarily mounted on the deck of a home in Valley City, North Dakota, showed the Sheyenne River during flooding, April 13, 2009. During the 2009 spring floods the photographs taken by this camera were accessed by the public on the U.S. Geological Survey North Dakota Water Science Center's website, accessed January 2011 at http://nd.water.usgs.gov/floodinfo/ floodinfo09.html.

Since 1993, Devils Lake has risen about $28 \mathrm{ft}$ in response to above-normal precipitation in the basin and below-normal evaporation from the lake surface. In June 2009, the lake level was 1,450.7 ft (NGVD 29), $28.1 \mathrm{ft}$ higher than the level recorded in February 1993. The rising water inundated homes, businesses, and agricultural lands and caused roads to be closed permanently. Some small towns in the area have been abandoned because of the rising water levels. The damages and cost of mitigation efforts caused by the rising water have exceeded $\$ 852$ million and sparked controversy on mitigating the rising water (Federal Interagency Devils Lake Working Group, 2010). To help mitigate the flooding problem a series of levees extending for about 8 miles around the city of Devils Lake is being raised by the U.S. Army Corps of
Engineers (Bismarck Tribune, accessed January 2011 at $h t t p: / /$ www.bismarcktribune.com/news/state-and-regional/article f91610e6-e024-11de-a985-001cc4c002e0.html).

In the Devils Lake subbasin, eight peak of record stages and two peak of record discharges were recorded at several locations in the basin. At Edmore Coulee near Edmore, N. Dak., (site 3, fig. 8, table 8), the peak stage was $88.01 \mathrm{ft}$ on March 31, 2009. The peak stage exceeded the peak of record set in 1997 by $0.06 \mathrm{ft}$. The peak discharge was $1,160 \mathrm{ft}^{3} / \mathrm{s}$ on April 16, 2009. The recurrence interval range for the peak discharge was 5-10 years.

For Starkweather Coulee near Webster, N. Dak., (site 6, fig. 8, table 8), the peak discharge was $978 \mathrm{ft}^{3} / \mathrm{s}$ and the stage was $8.58 \mathrm{ft}$. on April 17, 2009. The peak discharge was $70 \mathrm{ft}^{3} / \mathrm{s}$ greater than 2004 peak discharge of $908 \mathrm{ft}^{3} / \mathrm{s}$. The recurrence interval range for the peak discharge was 10-25 years.

On April 16, 2009, the stage of the Little Coulee near Leeds, N. Dak. (site 9, fig. 8, table 8), was $68.41 \mathrm{ft}$. The peak discharge for that stage was $395 \mathrm{ft}^{3} / \mathrm{s}$, which was $126 \mathrm{ft}^{3} / \mathrm{s}$ more than the peak of record discharge of $269 \mathrm{ft}^{3} / \mathrm{s}$ occurring 1999. The recurrence interval range for the peak discharge was 10-25 years. The peak of record stage of $68.61 \mathrm{ft}$ occurred on April 19, 2009. No discharge was reported for this stage.

\section{Souris River Subbasin}

The Souris River (or Mouse River) is one of the larger tributaries to the Red River (fig. 1). It begins in Saskatchewan, Canada and flows south where it makes a 357-mile loop through North Dakota before returning to Canada where it joins the Red River in Manitoba. Because the Souris River is an international river, the International Joint Commission (IJC) established the International Souris River Board of Control to monitor compliance with the apportionment arrangements between the two countries (Gregg Wiche, U.S. Geological Survey, written commun., 2011). In North Dakota, the river basin is located in the Northern Glaciated Plains ecoregion and encompasses about $8,000 \mathrm{mi}^{2}$ (fig. 9). The basin is characterized by rolling terrain with areas of wetlands and potholes. Although ice jams occurred at several places on the Souris River in the spring of 2009 , none of the ice jams posed serious threats to the people or property in the area. Only one peak of record stage and one peak of record discharge were recorded in this basin in 2009. Both peaks of record occurred at the same USGS streamgage near Verendrye, N. Dak.

On April 15, 2009, the peak stage of the Souris River near Verendrye, N. Dak., (site 8, fig. 9, table 9), was $17.92 \mathrm{ft}$. The peak discharge was $10,900 \mathrm{ft}^{3} / \mathrm{s}$, which was $1,000 \mathrm{ft}^{3} / \mathrm{s}$ more than the 1976 peak discharge of $9,900 \mathrm{ft}^{3} / \mathrm{s}$. The recurrence interval range for the 2009 peak discharge was 100-200 years. The 2009 peak stage and discharge were new peaks of record for this streamgage. 


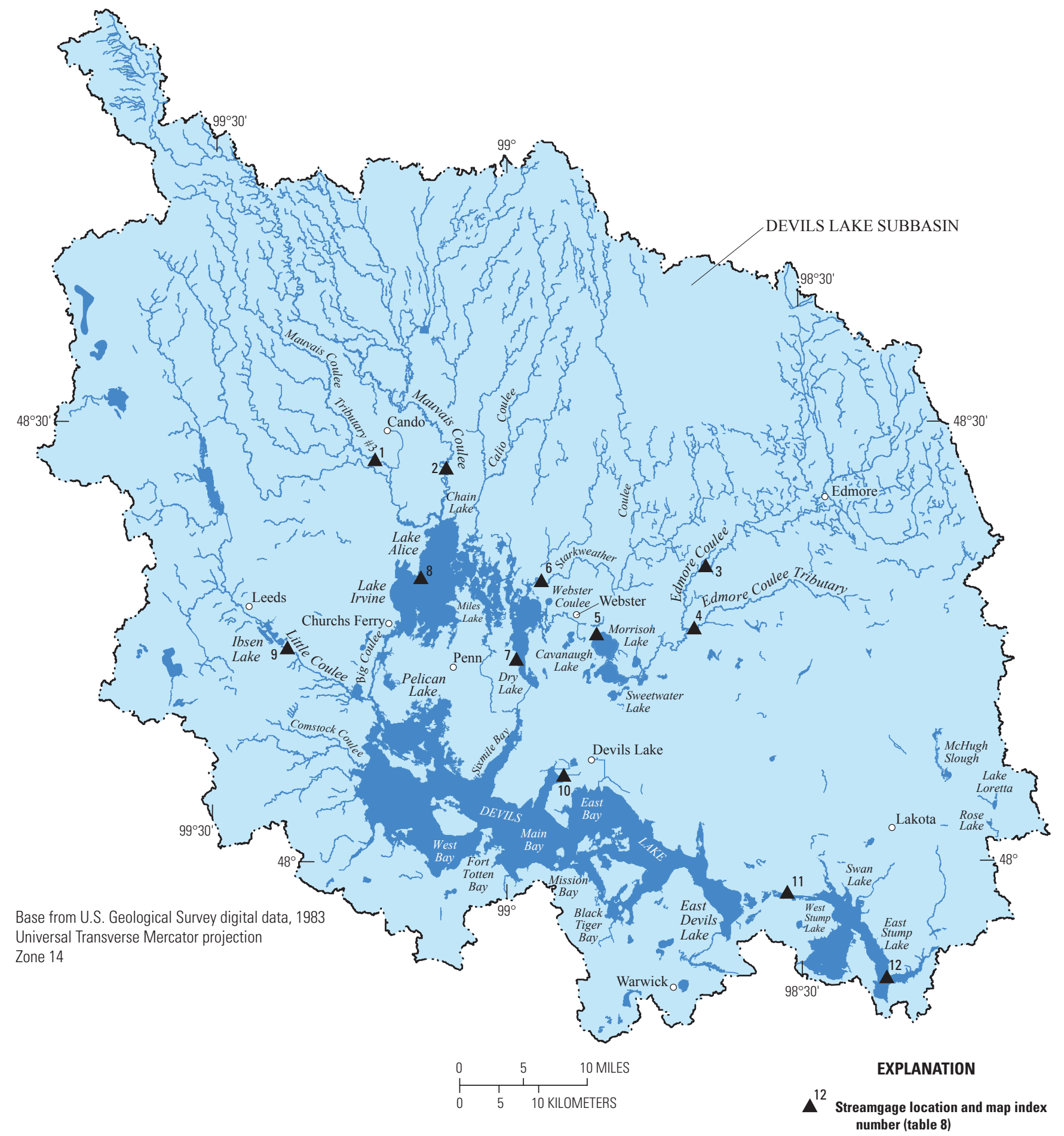

Figure 8. Locations of selected streamgages, rivers, lakes, streams, lakes, and cities in the Devils Lake subbasin in North Dakota. 
Table 8. Historical and 2009 peak of record stages and discharges for the Devils Lake subbasin in North Dakota.

[Data and footnotes in this table as well as additional station information can be found by searching on the station (site) number on the table in the U.S. Geological Survey's Water-resources data for the United States, Water Year 2009 accessed on January 2011 at http://wdr.water.usgs.gov/wy2009/search.jsp. $\mathrm{mi}^{2}$, square miles; ft, feet; fts, cubic feet per second; red print, peak of record; na, not available]

\begin{tabular}{|c|c|c|c|c|c|c|c|c|c|c|c|c|}
\hline \multirow[b]{2}{*}{$\begin{array}{c}\text { Site } \\
\text { (fig. 8) }\end{array}$} & \multirow[b]{2}{*}{ Station name and number } & \multirow[b]{2}{*}{$\begin{array}{c}\text { Drainage } \\
\text { area } \\
\left(\mathrm{mi}^{2}\right)\end{array}$} & \multicolumn{5}{|c|}{ Maximum peaks previously known from period of record } & \multicolumn{5}{|c|}{ Maximum peaks from March to September 2009} \\
\hline & & & $\begin{array}{c}\text { Period of } \\
\text { known } \\
\text { peaks }\end{array}$ & $\begin{array}{c}\text { Date of } \\
\text { peak stage }\end{array}$ & $\begin{array}{c}\text { Stage } \\
\text { (ft) }\end{array}$ & $\begin{array}{c}\text { Date of } \\
\text { peak discharge }\end{array}$ & $\begin{array}{c}\text { Discharge } \\
\left(\mathrm{ft}^{3} / \mathrm{s}\right)\end{array}$ & $\begin{array}{c}\text { Date of } \\
\text { peak stage }\end{array}$ & $\begin{array}{l}\text { Stage } \\
\text { (ft) }\end{array}$ & $\begin{array}{c}\text { Date of } \\
\text { peak discharge }\end{array}$ & $\begin{array}{l}\text { Discharge } \\
\left(\mathrm{ft}^{3} / \mathbf{s}\right)\end{array}$ & $\begin{array}{c}\text { Recurrence } \\
\text { interval } \\
\text { (years) }\end{array}$ \\
\hline 1 & $\begin{array}{l}\text { Mauvais Coulee Tributary No. } 3 \text { near Cando, } \\
\text { N. Dak. }(05056060)\end{array}$ & 60.2 & $\begin{array}{l}1955-1973 \\
1986-1988 \\
1989-2008\end{array}$ & $04 / 14 / 1969$ & a9.35 & $04 / 14 / 1969$ & 2,300 & $04 / 14 / 2009$ & b,c 10.42 & $04 / 14 / 2009$ & 1,200 & $10-25$ \\
\hline 2 & Mauvais Coulee near Cando, N. Dak. (05056100) & 387 & $1956-2008$ & $04 / 21 / 1997$ & 11.68 & $04 / 21 / 1997$ & 3,000 & $04 / 15 / 2009$ & 11.57 & $04 / 15 / 2009$ & 2,840 & $5-10$ \\
\hline 3 & $\begin{array}{l}\text { Edmore Coulee near Edmore, N. Dak. } \\
\quad(05056200)\end{array}$ & 382 & $\begin{array}{c}1956 \\
1957-2008\end{array}$ & $04 / 24 / 1997$ & 87.95 & $04 / 24 / 1997$ & 1,830 & $03 / 31 / 2009$ & b88.01 & $04 / 16 / 2009$ & ${ }^{\mathrm{d}} 1,160$ & $5-10$ \\
\hline 4 & $\begin{array}{l}\text { Edmore Coulee Tributary near Webster, N. Dak. } \\
\text { (05056215) }\end{array}$ & 148 & 1986-2008 & $08 / 02 / 1993$ & 75.06 & $04 / 25 / 1997$ & 1,390 & $04 / 19 / 2009$ & 74.29 & $04 / 19 / 2009$ & 1,360 & $5-10$ \\
\hline 5 & Morrison Lake near Webster, N. Dak. (05056222) & 501 & $1985-2008$ & $04 / 27 / 1997$ & 62.60 & na & na & $04 / 21 / 2009$ & 62.61 & na & na & na \\
\hline 6 & $\begin{array}{l}\text { Starkweather Coulee near Webster, N. Dak. } \\
\quad(05056239)\end{array}$ & 310 & 1979-2008 & 04/06/1989 & ${ }^{\mathrm{b}} 10.05$ & $04 / 09 / 2004$ & 908 & $04 / 17 / 2009$ & ${ }^{\mathrm{e}} 8.58$ & $04 / 17 / 2009$ & 978 & $10-25$ \\
\hline 7 & Dry Lake near Penn, N. Dak. (05056241) & 920 & $1983-2008$ & $05 / 02 / 1997$ & 52.02 & na & na & $04 / 27 / 2009$ & 52.62 & na & na & na \\
\hline 8 & $\begin{array}{l}\text { Lake Alice-Irvine Channel near Churchs Ferry, } \\
\text { N. Dak. (05056255) }\end{array}$ & 999 & $\begin{array}{l}1985-1987 \\
1998-2008\end{array}$ & $04 / 19 / 2006$ & 49.93 & na & na & 05/04/2009 & f5 51.41 & na & na & na \\
\hline 9 & Little Coulee near Leeds, N. Dak. (05056340) & 320 & 1998-2008 & 04/13/1999 & 66.41 & 04/23/1999 & 269 & $04 / 19 / 2009$ & 68.61 & $04 / 16 / 2009$ & g395 & $10-25$ \\
\hline 10 & $\begin{array}{l}\text { Devils Lake near Devils Lake, N. Dak. } \\
\quad(05056500)\end{array}$ & 3,130 & $\begin{array}{l}1867-1963 \\
1964-2008\end{array}$ & $05 / 09 / 2006$ & 49.20 & na & na & $06 / 27 / 2009$ & 50.93 & na & na & na \\
\hline 11 & $\begin{array}{l}\text { Devils Lake Outlet to Stump Lake near Lakota, } \\
\text { N. Dak. (05056636) }\end{array}$ & na & 1999-2007 & $05 / 04 / 2006$ & 48.37 & na & na & 07/09/2009 & 51.05 & na & na & na \\
\hline 12 & $\begin{array}{l}\text { Eastern Stump Lake near Lakota, N. Dak. } \\
\quad(05056665)\end{array}$ & na & 1999-2008 & $08 / 11 / 2007$ & 47.64 & na & na & $07 / 15 / 2009$ & 50.68 & na & na & na \\
\hline
\end{tabular}

aDatum then in use.

${ }^{b}$ Backwater from ice, debris, aquatic vegetation, or other water resource.

'From high-water mark.

${ }^{\mathrm{d}}$ Gage height, 87.53 feet

'Recorded value, actual stage may have been higher during period of no gage height, April 9-17.

${ }^{\mathrm{f}}$ May have been higher during period of no record, April 23 to May 4.

${ }^{\mathrm{g}}$ Gage height, 68.44 feet. 


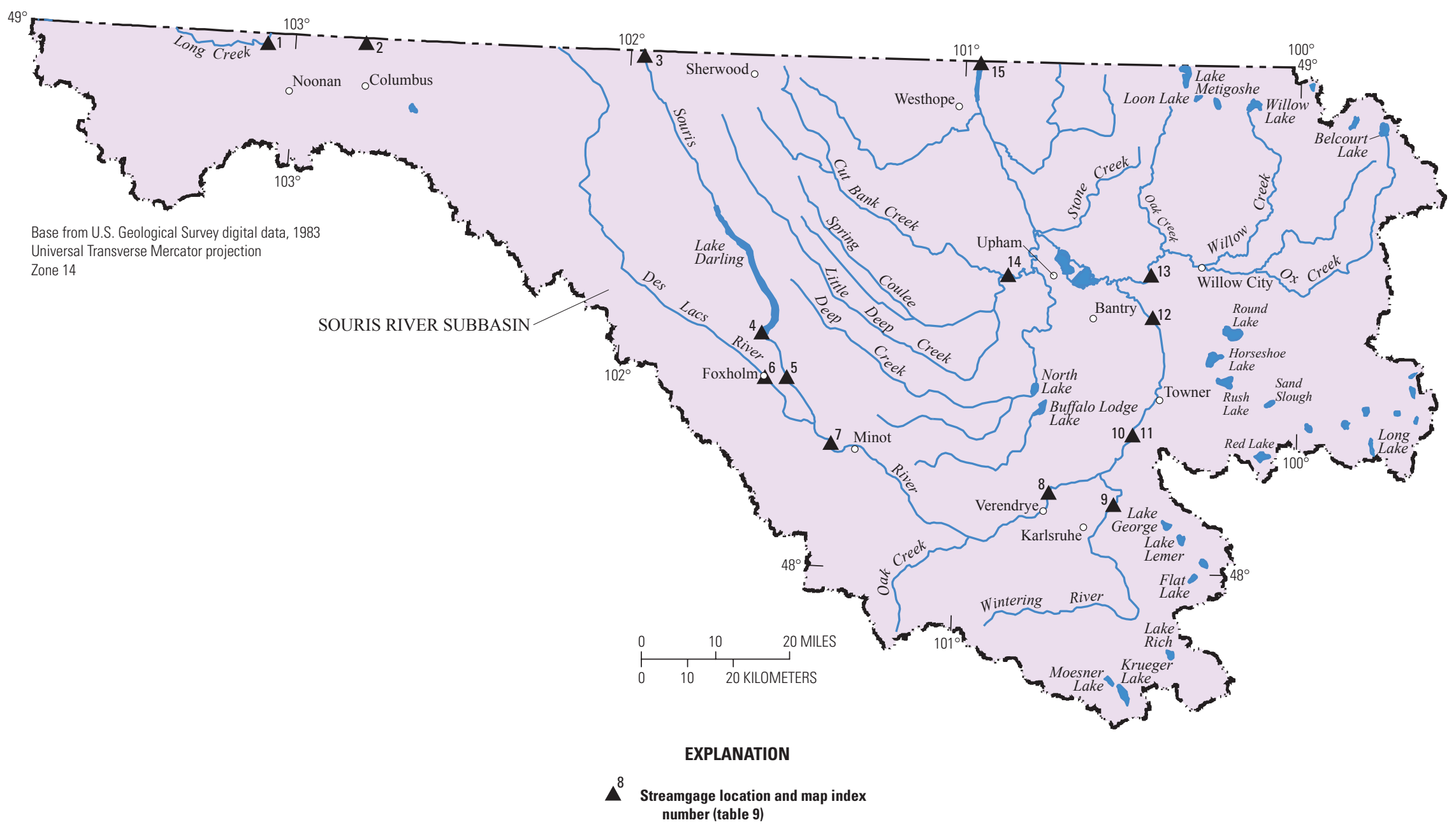

Figure 9. Locations of selected streamgages, rivers, lakes, streams, lakes, and cities in the Souris River subbasin in North Dakota. 
Table 9. Historical and 2009 peak of record stages and discharges for the Souris River subbasin in North Dakota.

[Data and footnotes in this table as well as additional station information can be found by searching on the station (site) number on the table in the U.S. Geological Survey's Water-resources data for the United States, Water Year 2009 accessed on January 2011 at $h t t p: / / w d r$ water.usgs.gov/wy2009/search.jsp. $\mathrm{mi}^{2}$, square miles; ft, feet; f $\mathrm{ft}^{3} / \mathrm{s}$, cubic feet per second; red print, peak of record; na, not available; reg., regulated; $<$, less than]

\begin{tabular}{|c|c|c|c|c|c|c|c|c|c|c|c|c|}
\hline \multirow[b]{2}{*}{$\begin{array}{l}\text { Site } \\
\text { (fig. 9) }\end{array}$} & \multirow[b]{2}{*}{ Station name and number } & \multirow[b]{2}{*}{$\begin{array}{c}\text { Drainage } \\
\text { area } \\
\left(\mathbf{m i}^{2}\right)\end{array}$} & \multicolumn{5}{|c|}{ Maximum peaks previously known from period of record } & \multicolumn{5}{|c|}{ Maximum peaks from March to September 2009} \\
\hline & & & $\begin{array}{l}\text { Period of } \\
\text { known } \\
\text { peaks }\end{array}$ & $\begin{array}{l}\text { Date of } \\
\text { peak } \\
\text { stage }\end{array}$ & $\begin{array}{c}\text { Stage } \\
\text { (ft) }\end{array}$ & $\begin{array}{c}\text { Date of } \\
\text { peak discharge }\end{array}$ & $\begin{array}{l}\text { Discharge } \\
\left(\mathrm{ft}^{3} / \mathbf{s}\right)\end{array}$ & $\begin{array}{c}\text { Date of } \\
\text { peak stage }\end{array}$ & $\begin{array}{l}\text { Stage } \\
\text { (ft) }\end{array}$ & $\begin{array}{c}\text { Date of } \\
\text { peak discharge }\end{array}$ & $\begin{array}{l}\text { Discharge } \\
\left(\mathrm{ft}^{3} / \mathbf{s}\right)\end{array}$ & $\begin{array}{l}\text { Recurrence } \\
\text { interval } \\
\text { (years) }\end{array}$ \\
\hline 1 & $\begin{array}{l}\text { Long Creek near Noonan, N. Dak. } \\
(05113600)\end{array}$ & 1,790 & $1959-2008$ & $03 / 31 / 1976$ & 17.61 & $03 / 31 / 1976$ & 6,310 & $04 / 13 / 2009$ & 13.42 & $04 / 13 / 2009$ & 3,180 & $50-100$ \\
\hline 2 & $\begin{array}{l}\text { East Branch Short Creek Reservoir near } \\
\text { Columbus, N. Dak. (05113750) }\end{array}$ & 280 & $1963-2008$ & 03/28/1976 & 32.13 & na & na & $04 / 13 / 2009$ & 29.75 & 04/13/2009 & na & na \\
\hline 3 & $\begin{array}{l}\text { Souris River near Sherwood, N. Dak. } \\
\quad(05114000)\end{array}$ & 8,940 & $1930-2008$ & $04 / 10 / 1976$ & 25.15 & 04/10/1976 & 14,800 & $04 / 19 / 2009$ & 12.70 & $04 / 19 / 2009$ & ${ }^{\mathrm{a}} 1,350$ & $2-23$ (reg.) \\
\hline 4 & $\begin{array}{l}\text { Lake Darling near Foxholm, N. Dak. } \\
\quad(05115500)\end{array}$ & 9,450 & $1936-2008$ & $04 / 17 / 1976$ & $1,601.24$ & na & na & $06 / 04 / 2009$ & ${ }^{\mathrm{b}} 1,597.58$ & 06/04/2009 & na & na \\
\hline 5 & $\begin{array}{l}\text { Souris River near Foxholm, N. Dak. } \\
\quad(05116000)\end{array}$ & 9,470 & $1936-2008$ & $04 / 17 / 1976$ & 17.17 & $04 / 17 / 1976$ & 8,600 & $04 / 14 / 2009$ & c7.89 & $04 / 18 / 2009$ & $\mathrm{a}, \mathrm{d} 308$ & $<2$ (reg.) \\
\hline 6 & $\begin{array}{l}\text { Des Lacs River at Foxholm, N. Dak. } \\
\quad(05116500)\end{array}$ & 939 & $\begin{array}{l}1904-1906 \\
1945-2008\end{array}$ & $04 / 19 / 1979$ & $\mathrm{e} 21.23$ & 04/19/1979 & 4,260 & $04 / 13 / 2009$ & ${ }^{\mathrm{f}} 18.17$ & 04/13/2009 & a 2,300 & 10-25 (reg.) \\
\hline 7 & $\begin{array}{l}\text { Souris River above Minot, N. Dak. } \\
\quad(05117500)\end{array}$ & 10,600 & 1903-2008 & $04 / 20 / 1904$ & $\mathrm{~g} 21.90$ & $04 / 20 / 1904$ & ${ }^{\mathrm{h}} 12,000$ & $04 / 14 / 2009$ & 14.83 & $04 / 14 / 2009$ & a3,370 & 10-25 (reg.) \\
\hline 8 & $\begin{array}{l}\text { Souris River near Verendrye, N. Dak. } \\
\quad(05120000)\end{array}$ & 11,300 & $1937-2008$ & $04 / 19 / 1976$ & 17.84 & $04 / 19 / 1976$ & 9,900 & $04 / 15 / 2009$ & 17.92 & $04 / 15 / 2009$ & ${ }^{\mathrm{a}} 10,900$ & $100-200$ (reg.) \\
\hline 9 & $\begin{array}{l}\text { Wintering River near Karlsruhe, N. Dak. } \\
(05120500)\end{array}$ & 705 & $1937-2008$ & 04/07/1949 & 12.00 & 04/07/1949 & 3,000 & $04 / 15 / 2009$ & $\mathrm{c}, \mathrm{e} 9.48$ & $04 / 15 / 2009$ & $\mathrm{j} 2,210$ & na \\
\hline 10 & $\begin{array}{l}\text { Souris River west outfall at Eaton Dam } \\
\text { near Towner, N. Dak. (05121000) }\end{array}$ & na & 2004-2008 & $04 / 21 / 2008$ & 6.32 & $04 / 13 / 2008$ & 267 & \multicolumn{5}{|c|}{ No flow diverted past gage. } \\
\hline 11 & $\begin{array}{l}\text { Souris River east outfall at Eaton Dam } \\
\text { near Towner, N. Dak. (05121001) }\end{array}$ & na & $2004-2008$ & $04 / 22 / 2008$ & 8.74 & $04 / 28 / 2007$ & 126 & \multicolumn{5}{|c|}{ No flow diverted past gage. } \\
\hline 12 & $\begin{array}{l}\text { Souris River near Bantry, N. Dak. } \\
\quad(05122000)\end{array}$ & 12,300 & $1937-2008$ & $04 / 23 / 1976$ & 14.59 & $04 / 23 / 1976$ & 9,330 & 04/20/2009 & 14.13 & 04/20/2009 & a7, 070 & 25-50 (reg.) \\
\hline 13 & $\begin{array}{l}\text { Willow Creek near Willow City, N. Dak. } \\
(05123400)\end{array}$ & 1,160 & $1956-2008$ & $04 / 12 / 1969$ & 16.76 & $04 / 12 / 1969$ & 5,900 & $04 / 12 / 2009$ & 14.37 & $04 / 12 / 2009$ & 1,830 & $5-10$ \\
\hline 14 & $\begin{array}{l}\text { Deep River near Upham, N. Dak. } \\
\quad(05123510)\end{array}$ & 975 & $\begin{array}{l}1957-1980 \\
1985-2008\end{array}$ & $04 / 12 / 1969$ & 18.18 & $04 / 12 / 1969$ & 6,760 & $04 / 16 / 2009$ & 13.89 & $04 / 16 / 2009$ & 1,340 & $5-10$ \\
\hline 15 & $\begin{array}{l}\text { Souris River near Westhope, N. Dak. } \\
(05124000)\end{array}$ & 16,900 & $\begin{array}{c}1929 \\
1930-2008\end{array}$ & $04 / 26 / 1976$ & 19.16 & $04 / 26 / 1976$ & 12,600 & 04/30/2009 & ${ }^{\mathrm{k}} 16.18$ & $04 / 30 / 2009$ & $\mathrm{a}, \mathrm{k} 5,700$ & 10-25 (reg.) \\
\hline
\end{tabular}

${ }^{\mathrm{a} A f f e c t e d ~ b y ~ r e g u l a t i o n ~ o r ~ d i v e r s i o n . ~}$

${ }^{\mathrm{g}}$ At site in Minot, maximum stage at present location about 23.00 feet.

${ }^{\mathrm{b}}$ Maximum daily average.

${ }^{\mathrm{h}}$ At site in Minot, from rating curve extended above 8,000 cubic feet per second.

'Backwater due to ice, debris, aquatic vegetation, or other water resources.

iDetermined by velocity-area estimation.

${ }^{\mathrm{d}}$ Gage height, 7.52 feet.

${ }^{j}$ Gage height, 9.31 feet.

${ }^{\mathrm{e}}$ From high-water mark.

${ }^{\mathrm{k}}$ Estimated.

fObserved, may have been higher during period of no record, March 23 to April 14. 


\section{Elevations and Contents of Selected Reservoirs and Lakes}

Flood control is one of the primary functions of many reservoirs and dams in the Northern Plains. The amount of discharge into a reservoir, the volume of water currently being stored in the reservoir, the volume of water that can be stored before a critical state exists, and the types of hydrologic conditions that exist downstream from the reservoir, determine the discharge that can be released from the reservoir without causing a detrimental effect on people and properties downstream.

Many peak stages and discharges on the Missouri, James, Red, and Sheyenne Rivers and other tributaries were affected by releases from the dams. Also evident during the 2009 flooding but not discussed here was the effect of high flows on smaller reservoirs and lakes in the area (North Dakota Water Education Foundation, 2009). During the 2009 spring floods, many smaller reservoirs in the region were at or near storage capacity. Several dams located on smaller rivers and streams needed to be repaired after being breached or washed out because of high flows.

The peak of record, 1997 and 2009 peak elevations, and contents of the selected reservoirs and lakes in the region are listed in figure 10 and table 10. Many of the reservoirs had peak of record elevations or elevations during 2009 that ranked within the top five highest elevations for that reservoir's period of record. For Garrison Dam on the Missouri River, discharge from the dam was reduced to zero for an extended period for the first time since the dam's completion to help alleviate flooding downstream at Bismarck (U.S. Army Corps of Engineers, 2009b). At the Jamestown Dam on the James River, reservoir levels during spring runoff were maintained at peak levels by water resource managers to reduced peak flows downstream from the dam. Rapid deployment gages from the USGS were used in the James River Basin to help officials monitoring flood conditions on the James River and its tributaries. Record releases from Baldhill Dam (site 9, fig. 10, table 10) on the Sheyenne River caused flooding downstream in Valley City and other low-lying areas in the basin. Residents were evacuated as city sewers were inundated and drinking supplies were lost (North Dakota Water Education Foundation, 2009).

At Lake Tschida at Heart Butte Dam (site 2, fig. 10, table 10), the flow from the Heart River and its tributaries caused the water level in the reservoir to come within 3.5 feet of the historical reservoir peak set in 1952. Several recreational trailer homes located along the lake were flooded when the lake level continued to rise in April 2009 (North Dakota Water Education Foundation, 2009).

\section{Summary}

In 2009, record-breaking snowfalls and above-normal spring rainfall caused severe flooding in the Northern Plains of North Dakota, Minnesota, and South Dakota. There were 48 peak of record stages and 36 peak of record discharges recorded at USGS streamgages located in the Missouri River and Red River of the North Basins.

Cities such as Bismarck and Fargo reported several days of record snowfall throughout the winter in addition to recording above-normal amount of rainfall in March. In 2009, Bismarck had the snowiest March on record and Fargo recorded the most precipitation on record for the month of March. Snowfall amounts were above-normal in many locations throughout both basins.

Near Bismarck, ice jams on the Missouri River north and south of the city caused flooding. Southwest Bismarck was evacuated as rising waters first inundated homes along the river and then began flowing into the city's lower south side. On March 24, 2009, the peak stage of the Missouri River at Bismarck, N. Dak. streamgage was $16.11 \mathrm{ft}$. South of Bismarck, at the Missouri River near Schmidt, N. Dak. streamgage, the peak stage was $24.24 \mathrm{ft}$ on March 25, 2009, which surpassed the peak of record of $23.56 \mathrm{ft}$ occurring on December 9, 1976. Although the stage reached record levels at these streamgages, the discharge through the river at these locations did not reach record levels. Backwater from the ice jam south of Bismarck and Mandan flooded the southwest side of Bismarck and displaced residents living in the area.

At the Red River of the North at Fargo, N. Dak. streamgage, the Red River's peak stage of $40.84 \mathrm{ft}$ surpassed the peak of record stage of $39.72 \mathrm{ft}$ set in 1997 by 1.12 inches. Also at Fargo, the peak streamflow of $29,500 \mathrm{ft}^{3} / \mathrm{s}$ exceeded the previous peak of record set in 1997 by $1,500 \mathrm{ft}^{3} / \mathrm{s}$. For the cities of Fargo and Moorhead and the surrounding area, the stage of the Red River remained above the flood stage for nearly 2 months.

In addition to the high stages and discharges on the main-stem Missouri and Red Rivers, peak of record stages and discharges were reached at several USGS streamgages in the Missouri River and Red River Basins. The Little Missouri, James, Sheyenne, Devils Lake, and Souris Rivers all had peak of record stages and discharges occurring in 2009. Rapid deployment gages were used in the James River Basin to help officials monitoring flood conditions on the James River and its tributaries. Also, there were several other tributaries to the Missouri and Red Rivers that recorded peak of record stages and discharges along their reaches. Water did not recede or evaporate from the low-lying areas for several weeks. 


\section{CANADA}

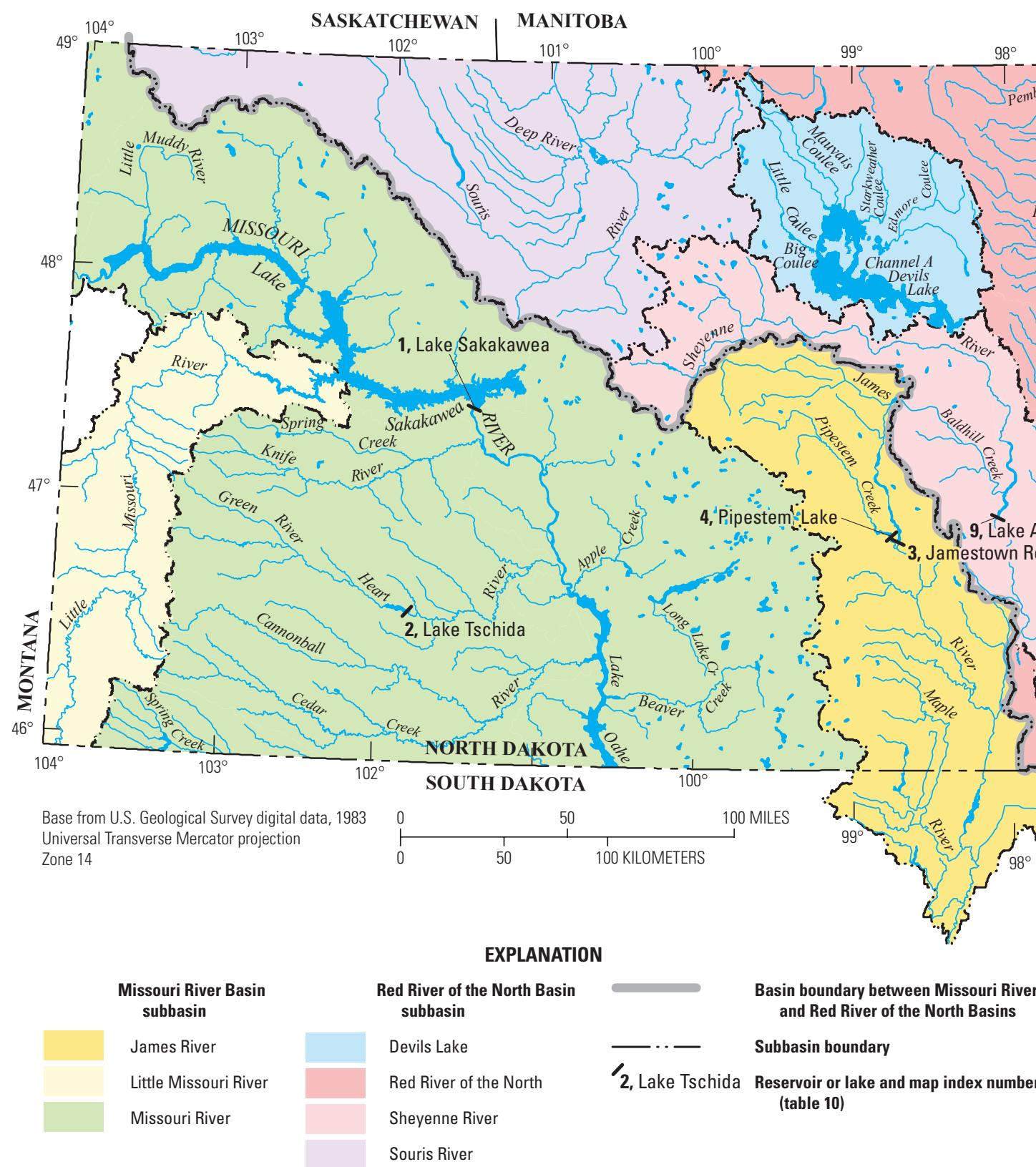

Figure 10. Locations of selected reservoirs and lakes in the Missouri River and Red River of the North subbasins in North Dakota, western Minnesota, and northeastern South Dakota. 
Table 10. Historical, 1997, and 2009 peak elevations of selected reservoirs and lakes in the Missouri River and Red River of the North subbasins of North Dakota, western Minnesota, and northeastern South Dakota.

[Data from the U.S. Geological Survey website accessed January 2011 at http://wdr.water.usgs.gov/wy2009/search.jsp; U.S. Bureau of Reclamation, written commun., 2010; and U.S. Army Corps of Engineers (St. Paul and Omaha Districts), written commun., 2010; 2009 data are considered preliminary pending further analysis; USGS, U.S. Geological Survey; --, unknown; na, not available]

\begin{tabular}{|c|c|c|c|c|c|c|c|c|c|c|c|c|c|}
\hline \multicolumn{8}{|c|}{ Reservoir or lake } & \multicolumn{2}{|c|}{$\begin{array}{c}\text { Historical reservoir } \\
\text { peak }\end{array}$} & \multicolumn{2}{|c|}{1997 reservoir peak } & \multicolumn{2}{|c|}{2009 reservoir peak } \\
\hline $\begin{array}{c}\text { Site } \\
\text { (fig. 10) }\end{array}$ & $\begin{array}{l}\text { USGS } \\
\text { station } \\
\text { number }\end{array}$ & Name (dam) & $\begin{array}{c}\text { Drainage } \\
\text { area } \\
\left(\mathrm{mi}^{2}\right)\end{array}$ & $\begin{array}{c}\text { Year } \\
\text { storage } \\
\text { began }\end{array}$ & $\begin{array}{c}\text { Multi- } \\
\text { purpose pool } \\
\text { (acre-feet) }\end{array}$ & $\begin{array}{c}\text { Flood- } \\
\text { control pool } \\
\text { (acre-feet) }\end{array}$ & $\begin{array}{c}\text { Spillway } \\
\text { elevation } \\
\text { (feet) }\end{array}$ & $\begin{array}{c}\text { Elevation } \\
\text { (feet) }\end{array}$ & Date & $\begin{array}{c}\text { Elevation } \\
\text { (feet) }\end{array}$ & Date & $\begin{array}{c}\text { Elevation } \\
\text { (feet) }\end{array}$ & Date \\
\hline \multicolumn{14}{|c|}{ Missouri River subbasin } \\
\hline 1 & 06338000 & Lake Sakakawea (Garrison) & 181,400 & 1953 & $18,750,000$ & $4,300,000$ & $1,825.00$ & $1,854.60$ & $07 / 25 / 75$ & $1,854.40$ & $07 / 01 / 97$ & $1,842.60$ & 08/--/09 \\
\hline 2 & 06346000 & Lake Tschida (Heart Butte) & 1,710 & 1949 & 75,800 & 147,900 & $2,064.50$ & $2,086.23$ & $04 / 09 / 52$ & $2,082.19$ & $03 / 24 / 97$ & $2,082.73$ & $04 / 17 / 09$ \\
\hline \multicolumn{14}{|c|}{ James River subbasin } \\
\hline 3 & 06469000 & Jamestown (Jamestown) & 1,760 & 1953 & 35,500 & 389,000 & na & $1,444.67$ & $04 / 25 / 96$ & $1,445.90$ & $05 / 02 / 97$ & $1,454.10$ & $04 / 26 / 09$ \\
\hline 4 & 06469820 & Pipestem (Pipestem) & 1,010 & 1973 & 9,870 & 147,000 & na & $1,479.54$ & $05 / 22 / 95$ & $1,481.01$ & 05/10/97 & $1,492.30$ & 04/23/09 \\
\hline \multicolumn{14}{|c|}{ Red River of the North subbasin } \\
\hline 5 & na & Mud Lake (White Rock) & 1,160 & 1942 & 6,500 & b249,500 & 965.00 & na & na & na & na & na & na \\
\hline 6 & na & Lake Traverse (Reservation) & & 1942 & 106,000 & na & 974.00 & 980.34 & $04 / 03 / 95$ & 982.21 & $04 / 16 / 97$ & 980.73 & 04/01/09 \\
\hline 7 & 05045950 & Orwell (Orwell) & 1,820 & 1953 & 8,300 & 14,000 & $1,044.00$ & $1,072.38$ & $05 / 23 / 66$ & $1,070.27$ & $04 / 15 / 97$ & $1,066.72$ & 06/22/09 \\
\hline 8 & 05074000 & Red Lake (Lower Red Lake) & 1,950 & 1931 & $1,810,000$ & $3,270,000$ & $1,169.60$ & $1,178.53$ & $06 / 25 / 50$ & $1,175.85$ & $07 / 18 / 97$ & $1,176.04$ & $05 / 27 / 09$ \\
\hline 9 & 05057500 & Lake Ashtabula (Baldhill) & 7,470 & 1950 & 70,600 & c 85,200 & $1,252.00$ & $1,270.51$ & $04 / 07 / 04$ & $1,267.51$ & $04 / 30 / 97$ & $1,269.43$ & 04/26/09 \\
\hline 10 & na & Homme Lake (Homme) & 229 & 1951 & 2,840 & 6,700 & $1,080.00$ & $1,080.00$ & $04 / 20 / 79$ & $1,083.25$ & $04 / 20 / 97$ & $1,082.40$ & $04 / 14 / 09$ \\
\hline
\end{tabular}

${ }^{a}$ At high discharges, water retained by White Rock Dam backs up over Reservation Dam (Lake Traverse) creating a much larger Lake Traverse.

'Includes Lake Traverse at high discharge.

${ }^{\mathrm{C}}$ Maximum storage is available to about 1,268.30 feet because of limited channel capacity downtream. Surcharge storage is available to 1,273.20 feet or 116,500 acre-feet. According to Ruddy and Hitt (1990), surcharge storage is storage above the total retention level. This storage increase can result from closed spillway gages increasing the dam height and allowing temporary detention of a volume of floodwater above the controllable pool level. 
Several reservoirs in the basins reported record elevations. For Garrison Dam on the Missouri River, discharge from the dam was at zero flow for the first time since the dam's completion. Zero flow was maintained for a period of time to help alleviate flooding downstream at Bismarck. Record releases from Baldhill Dam on the Sheyenne River with additional flow from elsewhere in the basin caused flooding downstream in Valley City. Residents within the city were evacuated as city sewers were flooded and the water supply was threatened.

\section{Acknowledgments}

The authors would like to thank the personnel at the U.S. Geological Survey (USGS) North Dakota, Minnesota, and South Dakota Water Science Centers whose hard work and dedication during the 2009 flooding event helped to collect the data and provide information used in this report. Additional thanks goes to USGS field crews from the following offices for their efforts in collecting data during the flooding: Montana, Minnesota, Nebraska, Iowa, Kansas, Illinois, and Florida.

\section{Selected References}

Bismarck Tribune, accessed January 2011, at $h t t p: / / w w w$. bismarcktribune.com/news/state-and-regional/article f91610e6-e024-11de-a985-001cc4c002e0.html.

Climate of North Dakota, accessed January 2010, at http:// www.npwrc.usgs.gov/resource/habitat/climate/figure $42 . \mathrm{htm}$

Environment News Service, 2009, news release, accessed January 2011 at $h t t p: / / w w w . e n s-n e w s w i r e . c o m / e n s /$ mar2009/2009-03-26-091.html.

Fargo-Moorhead Forum, accessed April 15, 2009, at http:// www.inforum.com/event/article/id/237354/.

Federal Interagency Devils Lake Working Group, 2010, Summary Report, accessed January 2011, at http://asacw.hqda. pentagon.mil/documents/DevilsLakeReportFINAL.pdf, 41 p.

Holmes, R.R., Jr., Koenig, T.A., and Karstensen, K.A., 2010, Flooding in the United States Midwest, 2008: U.S. Geological Survey Professional Paper 1775, 64 p.

Interagency Advisory Committee on Water Data, 1982, Guidelines for determining flood flow frequency: Reston, Virginia, U.S. Geological Survey Bulletin 17B of the Hydrology Subcommittee, Office of Water Data Coordination, $183 \mathrm{p}$.
Macek-Rowland, K.M., 1997, 1997 Floods in the Red River of the North and Missouri River Basins in North Dakota and western Minnesota: U.S. Geological Survey Open-File Report 97-575, 6 p.

Macek-Rowland, K.M., 2000, Suspended-sediment loads from major tributaries to the Missouri River between Garrison Dam and Lake Oahe, North Dakota, 1954-98: U.S. Geological Survey Water-Resources Investigations Report 00-4027, 24 p.

Macek-Rowland, K.M., 2001a, 2001 Floods in the Red River of the North Basin in Eastern North Dakota and Western Minnesota: U.S. Geological Survey Open-File Report 01-169, 8 p.

Macek-Rowland, K.M., Burr, M.J., and Mitton, G.B., 2001b, Precipitation in the Northern Plains, September 1996 through April 1997: U.S. Geological Survey Circular 1185-A, 19 p.

Macek-Rowland, K.M., Burr, M.J., and Mitton, G.B., 2001c, Peak discharges and flow volumes for streams in the Northern Plains, 1996-97: U.S. Geological Survey Circular 1185-B, $52 \mathrm{p}$.

Minnesota Department of Administration, State Demographic Center, accessed January 2010 at $h t t p: / / w w w . d e m o g r a p h y$. state.mn.us/resource.html? Id $=19243$.

Murphy, E.C., Fritz, A.M.K., and Fleming, R.F., 2002, The Jerusalem and Tolna Outlets in the Devils Lake Basin, North Dakota: NDGS Report of Investigation 100, 36 p.

North Dakota Data Census Center, City Census Data, accessed January 2010, at http://www.ndsu.nodak.edu/sdc/data/ census.htm.

North Dakota Monthly Climate Summary, October 2008, accessed January 2010, at http://www.ndsu.edu/ndsco/ publication/ndsco/summary/2008/oct.pdf.

North Dakota Monthly Climate Summary, March 2009, accessed January 2010, at http://www.ndsu.edu/ndsco/ publication/ndsco/summary/2009/mar.pdf.

North Dakota State Water Commission, Devils Lake Factsheet, 2011, accessed March 2011, at http://www.swc. state.nd.us/4dlink9/4dcgi/GetContentPDF/PB-206/ DLFactSheetR.pdf.

North Dakota Water Education Foundation, 2009: North Dakota Water, December 2009, 35p.

Paulson, R.W., Chase, E.B., Roberts, R.S., and Moody, D.W., compilers, 1991, National Water Summary 1988-89Hydrologic events and floods and droughts: U.S. Geological Survey Water-Supply Paper 2375, $591 \mathrm{p}$. 
Red River of the North Flooding - 2006, accessed January 2010, at http://nd.water.usgs.gov/photos/2006RedFlood/ index.html.

Ruddy, B.C., and Hitt, K.J., 1990, Summary of selected characteristics of large reservoirs in the United States and Puerto Rico, 1988: U.S. Geological Survey Open-File Report 90-163, $295 \mathrm{p}$.

U.S. Army Corps of Engineers, 2001, Hydrologic AnalysesThe Red River of the North Main Stem, Wahpeton/Breckenridge to Emerson, Manitoba: Final Hydrology Report, U.S. Army Corps of Engineers, St. Paul District, September $2001,150 \mathrm{p}$.

U.S. Army Corps of Engineers, 2009a, Baldhill Dam, inflow, outflow, pool elevation data, accessed January 2011, at http://www.mvp-wc.usace.army.mil/projects/Baldhill.shtml.

U.S. Army Corps of Engineers, 2009b, Garrison Dam Releases, news release no. 09-009, accessed January 2011, at http://www.nwo.usace.army.mil/html/pa/pahm/ newsreleases2009.htm.

U.S. Army Corps of Engineers, 2009c, EngineerUpdate/ archive2009/09/01, accessed January 2011, at http://www. usace.army.mil/CEPA/EngineerUpdate/archive/2009/09/01/ james-river-flood-fight-in-north-dakota-ends-quietly.aspx.

U.S. Army Corps of Engineers, 2009d, EngineerUpdate/ archive2009/04/30, accessed January 2011, at http://www. usace.army.mil/CEPA/EngineerUpdate/archive/2009/04/30/ omaha-district-joins-north-dakota-flood-fight-1.aspx.

U.S. Army Corps of Engineers, Northwestern Division, news release no. 09-009, aAccessed January 2010, at http://www. nwd.usace.army.mil/pa/news/shownews.asp? rn=09-009.

U.S. Department of Commerce, National Oceanic and Atmospheric Administration, National Environmental Satellite, Data and Information Service, 2009a, Climatological data, Minnesota, July 2009: Asheville, North Carolina, v. 115, no. $7,38 \mathrm{p}$.

U.S. Department of Commerce, National Oceanic and Atmospheric Administration, National Environmental Satellite, Data and Information Service, 2009b, Climatological data, North Dakota, July 2009: Asheville, North Carolina, v. 118, no. 7, 31 p.
U.S. Department of Commerce, National Oceanic and Atmospheric Administration, National Environmental Satellite, Data and Information Service, 1997a, Climatological data, Minnesota, July 1997: Asheville, North Carolina, v. 103, no. $7,52 \mathrm{p}$.

U.S. Department of Commerce, National Oceanic and Atmospheric Administration, National Environmental Satellite, Data and Information Service, 1997b, Climatological data, North Dakota, July 1997: Asheville, North Carolina, v. 106, no. $7,41 \mathrm{p}$.

U.S. Department of Commerce, National Oceanic and Atmospheric Administration, 2009, National Climate Data Center-Snowfall - Average Totals in Inches: Asheville, North Carolina, 7 p, accessed January 2011, at http://lwf. ncdc.noaa.gov/oa/climate/online/ccd/snowfall.html.

U.S. Department of Commerce, National Oceanic and Atmospheric Administration, National Weather Service website, accessed January 2010, at http://www.crh.noaa.gov/product. php site $=N W S \&$ product $=C L M \&$ issuedby $=B I S$.

U.S. Department of Commerce, National Oceanic and Atmospheric Administration, NOAA Satellite and Information Service, Snow and Ice, winter 2008/2009, accessed January 2010, at http://www.ncdc.noaa.gov/oa//climate/ research/2008/snow0809.html\#apr.

U.S. Department of Commerce, National Oceanic and Atmospheric Administration, NOAA Satellite and Information Service, State Drought, October 2008, accessed January 2010, at http://www.ncdc.noaa.gov/img/climate/ research/2008/oct/zin200810_pg.gif.

U.S. Geological Survey, 1991, National Water Summary 1988-89: Hydrologic events and floods and droughts: U.S. Geological Water-Supply Paper 2375, 591 p.

U.S. Geological Survey, 2009, Water Resources Data, North Dakota, Water Year 2009, accessed January 2011, at http:// wdr.water.usgs.gov/wy2009/search.jsp. 


\section{Glossary}

[Note: Glossary terms and definitions are taken from the USGS Annual Data Reports for water resources (in each state), or from Holmes and others (2010).]

Annual Exceedance Probability (AEP) The probability, or chance, of a flood of a given streamflow magnitude being equaled or exceeded in any given year. The probability can be expressed as a fraction, decimal, or percentage.

cubic foot per second $\left(\mathrm{ft}^{3} / \mathrm{s}\right) \quad$ The rate of discharge (flow) representing a volume of 1 cubic foot passing a given point in 1 second. It is equivalent to approximately 7.48 gallons per second or approximately 449 gallons per minute, or 0.02832 cubic meters per second.

discharge (or flow or streamflow) The rate that matter passes through a cross section of a stream channel or other water body per unit of time. The term commonly refers to the volume of water (including, unless otherwise stated, any sediment or other constituents suspended or dissolved in the water) that passes a cross section in a stream channel, canal, pipeline, and so forth, within a given period of time such as in cubic feet per second.

drainage area Area upstream from a stream at a specific location measured in a horizontal plane, which has a common outlet at the site for its surface runoff from precipitation that normally drains by gravity into a stream. Drainage areas given herein include all closed basins, or noncontributing areas, within the area unless otherwise specified.

drainage basin Part of the Earth's surface that contains a drainage system with a common outlet for its surface runoff. (See "Drainage area")

flood peak The highest value of the stage or streamflow attained by a flood; often designated as peak stage or peak streamflow.

flood stage The stage at which overflow of the natural banks of a stream begins to cause damage in the reach in which the water surface is measured.

gage height (G.H.) Height (or elevation) of a water surface above an established datum.
If the water surface is below the gage datum, the gage height is negative. Gage height often is used interchangeably with the more general term "stage," although gage height is more appropriate when used in reference to a reading on a gage.

hydrograph A graph showing stage, streamflow, velocity, or other property of water with respect to time.

peak of record stage (gage height) The highest instantaneous stage (or gage height) value for the period that data have been collected.

peak of record streamflow (discharge) The highest instantaneous streamflow value for the period that data have been collected.

probability A means to express the likelihood of something occurring, also known as chance. The probability can be expressed as a fraction, decimal, or percentage.

rating curve A graph showing the relation between the stage (gage height), usually plotted as the ordinate (X), and amount of water flowing in the channel (streamflow or discharge) expressed as volume per unit time, plotted as the abscissa (Y).

recurrence interval The average interval of time within which the given flood is expected to be equaled or exceeded once at a given location.

stage (gage height) Height (or elevation) of a water surface above an established datum, also known as gage height.

streamflow The discharge that occurs in a natural channel. When used in this report, streamflow uniquely describes the discharge in a surface stream course. The units of measurement often are reported in cubic feet per second $\left(\mathrm{ft}^{3} / \mathrm{s}\right)$.

streamgage A particular site or structure on a stream where a record of streamflow is obtained. 
Publishing support provided by:

Rolla Publishing Service Center

For additional information concerning this publication, contact:

Director, USGS North Dakota Water Science Center

$821 \mathrm{E}$. Interstate Ave.

Bismarck, ND 58503

(701) 250-7400

Or visit the North Dakota Water Science Center Web site at: http://nd.water.usgs.gov 



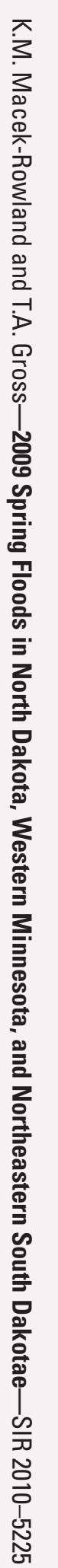

